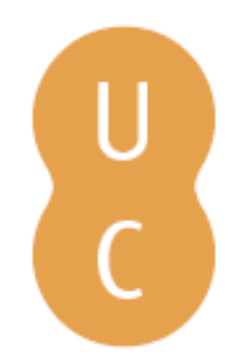

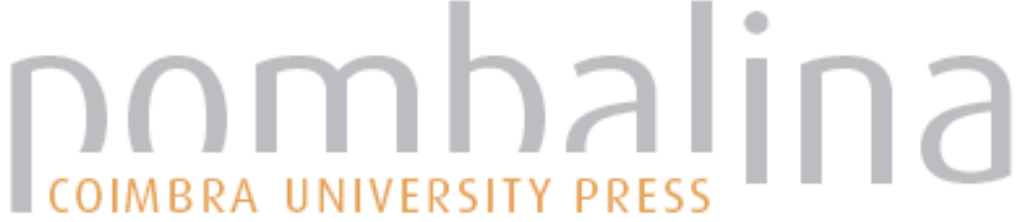

\section{Espaços do pensamento científico da Antiguidade}

Publicado por: Imprensa da Universidade de Coimbra

URL

persistente:

URI:http://hdl.handle.net/10316.2/29938;

DOI: URI:http://hdl.handle.net/10316.2/29938

\section{Accessed : $\quad$ 26-Apr-2023 12:19:26}

A navegação consulta e descarregamento dos títulos inseridos nas Bibliotecas Digitais UC Digitalis, UC Pombalina e UC Impactum, pressupõem a aceitação plena e sem reservas dos Termos e Condições de Uso destas Bibliotecas Digitais, disponíveis em https://digitalis.uc.pt/pt-pt/termos.

Conforme exposto nos referidos Termos e Condições de Uso, o descarregamento de títulos de acesso restrito requer uma licença válida de autorização devendo o utilizador aceder ao(s) documento(s) a partir de um endereço de IP da instituição detentora da supramencionada licença.

Ao utilizador é apenas permitido o descarregamento para uso pessoal, pelo que o emprego do(s) título(s) descarregado(s) para outro fim, designadamente comercial, carece de autorização do respetivo autor ou editor da obra.

Na medida em que todas as obras da UC Digitalis se encontram protegidas pelo Código do Direito de Autor e Direitos Conexos e demais legislação aplicável, toda a cópia, parcial ou total, deste documento, nos casos em que é legalmente admitida, deverá conter ou fazer-se acompanhar por este aviso. 


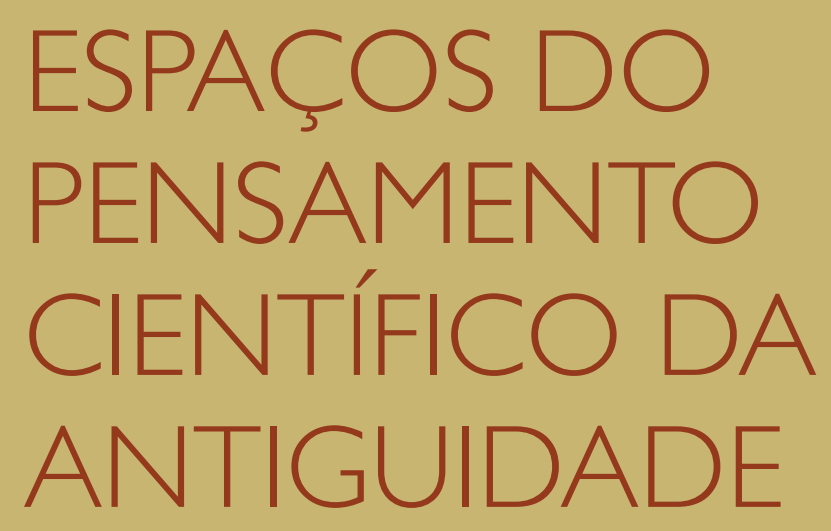

\section{CARMEN SOARES}

\section{COORDENAÇÃO}




\section{CONFERÊNCIAS \& DEBATES INTERDISCIPLINARES corresponde}

a uma coleção destinada a promover a missão prioritária do Instituto de Investigação Interdisciplinar da Universidade de Coimbra, a saber: estimular a investigação avançada, incentivando o cruzamento fértil entre áreas de saber e a agregação de equipas, no sentido de garantir capacidade de afirmação internacional da investigação científica da Universidade de Coimbra. Os volumes que a integram abordam temáticas diversas, unidas por um denominador comum: o diálogo entre diferentes domínios científicos. 
CONFERÊNCIAS

\& DEBATES

INTERDISCIPLINARES

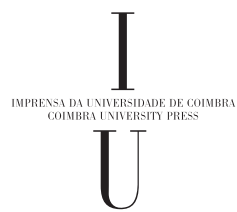




\title{
EDIÇÃo
}

Instituto de Investigação Interdisciplinar da Universidade de Coimbra (IIIUC) Imprensa da Universidade de Coimbra

Email: imprensauc@ci.uc.pt

URL: http//www.uc.pt/imprensa_uc

Vendas online: http://livrariadaimprensa.uc.pt

\section{CORPO EDITORIAL}

Amílcar Falcão (Diretor do IIIUC)

Carmen Soares (Subdiretora do IIIUC)

João Malva (Subdiretor do IIIUC)

\section{CONCEPÇÃO GRÁFICA}

António Barros

\author{
INFOGRAFIA DA CAPA \\ Carlos Costa \\ PAGINAÇ̃o \\ Nelson Henriques \\ EXECUÇÃo GRÁFICA \\ Simões \& Linhares
}

ISSN

2183-1610

ISBN

978-989-26-0743-6

ISBN DIGITAL

978-989-26-0744-3

DOI

http://dx.doi.org/10.14195/978-989-26-0744-3

DEPÓSITO LEGAL

$369018 / 13$

OBRA PUBLICADA COM O APOIO DE:

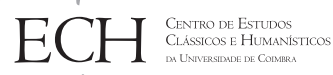




\section{ESPAÇOS DO \\ PENSAMENTO \\ CIENTÍFICO DA \\ ANTIGUIDADE}

\section{CARMEN SOARES}

\section{COORDENAÇÃO}




\section{COMISSÃo CIENTífica}

Alberto Bernabé Pajares (Univ. Complutense de Madrid)

Fábio Souza Lessa (Univ. Federal Rio de Janeiro)

Henrique Leitão (Univ. Lisboa)

Maria do Céu Fialho (Univ. Coimbra)

Maria José García Soler (Univ. País Vasco)

Miguel Ángel González Manjarrés (Univ. Valladolid)

Natália Bebiano Providência e Costa (Univ. Coimbra)

Richard D. McKirahan (Pomona College) 


\section{PREFÁCIO}

A abertura de um Ciclo de Conferências \& Debates Interdisciplinares corresponde a uma iniciativa destinada a promover a missão prioritária do Instituto de Investigação Interdisciplinar da Universidade de Coimbra (IIIUC), a saber: promover a investigação avançada, incentivando o cruzamento fértil entre áreas de saber e a agregação de equipas, no sentido de garantir capacidade de afirmação internacional da investigação científica da UC.

Entendo, ainda, que o IIIUC, enquanto Unidade Orgânica da Universidade de Coimbra, deve pugnar pela promoção do diálogo entre os diferentes saberes, criando pontos de união e contrariando a tendência para a desagregação e a ausência de objetivos partilhados. Este desígnio

é tanto mais necessário, quando a política científica da União Europeia se orienta para a criação de conexões entre a excelência científica, a liderança industrial e os desafios societais.

Começar este Ciclo de "Conferências \& Debates Interdisciplinares" sob o lema "Espaço do pensamento Científico da Antiguidade" é, sem dúvida, reconhecer o muito que temos a aprender com a história e com a acumulação do conhecimento. Fóruns de reflexão como este estarão, seguramente, na génese daquilo que será a capacidade de nos movermos em espaços pouco explorados e, com isso, ganharmos a consciência do muito que temos a fazer em termos de diálogo científico interdisciplinar.

Estou certo de que esta iniciativa do IIIUC irá dar os seus frutos e elevará a interdisciplinaridade para um patamar a que não estamos habituados. Quando nos habituarmos a ver a interdisciplinaridade como uma necessidade e não como uma excentricidade, teremos consolidado a 
abordagem científica do futuro. E é por isso que, cada vez mais, acredito no futuro do Instituto de Investigação Interdisciplinar da Universidade de Coimbra.

Amílcar Falcão

(Diretor do Instituto de Investigação Interdisciplinar da UC) 


\section{FOREWORD}

The initiative of opening a Series of Interdisciplinary Conferences \& Debates meets the major mission of the Institute for Interdisciplinary Research of the University of Coimbra ( IIIUC), namely the promotion of advanced research, by encouraging the crossing of knowledge and team building of different areas, in order to assure international recognition of the UC's scientific research.

It is my understanding that the IIIUC, as an Organic Unit of the University of Coimbra, should strive for promoting the dialogue among different knowledge areas, creating points of union and counteracting the disaggregation tendency and the absence of shared goals. This design is incresingly required as the science policy of the European Union moves towards the creation of connections between scientific excellence, industrial leadership and societal challenges.

Beginning this series of Interdisciplinary Conferences \& Debates on the theme "The Space of Scientific Thought in the Antiquity" definitely recognizes how much we have to learn from History and the accumulation of knowledge. Thinking forums like these will unquestionably represent both the genesis of a capacity to move within unexplored areas and the awareness of how much has to be done in the matter of interdisciplinary scientific dialogue.

I am confident that this initiative of the IIIUC will bear fruit and raise interdisciplinarity to a level we are not yet aware of. As soon as we get accustomed to see interdisciplinarity as a necessity and not as a whimsical, the scientific approach to the future will be consolidated. And that is why my belief in the future of the Institute for 
Interdisciplinary Research of the University of Coimbra strengthens more and more.

Amilcar Falcão

(Director of the Institute for Interdisciplinary Research of the UC) 


\section{SUMÁRIO}

Prefácio.

Foreword

Notas sobre os autores.

Matrizes clássicas gregas da História da Dieta: contributos da tratadística hipocrática

Classical Greek Rots in the History of Diet: Contributions of some Hippocratic Treatises...... 13

Carmen Soares

Os Números e a Natureza do Mundo no Pitagorismo Antigo

Numbers and the Nature of the World in Ancient Pythagoreanism

Gabriele Cornelli

Diofanto de Alexandria e os Primórdios da Álgebra

Diophantus and the Beginnings of Algebra

Carlos Gamas

Dioscórides renovado pela mão dos humanistas: os comentários de Amato Lusitano Dioscorides Renewed by the Humanists: Amato Lusitano's Commentaries 71 António Manuel Lopes Andrade

Bibliografia

Index locorum. 95

Index nominvm 97 
(Página deixada propositadamente em branco) 


\section{NOTAS SOBRE OS AUTORES}

Carmen Soares é Professora da Universidade de Coimbra (Faculdade de Letras). Tem desenvolvido a sua investigação, ensino e publicações nas áreas das Culturas, Literatura e Línguas Clássicas, da História da Grécia Antiga e da História da Alimentação na Antiguidade. É coordenadora executiva do curso de mestrado em "Alimentação - Fontes, Cultura e Sociedade" e directora do mestrado em Estudos Clássicos.

CV disponível na plataforma DeGóis: http://www.degois.pt/visualizador/curriculum. jsp?key=7724126685525965

Gabriele Cornelli é Professor da Universidade de Brasília (Departamento de Filosofia), onde lecciona Filosofia Antiga, é orientador no Programa de Mestrado em Filosofia, Coordenador dos Mestrado e Doutorado em Bioética e do Núcleo de Estudos Clássicos (NEC). Editor da revista Archai (www.archai.unb.br/revista), dirige a Cátedra UNESCO Archai: as origens do pensamento ocidental (www.archai.unb.br) e o GT-Platão e Platonismo da ANPOF. É membro-fundador da International Association for Presocratic Studies e Presidente da International Plato Society (20132016 - platosociety.org). É Professor Visitante do Departamento de Ancient Studies da University of Stellebosch (África do Sul).

CV disponível na plataforma Lattes: http://lattes.cnpq.br/4547907128459717

Carlos Gamas é Professor da Universidade de Coimbra (Departamento de Matemática). Tem repartido a sua docência entre as disciplinas de Análise Matemática, Álgebra Linear e Geometria Analítica. Orientou vários núcleos de estágios pedagógicos. Os seus interesses, na investigação, são, prioritariamente, Álgebra Linear, mas também História da Matemática na Antiguidade e Islão. 
António Andrade é Professor da Universidade de Aveiro (Departamento de Línguas e Culturas).Tem leccionado disciplinas no âmbito das Línguas e Literaturas Latina e Portuguesa e da História das Ciências. Tem desenvolvido a sua investigação sobretudo no âmbito do Humanismo Renascentista Português, da Literatura Novilatina, da História dos Judeus Portugueses e da História das Ciências. Coordena o projecto de I\&D "Dioscórides e o Humanismo Português: os Comentários de Amato Lusitano", financiado pela Fundação para a Ciência e a Tecnologia (http://amatolusitano.web.ua.pt).

CV disponível na plataforma DeGóis: http://www.degois.pt/visualizador/curriculum. jsp?key=0909380718708880 


\title{
MATRIZES CLÁSSICAS GREGAS DA HiSTóRIA DA DIETA: CONTRIBUTOS DA TRATADÍSTICA HIPOCRÁTICA
}

\author{
Classical Greek Rots in the History of Diet: \\ Contributions of some Hippocratic Treatises
}

Carmen Soares

Universidade de Coimbra

\begin{abstract}
RESUMO
O presente estudo visa sintetizar, com base nos tratados hipocráticos Da dieta e Dos padecimentos, os fundamentos da dietética grega antiga. Centramos a nossa investigação em perspectivas de abordagem que continuam actuais, a saber: ciência e divulgação; saúde e sociedade; nutrição e terapêutica; saúde, cultura e meio ambiente. Particular atenção é dedicada aos catálogos de alimentos de ambas as obras, pelo contributo que trazem também para a História da Alimentação, bem como à identificação de regimes condicionados por factores ambientais (as dietas sazonais).
\end{abstract}

PAlaVRaS-Chave: Dieta, alimentação, tratados hipocráticos, história da alimentação, história da medicina, Da dieta, Dos padecimentos

\section{Abstract}

This study aims to synthesize the foundations of the ancient Greek diet based on the Regimen and Affections treatises. We focus our research under the perspective of current approaches, namely: science and dissemination; health and society; nutrition and therapeutics; health, culture and environment. Particular attention is devoted to food catalogs of both works, to their contribution to Food History, as well as to the identification of regimens that are conditioned by environmental factors (the so called seasonal diets).

KEY-WORDS: Diet, food, Hippocratic treatises, food history, history of medicine, Regimen, Affections 


\section{INTRODUÇÃO}

De uso banalizado nos diversos idiomas modernos, o termo "dieta" está hoje reduzido, no seu conteúdo, a uma acepção que desvirtua, em absoluto, a riqueza semântica originalmente contida no étimo grego. Um primeiro esclarecimento, de natureza conceptual, impõem-se, quando nos propomos encetar uma discussão sobre as origens da dietética como ciência. Ou seja, o objecto de estudo do saber em questão são as condições naturais (humanas e ambientais) e culturais que influenciam o bem estar físico e psíquico do ser humano.

$\mathrm{Na}$ verdade, de um sentido genérico, atestado nas fontes gregas desde Homero, que faz corresponder ao termo diaita a tradução 'modo de vida' (determinado por alimentação, habitat, vestuário e costumes), evolui-se, no âmbito dos escritos médicos, para sentidos técnicos, que se podem agrupar naquilo que propomos chamar "domínios fundamentais" e "domínios complementares"1. As acepções estruturantes de "dieta" são três: comida, bebida e exercício físico ${ }^{2}$. Complementam-nas outros quatro âmbitos, a saber: banhos, actividade sexual, repouso (sono e morfologia do leito) e ocupação do tempo (trabalho e ócio).

Definido o domínio epistemológico da presente investigação, há que esclarecer as fontes a que recorremos. Considerando que a temática da dietética se encontra disseminada por numerosos tratados hipocráticos ${ }^{3}$, seleccionámos duas obras que apresentam a vantagem de oferecerem os mais antigos catálogos científicos de alimentos, Da dieta e Dos padecimentos, contributos literários incontornáveis para se construir uma

\footnotetext{
${ }^{1}$ Sobre os sentidos de diaita e correlatos nos autores gregos, vd. Thievel 2000, Jouanna 2008 e 2012.

2 Note-se que, apesar de os Gregos disporem de e de usarem um termo para designar conjuntamente "comida" e "bebida" (trophe), correspondente ao nosso substantivo "alimentação", a verdade é que, da leitura dos trechos agora considerados do corpus hippocraticum sobre regimes alimentares (Da dieta 40-85; Dos padecimentos 39-61), as duas componentes são consideradas distintamente (vd. e.g. infra tradução de Da dieta 1.2.2).

3 Dos cerca de 60 tratados médicos hipocráticos aqueles em que a temática da dietética predomina são os seguintes: Da dieta na saúde, Da dieta nas doenças agudas, Do uso de líquidos, Do alimento. Sobre a dietética no corpus hippocraticum, vd. Craik 1995a, Smith 1980 e 1992, Jouanna 2012.
} 
História da Alimentação ocidental. Desta forma conjugamos, sob o signo da História da Dieta, o estudo de duas áreas de investigação que, de um modo geral, só mais recentemente têm vindo a emergir no domínio dos estudos lusófonos da Antiguidade Clássica, a História da Medicina e a História da Alimentação.

\section{Dietética: ÁREA DE CONHECIMENTO E INTERVENÇÃo PRIMORDIAIS DA MEDICINA ANTIGA}

No tratado em que se faz uma história da medicina antiga (Da Medicina Antiga 3), percebemos de imediato que a dietética é tida como a área genesíaca da ciência médica em geral. Na verdade, os mais antigos médicos perceberam que o primeiro potencial factor de agressão para o corpo são os alimentos que os pacientes ingerem. No fundo, foi de forma natural que a dietética se assumiu como matriz da medicina, a partir da tomada de consciência de que os doentes requeriam uma diaita diversa da das pessoas saudáveis.

Vejamos como, de forma lapidar, o autor do Da dieta coloca o foco da acção do médico nesse domínio da ciência médica. Como se lê em \$2.2, saúde (bygieia) e doença (nousos) são estados que resultam do peso relativo que no regime dos indivíduos assumem a nutrição e o exercício físico:

Realmente alimentos e exercícios têm dinâmicas (dynamiai) opostas, mas contribuem ambos para a saúde: enquanto os exercícios produzem a destruição dos excedentes, os alimentos e as bebidas repõem as perdas.

(Da dieta)

Ou seja, a alimentação responde às necessidades que o corpo tem de nutrientes, ao passo que os exercícios ajudam o corpo a alcançar o equilíbrio físico, pois combatem os excessos acumulados através da assimilação.

Importa salvaguardar que esta consciência de que o bem estar físico está intimamente ligado à dieta alimentar e ao exercício físico, interrelação na contemporaneidade bastante apregoada, circulava nos meios 
intelectuais dos sécs. V-IV a.C. (Craik 1995b: 389), mas coube aos autores hipocráticos dar-lhe forma escrita de fundamento científico.

Completamente inovadora, face à tradição vigente, é, no entanto, a forma como os estudos de dietética permitiram aquilo que o autor do tratado em apreço qualificou de 'descoberta fabulosa' (exeurema kalon), a saber: a prevenção das doenças - ainda hoje uma das vertentes mais valorizadas e preconizadas pela medicina (a chamada medicina preventiva). A essa intervenção preventiva, chama o tratadista "prodiagnóstico", como se depreende do passo Da dieta 69.2:

Há o prodiagnóstico, antes de se adoecer, e o diagnóstico do que está a sofrer o corpo: ou é a alimentação que prevalece sobre os exercícios, ou os exercícios sobre os alimentos ou estão equilibrados entre si. A verdade é que as doenças nascem da prevalência de qualquer um desses dois factores, ao passo que a saúde resulta do equilíbrio entre ambos.

A noção de equilíbrio (metron), acima destacada, sendo transversal ao pensamento grego nos mais diversos domínios (filosofia, ética, política, escultura, arquitectura, entre outros), corresponde, no contexto do discurso médico, e como acabamos de perceber, à definição de saúde.

Embora seja, à luz dos conhecimentos médicos actuais e até no contexto geral do corpus hipocrático, demasiado redutora esta definição de saúde/doença, ela tem para o estudioso da História da Dieta a vantagem de possibilitar aquela que é a primeira reflexão pormenorizada sobre dietética no Mundo Antigo.

\section{SEGMENTOS REFLEXIVOS MATRICIAIS DA DIETÉTICA}

Porque as perspectivas de abordagem da dietética são numerosas, decidi desenvolver aquelas que continuam a transmitir preocupações actuais: 


\section{a) Ciência e Divulgação}

Procuraremos averiguar se os destinatários da ciência publicada (isto é, tornada pública ou divulgada) são apenas a classe profissional dos médicos ou se também, à imagem do que sucede nos nossos dias, se visava um público-alvo mais generalista.

b) Saúde e Sociedade

Considerar se há algum tipo de diferenciação social no acesso da população aos conhecimentos/serviços médicos, o que permite estabelecer uma tipologia diferenciada de pacientes.

c) Nutrição e Terapêutica

A análise dos catálogos de alimentos serve para identificar as propriedades dos alimentos e os seus efeitos sobre o organismo. A noção básica subjacente é a de que os alimentos conservam ou restituem a saúde, ou seja, estão forçosamente presentes na terapêutica a aplicar aos pacientes.

d) Saúde, Cultura e Meio Ambiente

Os tratados autorizam a identificação de dietas tipo, com base nas informações nutricionais e terapêuticas fornecidas sobre alimentos, sua preparação e formas de consumo, associadas a recomendações de exercício físico. Além dos aspectos que têm a ver com a própria natureza (dos alimentos, dos indivíduos), os regimes são condicionados por factores culturais (hábitos e práticas alimentares) e ambientais (geografia e clima).

Note-se que perpassam da reflexão sob os prismas das alíneas c) e d) considerações relativas à práxis médica e à culinária. Por um lado, é possível detectar informações sobre a forma de o médico actuar e princípios norteadores do seu desempenho clínico. Pelo outro, porque as propriedades dos alimentos são modificadas através da intervenção da arte de cozinhar, deparamos, aqui e ali, com referências a formas de confecção e princípios básicos da arte culinária. 
Atentemos, de forma mais desenvolvida, em cada uma das alíneas de análise propostas.

\section{a) Ciência e Divulgação}

Ao considerarmos os destinatários verbalizados pelos autores dos tratados Da dieta e Dos padecimentos, verificamos que visavam públicos distintos ${ }^{4}$. Assim, na abertura do primeiro ( $\$ 2$ ), torna-se claro que a obra foi escrita para médicos, pois aí se enunciam os fundamentos principais da dietética, que aqueles devem conhecer:

- a constituição do corpo humano (physis);

- as propriedades (dynameis) dos alimentos (tanto em estado natural, como confeccionados);

- as propriedades (dynameis) dos exercícios/esforços físicos (ponoi);

- os factores humanos e ambientais que condicionam o equilíbrio saudável entre alimentação e exercício.

Mais, perante a inevitabilidade de os médicos controlarem, permanentemente, a dieta dos seus pacientes, o autor revela-lhes a sua descoberta, a medicina preventiva, ensinando-os, com a descrição de 15 casos clínicos concretos (\$70-84), a identificar sintomas e a conhecer as terapêuticas dietéticas a aplicar.

No tratado Dos padecimentos (§1), por sua vez, deparamos com uma afirmação inequívoca de que esta é uma obra de divulgação, dirigida não a profissionais, mas a leigos. A vantagem de tornar acessível a camadas da população mais esclarecidas conhecimentos básicos sobre a interferência da alimentação no seu estado de saúde residiria no intuito de aumentar a vigilância contra o avanço das doenças.

\footnotetext{
${ }^{4}$ Aliás, o perfil heterogéneo dos numerosos tratados do corpus hippocraticum permitiu a J. Jouanna (1995: 34) estabelecer quatro grupos distintos de obras. Assim, há os textos que correspondem a conferências, inicialmente proferidas diante de um público composto tanto por especialistas como por leigos (rubrica em que se insere o Dos padecimentos), outros que foram redigidos para serem publicados e destinam-se exclusivamente a médicos (caso do $\mathrm{Da}$ dieta) e ainda as notas, inicialmente reservadas ao uso interno de alunos e mestres de medicina, bem como as compilações de tratados perdidos ou conservados, colectâneas que constituem verdadeiros manuais.
} 
Se os não-profissionais estiverem na posse de conhecimentos mínimos sobre o combate às maleitas, mais inofensivas ou em estádio embrionário, podem, aos primeiros sinais, tentar corrigir a sua dieta, além de que estarão mais informados para dialogarem com o médico sobre os padecimentos que os afligem.

Em suma, podemos pressupor que, desde os seus primórdios, a ciência médica esteve atenta ao contributo que os pacientes dariam para o sucesso do exercício do médico, bem como ao cuidado de escrever obras de divulgação a eles destinadas.

\section{b) Saúde e Sociedade}

Se tivermos em linha de conta que os dois pilares da saúde são a alimentação e o exercício físico, e contextualizarmos essa realidade de acordo com os padrões dos sécs. V e IV a.C., compreendemos por que razão o autor do $D a$ dieta (58-59) estabelece uma distinção inicial entre regimes destinados a uma elite (abastada e ociosa) e regimes para as massas (remediadas e trabalhadoras). O argumento de fundo para semelhante discriminação social é de que só quem possui uma fortuna pessoal que o dispense de trabalhar para viver pode zelar pela preservação da sua saúde.

$\mathrm{Na}$ verdade, diferentemente das gentes que trabalham para sobreviver, a minoria rica não se sujeita a uma exposição a todos os elementos perturbadores do equilíbrio entre alimentação e exercício físico (mudanças climatéricas, de residência e de hábitos alimentares/físicos, decorrentes das deslocações a que obrigam determinadas profissões).

Consciente de que a disponibilidade destes dois grandes grupos de pacientes para cuidar da sua dieta é bastante díspar, mas empenhado em cobrir um espectro o mais alargado possível de potenciais doentes inevitavelmente, mais tarde ou mais cedo, a falta de saúde a todos atinge - o tratadista oferece às massas conselhos dietéticos mais generalistas (segundo uma tipologia de quatro dietas sazonais - Inverno, Primavera, Verão e Outono).

Por outro lado, reserva aos privilegiados (da fortuna e de uma saúde, à partida, menos sujeita a riscos, porque condicionada por factores que 
a abastança permite custear: o comer e o tempo livre para a prática de exercício físico) uma panóplia de normativas dietéticas vocacionadas para a reposição do equilíbrio entre alimentação e treino físico, perante quadros clínicos bastante particularizados.

\section{c) Nutrição e Terapêutica}

Importa começar por resumir, brevemente, os princípios básicos da nutrição hipocrática. Os alimentos têm naturezas/constituições (physeis) diversas (fria/quente, húmida/seca) e, decorrentes dessas, outras tantas propriedades (dynameis) fundamentais (arrefecer/aquecer, humedecer/ secar) e mais aquelas que se relacionam com os principais efeitos terapêuticos relativos à função digestiva do organismo humano. Uma vez que esta termina na evacuação dos excedentes (sólidos e líquidos), as propriedades mais assinaladas são as que permitem qualificar os alimentos de 'adstringentes', 'laxantes' e 'diuréticos' (Da dieta 39.2).

As informações contidas nessas listas de alimentos interessam tanto ao estudioso de história da medicina como ao de história da alimentação, pois, como observa o escritor do Da dieta (\$39. 1), a submissão dos alimentos a técnicas de transformação (i.e. à cozinha) altera as propriedades que tinham em estado natural (\$56.2). Daí que, embora as questões culinárias não sejam uma preocupação dos dietistas hipocráticos, elas acabam por aflorar, muito por força da necessidade de identificar alterações nutricionais produzidas graças à intervenção humana na preparação das comidas.

Passemos a uma análise comparativa entre os dois catálogos de alimentos fornecidos pelos tratados hipocráticos ${ }^{5}$. Uma primeira diferença deriva, a meu ver, do público visado por cada uma das obras. Refiro-me ao facto de, no texto escrito para profissionais, serem quase imperceptíveis as alusões a indicações de teor culinário, ao passo que, na obra teoricamente destinada a leigos, a semântica do gosto e da cozinha ganharem maior expressão. Porque não temos tempo de ser exaustivos, limitar-nos-emos a apontar algumas ideias-chave.

\footnotetext{
5 Para uma abordagem deste tipo, cf. Smith 1980.
} 
Na perspectiva do médico, cozinhar é simplesmente uma espécie de pré-digestão, pois o fogo tem sobre os alimentos uma acção idêntica à do estômago. A confecção dos alimentos é, por conseguinte, uma recomendação que o médico faz, por considerar que, no geral, os alimentos crus são mais agressivos $(\$ 56.8)^{6}$.

Por outro lado, na apresentação do catálogo destinado a um público não especializado (Dos padecimentos), valoriza-se sobretudo as formas de preparar os alimentos, tendo em vista harmonizar, dentro do possível, os benefícios terapêuticos resultantes da sua ingestão com os gostos e hábitos alimentares dos doentes. Assim a lista organiza-se segundo uma lógica de regimes alimentares tipificados de acordo com os fins terapêuticos almejados.

Já no catálogo escrito a pensar na actuação dos médicos, que aparece no Da dieta, o leitor é confrontado com uma apresentação dos alimentos por espécie, sendo que, a propósito de cada uma, se referem as suas propriedades medicinais. Atentemos, ainda que de um modo forçosamente exemplificativo, na estrutura e alguns conteúdos de cada um dos catálogos.

\section{Catálogo de alimentos do Da dieta (§ 40-55)}

Do ponto de vista dos itens contemplados, convém notar que se estabelece o primeiro cânone da hierarquia dos alimentos, que obedece à seguinte ordem: cereais; leguminosas; carnes (de quadrúpedes); aves; pescado; ovos; queijo; bebidas; mel; legumes e plantas aromáticas; fruta.

Se o destaque dado ao gado bovino, na rubrica dos quadrúpedes, poderá ser, sobretudo, um reflexo do lugar de prestígio que esses animais tinham na mesa sacrificial dos grandes festivais religiosos públicos ${ }^{7}$, pensamos que o facto de se colocar o pescado antes dos legumes, aqueles que seriam,

\footnotetext{
${ }^{6}$ Há naturalmente excepções, que abrangem a fruta. Curioso será, porém, notar que, se bem que, de um modo geral, o lugar desta fosse no termo da refeição, se recomende que a fruta fresca (por oposição à seca, ao que se deduz) e a de casca dura (do tipo da noz, ao que supomos) se comessem em jejum, de forma a potenciar a assimilação das suas substâncias (Dos padecimentos 61).

${ }^{7}$ Cf. Wilkins 2005: 125, que atribui a explicação dessa mesma proeminência a motivos religiosos.
} 
a par do pão/cereais, os produtos consumidos em maior quantidade, se deverá prender com critérios de natureza dietética e não culinária.

Em favor desta tese temos a distinção que no tratado Dos padecimentos se faz entre alimentos mais nutritivos e promotores da saúde (desde que usados na altura e na quantidade convenientes, §50) e alimentos sem essas propriedades, por isso chamados de 'pobres' (asthenea).

Da primeira categoria fazem parte, precisamente, as comidas e as bebidas que abrem a lista do Da dieta: o pão de trigo e o pão de cevada (entram na rubrica dos cereais), a carne, o peixe, o vinho e a água (bebidos conjuntamente $)^{8}$. Ou seja, talvez por serem considerados de inferior valor nutricional, os legumes e as frutas viram-se relegados para o final do catálogo do Da dieta. Claro que o facto de, por regra, a fruta ser consumida no final da refeição pode ter também contribuído para esse posicionamento?.

O denominador comum a todas as "entradas" do catálogo é o cuidado em indicar tanto as suas propriedades naturais como as artificiais (i.e, as resultantes do cozinhar dos alimentos). Complementarmente são fornecidos dados sobre o ecossistema, a fisiologia, as patologias que combatem ou estimulam (pois os alimentos têm tanto efeitos curativos como agressores da saúde), bem como indicadores de hierarquias de valorização dentro de uma categoria.

Passo a concretizar algumas dessas perspectivas através do exemplo das carnes e derivados ( $\$ 46-51)$.

\section{CARNES E DERVIVADOS 10}

O quadro a seguir apresentado deve ler-se na horizontal (para uma mesma categoria) e na vertical (porque o autor compara categorias) ${ }^{11}$.

\footnotetext{
8 Cf. Dos padecimentos 50 e 61.

9 Galeno alterará o cânone hipocrático, colocando os vegetais e outras plantas imediatamente a seguir aos cereais e deixando para o fim as carnes e derivados, hierarquia esta mais ajustada ao relevo que os mesmos alimentos tinham no regime alimentar dos Gregos e Romanos antigos em geral.

10 Impõe-se um esclareciemnto prévio à leitura do quadro, a saber: o que em linguagem médica se designa por constituição 'seca' e 'húmida' do corpo dos animais corresponde, em linguagem culinária, à indicação de que a carne é 'magra' e 'gorda'.

11 As sinalefas usadas devem ser interpretadas da seguinte forma: + significa 'mais'; = significa 'equivalente a', 'o mesmo que'; / significa 'ou'; => significa 'consequentemente'.
} 


\begin{tabular}{|c|c|c|c|c|}
\hline Categoria & Nome no texto & Propriedades & Ecossistema & Fisiologia \\
\hline $\begin{array}{l}\text { Bovinos } \\
(\$ 46)\end{array}$ & Vaca/vitela & $\begin{array}{l}\text { Pesada, } \\
\text { adstringente, } \\
\text { difícil digestão }\end{array}$ & $\begin{array}{l}\text { Constituição } \\
\text { condicionada }\end{array}$ & $\begin{array}{l}\text { Carne da } \\
\text { cria+tenra }(\S 46)\end{array}$ \\
\hline $\begin{array}{l}\text { Ovinos } \\
(\S 46)\end{array}$ & $\begin{array}{l}\text { Ovelha/ } \\
\text { cordeiro }\end{array}$ & + leve que vaca & $\begin{array}{l}\text { pelo habitat, } \\
\text { alimentação, } \\
\text { idade, sexo, cor } \\
\text { (§49): }\end{array}$ & $\begin{array}{l}\text { Partes do corpo } \\
+ \text { secas }(\S 49)=\text { as } \\
+ \text { exercitadas, + } \\
\text { irrigadas, sobre as } \\
\text { quais os animais } \\
\text { dormem }\end{array}$ \\
\hline $\begin{array}{l}\text { Caprinos } \\
(\$ 46)\end{array}$ & Cabra/cabrito & $\begin{array}{l}\text { + leve que vaca } \\
\text { e ovelha=>+ } \\
\text { laxante }\end{array}$ & $\begin{array}{l}\text { + seca (animais } \\
\text { criados nas } \\
\text { pastagens, os } \\
\text { selvagens }{ }^{12} ; \\
\text { comem feno, } \\
\text { comem muito, } \\
\text { comem fruta, } \\
\text { bebem pouca } \\
\text { água; adultos; } \\
\text { machos; } \\
\text { castrados; } \\
\text { negros; com } \\
\text { pêlo) }\end{array}$ & $\begin{array}{l}\text { Partes do corpo } \\
+ \text { húmidas } \\
(\S 49)=\text { contrário } \\
\text { das anteriores } \\
\text { (cérebro, } \\
\text { medula, cabeça, } \\
\text { pés, genitais e } \\
\text { tendões) }^{13}\end{array}$ \\
\hline \multirow[t]{3}{*}{$\begin{array}{l}\text { Suínos } \\
(\S 46)\end{array}$} & Porco/leitão & + pesada & $\begin{array}{l}\text { + húmida } \\
\text { (animais criados } \\
\text { em curral e os } \\
\text { domésticos; } \\
\text { contrários dos } \\
\text { secos) }\end{array}$ & $\begin{array}{l}\text { Carne do } \\
\text { adulto+tenra }\end{array}$ \\
\hline & $\begin{array}{l}\text { Burro/ } \\
\text { cria }(\$ 46)\end{array}$ & laxante & & $\begin{array}{l}\text { Carne da } \\
\text { cria+laxante }\end{array}$ \\
\hline & Cavalo(\$46) & +laxante & & \\
\hline
\end{tabular}

12 A prática de exercício e a exposição ao clima, tal como sucede com as pessoas, contribui para um corpo mais seco (leia-se musculado).

13 É neste $§ 49$ e não no anterior, dedicado ao pescado, que o autor identifica as partes gordas e magras, na sequência do que faz para o gado. Assim, o lombo é mais seco, a zona abaixo do estômago a mais leve e a cabeça a mais húmida (por aí estar a gordura e o cérebro). Que esta distinção fazia parte de um conhecimento empírico generalizado, confirmam-no algumas das considerações deste tipo, presentes no guia gastronómico de Arquéstrato, cujo receituário já traduzimos e publicámos (Soares 2012, cf. frg. 13 - "Dourada grelhada" e frg. 46 - "Barbudo e robalo grelhados"). 


\begin{tabular}{|c|c|c|c|}
\hline & $\begin{array}{l}\text { Cão/cachorro } \\
(\S 46)\end{array}$ & $\begin{array}{l}\text { Seca, aquece, } \\
\text { fortalece/ } \\
\text { húmida, laxante, } \\
\text { +diurética }\end{array}$ & \\
\hline Caça (\$46) & $\begin{array}{l}\text { Javali } \\
\text { Veado } \\
\text { Lebre } \\
\text { Raposa } \\
\text { Ouriço }\end{array}$ & $\begin{array}{l}\text { Seca, fortalece, } \\
\text { laxante } \\
\text { Seca, diurética } \\
\text { Seca, } \\
\text { adstringente, } \\
\text { diurética } \\
\text { Húmida, diurética } \\
\text { Húmida, diurética }\end{array}$ & \\
\hline Aves $(\$ 47)$ & $\begin{array}{l}\text { Quase todas } \\
\text { Pomba torcaz } \\
\text { Perdiz } \\
\text { Pomba } \\
\text { Galinha } \\
\text { Rola } \\
\text { Ganso }\end{array}$ & $\begin{array}{l}\text { + secas } \\
\text { a + seca, seguida } \\
\text { das restantes } \\
\text { a + húmida }\end{array}$ & $\begin{array}{l}\text { Constituição } \\
\text { dos animais } \\
\text { condicionada } \\
\text { por: } \\
\text { 1.Alimentação= } \\
\text { seca (os que } \\
\text { comem grão) } \\
\text { 2.Habitat= } \\
\text { húmida (aves } \\
\text { aquáticas) }\end{array}$ \\
\hline Ovos $(\$ 50)$ & & $\begin{array}{l}\text { Fortes, nutritivos } \\
\text { e flatulentos }\end{array}$ & \\
\hline Leite $(\S 46)$ & $\begin{array}{l}\text { Leite de vaca } \\
\text { Leite de ovelha }\end{array}$ & $\begin{array}{l}+ \text { pesado } \\
+ \text { leve }\end{array}$ & \\
\hline $\begin{array}{l}\text { Queijo } \\
(\$ 51)\end{array}$ & & $\begin{array}{l}\begin{array}{l}\text { Forte, ardente } \\
\text { (porque gordo), }\end{array} \\
\text { nutritivo e } \\
\text { adstringente (por } \\
\text { causa do suco de } \\
\text { figo usado como } \\
\text { coalho) }\end{array}$ & \\
\hline
\end{tabular}

Conforme podemos concluir da análise deste quadro, o tipo de informação que um dietista deve conhecer sobre os alimentos, por forma a deles fazer uma boa prescrição, é bastante variado. Numa altura em que 
não havia fronteiras rígidas entre diversas esferas do conhecimento, i. e., quando a especialização científica não atingira níveis de excludência como os actuais, era natural que o médico conhecesse o alimento não só do ponto de vista nutricional e terapêutico, mas também agrícola e culinário.

Saber que, no caso concreto dos animais, a sua diaita (alimentação, exercício, habitat e natureza) determina as propriedades (dynameis) que possuem as suas carnes constitui uma competência que o médico tem de articular com a identificação dos sintomas da doença e, para que o tratamento a aplicar seja mais eficiente, com o respeito pela idiossincrasia de cada paciente.

No termo deste elenco descriminado de alimentos, regista-se um cuidado metodológico muito interessante, que consiste em resumir os efeitos que em geral produzem as várias técnicas de preparação nas propriedades naturais dos produtos. Veja-se o $§ 56.2$, em que se esclarece que:

- cozer e deixar arrefecer várias vezes os alimentos é um método para retirar aos alimentos a propriedade de serem 'fortes' (ischura), ou, como se diria hoje, os seus nutrientes perdem-se com a cozedura, passando para o caldo;

- assar e grelhar são processos de confecção que reduzem a humidade dos alimentos;

- demolhar e embeber em água é o tratamento indicado para equilibrar, através da propriedade de humedecer, os alimentos secos;

- demolhar e cozer, sendo a junção de dois processos de modificação dos alimentos, vem indicado como tratamento para os alimentos salgados;

- misturar produtos com propriedades contrárias (o acre com o doce; o adstringente com o gorduroso) permite equilibrar os opostos e, do ponto de vista médico, explica a promoção da cozinha agridoce, tão ao gosto das culturas grega e romana.

Ainda no Da dieta ( $§ 70-84)$ deparamos com uma sistematização de quinze casos clínicos (nove provocados pelo excesso de comida, seis pelo predomínio dos exercícios físicos sobre a alimentação) e respectivas diaitai de cura, de que considerarei, a título ilustrativo, apenas um caso.

$\mathrm{Na}$ verdade, em comum todos eles apresentam a mesma estrutura lógica, que é a seguinte: primeiro descrevem-se os sintomas; depois a terapia a 
aplicar. Outro aspecto em comum é a ordem pela qual os produtos da dieta alimentar vêm referidos, a qual respeita a lógica da sua comparência à mesa grega, ou seja: primeiro contempla-se o pão ou outro preparado de cereias (a base da alimentação); seguem-se os vários acompanhamentos ou 'condutos' (à letra 'tudo o que é conduzido à boca pelo pão', pois não se usavam talheres) e, por fim, o vinho e/ou as sobremesas.

Atentemos no $\S 79$, em que se relata o primeiro caso de falta de assimilação de comida. Os sintomas são a evacuação sem absorção, o que origina doenças na koilia ('cavidade' em que situavam tanto os intestinos como o estômago). Em termos terapêuticos, à testa das prescrições médicas surgem os cuidados alimentares, seguidos de exercícios físicos. O tratamento é progressivo. Començando-se por reduzir a alimentação a $1 / 3$ do habitual, vai-se aumentando gradualmente as quantidades até se voltar aos valores iniciais. Tudo isto após o cumprimento de um calendário bem definido ${ }^{14}$.

As indicações sobre a alimentação têm, para os estudiosos da História da Alimentação, o particular interesse de pormenorizarem técnicas de confecção (fundamentais para o médico, pelos efeitos que têm no restabelecimento do equilíbrio dos elementos no organismo do paciente).

Assim, recomenda-se: pão de farinha com farelo, amassado sem levedura e cozido em forno do campo ou na cinza (isto é, sem adição de gordura, como sucedia quando era levado ao lume numa caçarola), servido quente, sob a forma de migas ensopadas em vinho adstingente ${ }^{15}$; dos peixes comer apenas as partes magras (lombo e rabo), preparadas de uma de duas maneiras: cozidas em água com sal ou grelhadas juntamente com vinagre;

${ }^{14}$ Sete dias da redução inicial a $1 / 3$, findos os quais se aumenta a dose de alimentos na proporção de metade dos dois terços suprimidos, seguidos de uma limpeza forçada do organismo (através do vómito). Durante mais quatro dias aumentam-se as quantidades de alimentos ingeridos, sendo que ao final de uma semana, depois do vómito, se recuperaram os níveis de consumo iniciais. Neste momento força-se o organismo a nova purificação (pelo vómito) e repete-se, desde o início, o ciclo completo de duas semanas de tratamento.

15 Esta receita afigura-se-nos uma espécie de antepassado mediterrâneo das "sopas de cavalo cansado" portuguesas tradicionalmente feitas com vinho, açúcar/mel e pão/broa aos pedaços.. 
das carnes, não a fresca, mas só a de conserva (salgada ou de vinagre ${ }^{16}$ ), e também o cão grelhado (deduz-se que é a única carne fresca que se pode comer ${ }^{17}$ ); das aves, pombas e outras similares, também cozidas ou grelhadas; dos legumes, o menos possível; vinho tinto, adstringente e preferencialmente bebido estreme.

Em suma, estamos perante uma dieta de "secagem" do ventre. Os exercícios variados (caminhadas, corridas de fundo e lutas) destinam-se também a aquecer o corpo, levando ao consumo (i.e. secagem) das humidades instaladas na região do ventre.

2. Catálogo de alimentos do Dos padecimentos (§ 39-61)

O espírito que presidiu à elaboração destas recomendações comunga com o tratado Da dieta a matriz atrás identificada, ou seja, a identificação de uma sintomatologia seguida de prescrições alimentares pormenorizadas. O autor alterna o seu discurso entre informações de carácter mais geral e outras de natureza particular. De facto, além de descrever como se compõem as dietas alimentares genéricas, o tratadista apresenta as propriedades naturais ou artificiais (i.e., objecto de preparação culinária) dos alimentos, tomados individualmente ou por categoria, e seus efeitos (\$54-58).

Relativamente às dietas generalistas, i. e. identificadas para padecimentos mais comuns, podemos caracterizá-las em seis tipos:

- dieta na doença (\$40);

- dieta pós-purga medicamentosa (\$41);

- dieta contra a obstipação e seu contrário (\$43);

- dieta na convalescença (§43);

16 Cf. $\$ 56.1$, em que se esclarece as propriedades dos dois tipos de conservação da carne: em vinagre, método que, não aquecendo tanto o organismo como a carne conservada em vinho, tem a vantagem de ser bastante nutritiva; em sal, apesar de menos nutritiva, contribui para emagrecer e secar (efeito que se deseja, pois o quadro clínico é de acumulação de humidade no ventre).

${ }^{17}$ Repare-se que, conforme vimos no quadro supra sobre carnes e derivados, o cachorro é das carnes mais secas (leia-se 'magras'), pelo que contribuirá para o efeito desejado com a dieta alimentar prescrita, a saber: aquecer o organismo (tanto mais que se recomenda que seja grelhado). 
- dieta de emagrecimento e dieta para ganhar peso (§43);

- dieta de fortalecimento e dieta ligeira (\$52).

A título exemplificativo, considere-se o conteúdo dos dois últimos tipos, de forma a detectarmos matrizes clássicas da dietética.

No que se refere à dieta de emagrecimento, recomenda-se frugalidade na comida e, paralelamente, uma forte aposta nos exercícios físicos e pouco repouso. Ao invés, o regime para aumentar de peso prescreve: não jejuar, comer sem restrições, não fazer exercício físico e dormir o que se queira.

Já na dieta pesada (rica em nutrientes), como seria de esperar, à luz da dietética actual, predominam os hidratos de carbono (o pão fresco de trigo de farinha fina), as proteínas animal mais fortes (as carnes vermelhas de bovino, leitão e porco, frescas e mal passadas) e o indispensável vinho (supõe-se que seja tinto). O seu oposto, a dieta ligeira compõe-se de pão de farinha grosseira, vinho fresco e filtrado, carnes brancas (aves e cordeiro, considerado de todas as carnes a mais 'leve'18) e caça, (destaque para a lebre), além de cão, todas bem passadas, qualquer tipo de peixe, de preferência cozido.

Repare-se que no $\$ 49$ o autor já indicara a relação entre o grau de cozedura das carnes e o seu valor terapêutico, o que não deixa dúvidas ao público (especializado ou não) das razões que levam a indicar para dietas mais leves o consumo de carnes bem cozidas/passadas, uma vez que esses processos de cocção reduzem o valor nutritivo dos alimentos, além de que ganham, por essa via, propriedades (dynameis) laxantes (mais as cozidas do que as assadas); em meia cozedura, possuem as duas propriedades em questão (são nutritivas e laxantes); já as mal cozinhadas são nutritivas, mas não laxantes.

\section{d) Saúde, Cultura e Meio Ambiente}

Quando falamos de tipos de dieta, supomos a existência de determinados universais físicos e comportamentais, aplicáveis a categorias de

18 Ainda hoje recomendado para iniciar o consumo de carne na dieta dos bebés. 
indivíduos. Assim, dos textos em análise extraímos a referência a padrões diversos, segundo os critérios considerados:

1. condição do organismo - saúde/doença: distinguem-se regimes para pessoas saudáveis e regimes para doentes. A este respeito, o autor do tratado Dos padecimentos esclarece (\$39) que o que deve ser modificado não são os alimentos - pois alterar o mínimo possível os hábitos (neste caso alimentares) do paciente é uma condição prévia para a eficiência do tratamento - mas sim as suas propriedades, recorrendo, para tal, à arte culinária, ou como se diz no texto, 'a prepará-los frios, quentes, húmidos ou secos'.

Aliás, porque o apetite de um doente, no geral, diminui, a alimentação dos doentes não deve pô-lo mais em risco. Pontualmente, chama-se a atenção para esmerar a preparação das carnes e peixes cozidos, a servir durante a convalescença ( $\$ 43)$. De um modo mais directo aborda-se a mesma questão no $\$ 44$ desse mesmo texto:

De quanto pão, condutos e bebidas os doentes desejarem, ponham-nos à sua disposição, se daí não vier nenhum mal ao corpo. Quando se começar a acrescentar ou a retirar comidas ou bebidas, é preciso fazer o acrescento e a redução aos poucos. A quantos são capazes de comer uma quantidade suficiente de alimentos, não é preciso dar-lhes papas, pois elas criam repulsa à comida; porém, a quantos não o forem, dá-lhas. Mas se quiseres dar-lhes alguma coisa para se restabelecerem, é dares-lhes uma tisana de espelta ou trigo, uma vez que são mais fortificantes que as papas; serve-a depois do jantar.

Neste trecho, além da observância do princípio de não comprometer o apetite do doente, importa retirar duas outras práticas de ancestralíssimas origens, mas ainda hoje vivas, na alimentação dos doentes: o recurso a uma dieta pastosa, mais fácil de deglutir, embora com o efeito indesejado de poder contribuir para a redução do apetite; a ingestão de suplementos nutricionais, adicionados à dieta comum. 
2. Género e idade dos indivíduo: composições distintas dos organismos, de acordo com a idade e o sexo, fazem supor dietas também diversas entre si. Uma vez que a alimentação e os exercícios físicos devem prover o equilíbrio, o médico tem de saber qual a natureza dos corpos que trata, ainda que esta seja condicionada por outros elementos externos (geografia, clima, costumes), para lhes prescrever o consumo de alimentos com propriedades opostas.

Essa tipologia genérica da natureza dos corpos encontramo-la nos $\S$ 33-34 do Da dieta e resume-se à seguinte caracterização: criança (mistura de elementos quentes e húmidos); jovem (mistura de elementos quentes e secos); homem adulto (seco e frio); género feminino (húmido e frio) vs. género masculino (seco e quente); velhos (frios e húmidos).

3. Estação do ano: os regimes de Inverno, Primavera, Verão e Outono (Da dieta 68) constituem os quatro padrões de diaita mais genéricos, pelo que o autor os apresenta como viáveis para o homem comum (i. e., a maioria trabalhadora da população).

Assente na concepção base de que os opostos se completam, as propriedades dos alimentos, os exercícios prescritos (incluindo o coito) e as recomendações em matéria de repouso (sono e banhos) destinam-se a promover efeitos contrários aos dos climas extremados do Inverno e do Verão (frio e quente/húmido e seco) e aos climas amenos da Primavera e do Outono. O mesmo princípio da adaptação progressiva dos sujeitos a mudanças, que já referimos antes a propósito da dieta alimentar, encontramo-lo, agora, a sustentar toda a filosofia dos regimes sazonais.

O tratadista não só defende que na passagem do Inverno para o Verão os indivíduos tenham um regime de adaptação de cinco dias (§68.7), como, ao descrever a diaita primaverial, a subdivide em seis períodos iguais, de oito dias cada, sendo que, no conjunto, se assiste a uma evolução progressiva e adaptação lenta às particularidades climatéricas da nova estação (§68.10).

Porque a teoria que determina a diaita (seja ela sazonal, de género ou patológica) é a dos opostos, compreende-se que os perfis desenhados pelo escritor hipocrático e por nós resumidos sejam os seguintes: 
a) Dieta de Inverno:

- propriedades dos alimentos a consumir: secura, adstringência e calor;

- categorias de alimentos, bebidas e pratos recomendados: pão (em maior quantidade), condutos grelhados e vinho tinto (menos diluído e em menor quantidade) - e esta é a tríade básica da refeição grega; repare-se na ênfase colocada nos hidratos de carbono, necessários à reposição de calorias, na preparação de alimentos em contacto directo com o fogo (o que permite secá-los e conferir-lhes calor, propriedades opostas às do clima da estação invernosa) e na apologia do consumo de vinho tinto (quente e seco), mas pouco diluído em água (pois esta é fria e húmida, cf. $\$ 52.1)$;

- pratos desaconselhados: legumes (à excepção dos quentes e secos), cozidos e sopas; os primeiros não abundariam na estação em apreço, ao passo que a presença da água, no caso das duas formas de preparação desaconselhadas, contribuiria para aumentar a humidade, quando o que se pretende é combatê-la;

- esforço físico recomendado:

- exercícios de toda a espécie (corridas, luta, caminhada);

- o coito (para os velhos e não para os novos, pois já vimos que os primeiros são frios e os segundos quentes);

- o vómito provocado (mais frequente no caso das pessoas gordas/húmidas - i.e, três vezes por mês- e menos para os magros/secos - i.e., duas vezes por mês; após a ingestão excessiva de alimentos mais pesados, como são as carnes de bovino e porco, o quejo, os doces, as gorduras não usuais ${ }^{19}$, e o vinho; também em situação de alteração brusca de hábitos alimentares ou de residência ${ }^{20}$ );

- vida ao ar livre: expor o corpo aos rigores do clima contribui para o seu fortalecimento, verdade que o paralelismo entre o ser humano e as árvores confirma, como se lê em \$68.6:

\footnotetext{
19 Embora nada se diga, é óbvio que a gordura habitual era o azeite.

${ }^{20}$ A exposição da casa aos ventos tem implicações na saúde, logo na dieta, dos indivíduos, conforme largamente atesta o tratado Das águas, dos ares e dos ventos.
} 
[Convém] também enfrentar, sem medo, o frio, excepto a seguir à refeição ou aos exercícios de ginástica, mas logo nas caminhadas matinais, quando o corpo começa a aquecer, nas corridas em qualquer outra circunstância, desde que se guarde de excessos! Não é bom, de facto, para o corpo não se expor aos rigores do Inverno! Nem as árvores, se não se tiverem exposto aos rigores do Inverno, são capazes de frutificar e de se fortalecerem. [Convém] praticar todo o tipo de esforços nessa estação, sem excesso, claro, e desde que não provoquem dores!

Os exercícios mais adequados para os espaços abertos, fora do recinto porticado das palestras, eram a marcha ou a corrida, pois exigem circuitos amplos. Por questões de equilíbrio (o mesmo é dizer de saúde) o indivíduo tem de evitar a prevalência de determinada dymanis sobre as outras. Ou seja, se a comida ingerida e os exercícios permitem adquirir calor (contrariando o frio da época), expor-se ao frio depois da refeição ou da ginástica teria por resultado voltar ao arrefecimento indesejado do organismo. Em suma, para ser profilático, o treino físico ao ar livre no inverno deve dar-se quando o organismo precisa de ganhar temperatura (exercitando-se) e não de perdê-la.

b) Dieta de Primavera: destaco, brevemente, no domínio alimentar, a referência à ingestão de alimentos e bebidas emolientes e leves (no caso das bebidas, aconselha-se a terem mais água e a serem mais brancas - repare-se que em $\$ 52.2$ se disse que o vinho branco refrescava e humedecia, propriedades favoráveis à aproximação da estação do calor).

Sendo um período de transição para a estação do calor, a dieta passa por um processo de adaptação, caracterizado pela substituição gradual de regimes alimentares (pelo que nessa fase coexistem, por exemplo, os pratos assados, típicos da estação anterior, com os cozidos) e pela redução de todo o tipo de esforços (que levavam à produção de calor: exercício físico, coito e vómito provocado).

c) Dieta de Verão: comer no geral menos e ingerir líquidos em quantidade suficiente, à refeição; agora os legumes e os cozidos são re- 
comendáveis, bem como a fruta da época, à refeição; reduzir o coito; os banhos aconselháveis são os tépidos; os exercícios físicos recomendados são mais moderados.

Repare-se que, na esfera do repouso, se aconselha uma pequena sesta depois do almoço, prática considerada salutar, muito provavelmente pelas mesmas razões que ainda hoje a justificam em diversos países envolventes da bacia do Mediterrâneo (os Verões muito quentes e de dias longos).

Veja-se, ainda, a tradução de $\$ 68.13$, reveladora de que a dieta prescrita visa expurgar o indivíduo da alimentação que promove o calor, substituindo-a por outra mais fresca, adequada ao Verão que se aproxima:

Continuar com esta dieta até ao solestício, de modo a, no decurso deste período de tempo, cortar com tudo o que é seco, quente, negro e sem mistura ${ }^{21}$, e com o pão, salvo se for só um bocadinho (para satisfazer o desejo). Durante o período que se segue, praticar-se-á uma dieta com [alimentos] emolientes, húmidos, refrescantes, brancos e puros, até ao aparecimento de Arcturo ${ }^{22}$ e do equinócio, durante noventa e três dias.

Este trecho oferece ainda uma nota curiosa sobre a flexibilidade com que deve ser encarado qualquer regime. Na verdade este não pode assumir-se como uma lei de aplicação inflexível, uma vez que se admite que, em nome do prazer do gosto, se permitam ligeiras infracções (como é comer pão, um alimento que aquece, numa estação em que se deve privilegiar o consumo de preparados com propriedades refrescantes).

Dito de outra maneira, na medicina antiga havia já consciência de que um alimento não é só um nutriente e um produto terapêutico, mas também um prazer gastronómico!

${ }^{21}$ Provável alusão ao vinho tinto, que, no Inverno, para fornecer mais calor ao organismo humano, deve ser consumido praticamente 'sem mistura' (no texto grego usa-se o adjectivo com esse sentido: akratos). O vinho branco, ao invés, aconselhavam os dietistas que se bebesse no Verão, devido às suas propriedades refrescantes.

22 Constelação situada diante da Ursa (daí o seu nome formar-se a partir do substantivo que significa 'urso/a', arktos) e que é visível em meados de Setembro, precisamente no termo do Verão. 
d) Dieta de Outono: concebida, tal como sucedeu com a dieta primaveril, como um regime de transição entre as duas estações mais extremadas do ponto de vista climatérico (o Verão e o Inverno). Veja-se \$68.14:

A partir do equinócio, este é o regime que se deve praticar, gradualmente, desde final do Outono até chegar ao Inverno, guardando-se das mudanças de frio e de calor com uma roupa grossa: nesse período de tempo, depois de realizar os exercícios de aquecimento com uma túnica vestida, fazer as massagens e lutar untado de azeite; fazer caminhadas ao sol; tomar banhos quentes; deixar de parte as sestas; [servir-se de] comidas mais quentes, menos húmidas e puras e de bebidas mais escuras, emolientes e sem água misturada, e de legumes secos (um pouco menos); avançar para um regime completamente diferente, suprimindo [os hábitos] do Verão; servir-se [dos recursos] do Inverno, mas não em pleno, de forma a chegar o mais perto possível do regime de Inverno em quarenta e oito dias, desde o equinócio até ao ocaso das Plêiades.

Neste trecho encontramos a única referência ao vestuário, quando se aconselha a prática de exercícios físicos vestido. Outras alterações interessantes são mudar a hora das caminhadas, por forma a estas serem feitas ao sol (que começa a perder intensidade, logo não prejudica os treinos), a supressão da sesta e a introdução dos banhos quentes, além de que, em termos alimentares, assiste-se ao movimento inverso ao realizado na Primavera, ou seja, a uma eliminação progressiva do que se comia no Verão e à aproximação à dieta de Inverno (consumo de alimentos quentes e menos húmidos).

4. Região de origem dos produtos: segundo uma lógica de relação de osmose entre os produtos e a sua região de origem ( $\$ 56.4$ ), postula-se que os alimentos possuem as propriedades equivalentes às dos seus territórios de produção. Daí pudermos inferir que as populações das regiões mais áridas, quentes e secas possuam, em teoria, uma base alimentar mais rica em nutrientes (ou como escreve o tratadista 'proporciona mais força ao corpo'), do que as das regiões produtores de alimentos emolientes, leves e frios (naturais em locais húmidos, chuvosos e frios). 


\section{OBSERVAÇÕES FINAIS}

Em suma, os condicionalismos naturais e culturais têm de ser ponderados, quando se pretende eleger uma dieta alimentar saudável, pois um mesmo alimento ora é benéfico ora prejudicial, de acordo com a pessoa (seu metabolismo) e condicionalismos externos ${ }^{23}$.

Todas estas recomendações médicas são, no entanto, normas de validade relativa, pois, numa exemplar mostra de humildade científica, o autor do Da dieta (\$67.1-3), admite ser impossível ter certezas absolutas, pois a consciência da biodiversidade (do ser humano, antes de tudo o mais, bem como dos alimentos) e até a eficácia dos medicamentos são imponderáveis que ninguém consegue com absoluto rigor avaliar:

1. Sobre o regime dos seres humanos - tal como já disse anteriormente - não é possível escrever com absoluto rigor, de modo a determinar a proporção justa de exercícios face à quantidade de alimentos! Muitos são os factores que o impedem.

Em primeiro lugar a constituição dos indivíduos é diversa: as [constituições] que são secas são mais ou menos secas, quer em si mesmas quer por comparação umas com as outras; passa-se o mesmo com as húmidas e com todas as outras.

2. Além disso as idades não têm todas as mesmas necessidades; e há ainda a localização geográfica das terras, as mudanças dos ventos, a passagem das estações e as condições climatéricas do ano.

Entre os próprios alimentos há ainda uma grande diversidade: trigos diferentes de outros trigos, vinho de outro vinho e de igual modo tudo o resto de que compomos a nossa dieta. Todas estas diferenças impedem que se escrevam certezas absolutas.

3. Não obstante são descobertas minhas os diagnósticos sobre os elementos que predominam no organismo, se são os exercícios que predominam sobre os alimentos, se os alimentos sobre os exercícios, e como

23 Vejam-se também os exemplos dados a propósito do leite, carne e vinho, no Do alimento 32, e do queijo, no Da Medicina Antiga 20. 
se deve tratar cada uma das situações, prevenir a saúde, de modo a que as doenças não sobrevenham, sem se cometerem erros particularmente graves e frequentes; nestes casos já há necessidade de medicamentos, mas situações há em que não se pode recuperar a saúde nem com medicamentos.

O que era possível descobrir-se, próximo desse limite cheguei com as minhas descobertas, mas a certeza absoluta ninguém a descobriu. 


\title{
OS NÚMEROS E A NATUREZA DO MUNDO NO PitAgorismo ANTigo
}

\author{
Numbers and the nature of the world \\ in ancient pythagoreanism
}

Gabriele Cornelli

Universidade de Brasília

\begin{abstract}
RESUMO
A pergunta "Tudo é número?", que intitula significativamente o célebre artigo de Zhmud na revista Phronesis de 1989 ("All is number?"), inaugura uma contestação do testemunho aristotélico central para a historiografia do pitagorismo, segundo a qual "tudo é número" seria a definição fundamental da filosofia pitagórica. Tarefa esta não certamente fácil, especialmente quando se considera que tanto a história da filosofia antiga quanto aquela da matemática antiga não pareceram ter muitas dúvidas, até então, em relação a essa mesma atribuição. O presente ensaio deseja submeter a revisão crítica a afirmação aristotélica pela qual os pitagóricos acreditariam tudo ser número". Nossa análise das várias passagens e maneiras pelas quais Aristóteles afirma isso revelará, para além de meras variantes semânticas, uma contradição teor ética fundamental que o próprio Aristóteles parece incapaz de resolver. Três diferentes versões da doutrina estão, de fato, presentes na doxografia aristotélica: a) uma identificação dos números com os objetos sensíveis; b) uma identificação dos princípios dos números com os princípios das coisas que são; c) uma imitação dos números pelos objetos reais. Enquanto as versões a) e c) revelaram clara intenção polêmica de Aristóteles contra a militância platônica pela causa formal, a versão b), dos números como causas formais da realidade, demonstra ser uma reconstrução aristotélica da tese pitagórica. A esta reconstrução Aristóteles teria sido levado de um lado pela dificuldade de aceitar a noção pitagórica material de número, por outro lado, por considerá-la mais próxima à sua sensibilidade, fortemente marcada pela recepção dessa mesma teoria em âmbito acadêmico.
\end{abstract}

PAlAVRAS-ChAVE: Filosofia Antiga, Pitagorismo, Aristóteles, Números. 
ABSTRACT

The question, "All is number?", significantly the title of Zhmud's 1989 article in Phronesis, opens a challenge to the extremely important Aristotelian testimony that "all is number" was the fundamental definition of Pythagorean philosophy. Such a challenge is anything but easy, especially when one considers that, so far, the histories of both ancient philosophy and ancient mathematics seemed to have no doubts that this definition was correct. This paper aims to submit Aristotle's claim that the Pythagoreans believed that "all is number" to critical review. Our analysis of the many ways that Aristotle states the thesis "all is number" will reveal, beyond merely semantic variations, a fundamental theoretical contradiction that Aristotle himself seems incapable of solving. Three different versions of the doctrine are in fact present in the Aristotelian doxography: a) an identification of numbers with the sensible objects; b) an identification of the principles of numbers with the principles of things that are; c) an imitation of objects by numbers. While versions a) and c) seem to identify numbers with the material cause of reality, in terms ("imitation") reminiscent of Plato, version b), numbers as formal causes of reality, is an Aristotelian reconstruction of the Pythagorean theory. Aristotle would have been pushed to such a reconstruction by the difficulty he found in accepting the Pythagorean material notion of number, and by considering it closer to its sensitivity, strongly marked by the reception of that same theory in the Academic realm.

KEY-WORDS: Ancient Philosopophy, Pythagoreanism, Aristotle, Numbers..

\section{O RESUMO DA Filosofia Pitagórica POr PORFírio: UMA AUSÊNCIA SIGNIFICATIVA}

Porfírio resume em poucas linhas aquelas que a tradição passará a considerar como as doutrinas centrais do Pitágoras bistórico. ${ }^{1}$ Seu resumo é mais significativo por aquilo que deixa de mencionar do que pelo que ele cita:

Algumas das afirmações [de Pitágoras] ganharam notoriedade praticamente geral: 1) afirma que a alma é imortal; 2) que transmigra em outras espécies de seres vivos; 3) que, periodicamente, o que já aconteceu uma vez volta a acontecer, e nada é absolutamente novo; e 4) que todos os

${ }^{1} \mathrm{O}$ presente ensaio constitui-se de uma revisão de uma parte do capítulo quarto de meu livro O pitagorismo como categoria historiográfica (Coimbra, 2011). A pesquisa da qual esse resultou foi apoiada pela CAPES/Ministério da Educação/Brasil (Projeto 18218121). 
seres animados devem ser considerados como do mesmo gênero. Ao que parece foi mesmo Pitágoras a introduzir pela primeira vez estas crenças na Grécia (Porph. VP: 19). ${ }^{2}$

De fato, no bojo dessas doutrinas apontadas como originárias, não aparece nenhuma referência à matemática ou à teoria astronômica, por exemplo, ou mesmo à cosmologia e à política, que têm, ao contrário, papel fundamental para a definição do pitagorismo em outros estratos da tradição. A ausência é ainda mais significativa quando se pensar que a tradição remonta provavelmente já ao pupilo de Aristóteles Dicearco. ${ }^{3}$ Ela sugere a necessidade de uma consideração mais atenta da história da atribuição ao pitagorismo antigo de uma teoria matemática ou de alguma relação com o estudo dos números. ${ }^{4}$

Longe da confiança que Zeller depositava na possibilidade de resumir as doutrinas do pitagorismo na teoria pela qual o número seria a essência de todas as coisas (junto com as doutrinas da harmonia, do fogo central e das esferas), todas elas significativamente presentes nos fragmentos de Filolau, a crítica contemporânea submeteu a uma profunda revisão o pretenso dogma aristotélico pelo qual, no pitagorismo, "tudo é número”. A tradição interpretativa, certamente encabeçada em tempos mais

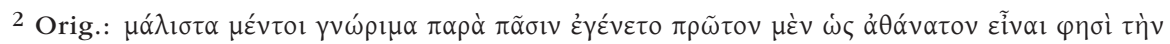

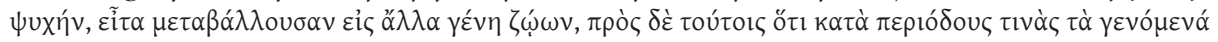

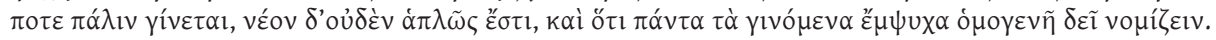

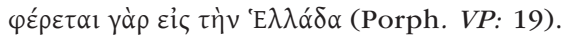

3 Burkert (1972: 122-123), apesar da resistência por parte tanto de Rathmann (1933: 3ss.) como de Wehrli, que não acolhe o capítulo 19 de em seu volume dedicado a Dicearco (Wehrli 1944), segue a tradição desta atribuição que conta com a anuência de Rohde (1871: 566), Burnet (1908: 92), Lévy (1926: 50), Zeller e Mondolfo (1938: 314). E acrescenta argumentos francamente convincentes, fundamentados no tom cético que a passagem deixa transparecer e que não pode certamente sem atribuído ao crente Porfírio: deverá sem mais plausivelmente criação de Dicearco, cético pupilo de Aristóteles, que em outros fragmentos revela o mesmo ceticismo e ironia: este afirma, por exemplo, que alma seria uma simples palavra (fr. 7 Wehrli) e que Pitágoras teria sido, no passado, uma bela cortesã (fr. 36 Wehrli). A passagem foi incluída como fr. 40 na mais recente edição de Dicearco por Mirhady (Fortenbaugh \& Schütrumpf 2001).

${ }^{4}$ Não é acaso, de fato, que diversos comentadores já clássicos se deram conta da importância dessa passagem para reposicionar teoreticamente as origens da filosofia pitagórica em estreita conexão com as temáticas ético-religiosas. Cf. para isso De Vogel (1964: 16) e Guthrie (1962: 186).
} 
recentes por Frank (1923), acostumou-se a considerar toda a matemática pitagórica como uma invenção acadêmica, posterior, portanto, aos mesmos fragmentos de Filolau, que devem, eles mesmos, ser considerados espúrios. A influência do ceticismo de Frank é tamanha ao ponto de alguém como Cherniss (1935), que diverge dele na concepção fundamental do valor a ser atribuído ao testemunho de Aristóteles, concordar, ao invés, neste ponto com o primeiro.

O consenso dos comentadores é especialmente impressionante quando diz respeito àquele que consideramos como um dos loci fundamentais desse debate, isto é, o valor a ser conferido aos fragmentos de Filolau:

Os fragmentos atribuídos a Filolau são certamente espúrios, por eles conterem elementos que não podem ser mais antigos que Platão. Erich Frank reuniu as evidências contra os fragmentos; e, apesar de sua própria teoria sobre suas origens e a conclusão de argumentos certamente muito fracos $[\ldots]$, sua análise torna supérfluo ter de recomeçar o devastante caso contra eles (Cherniss 1935: 386). ${ }^{5}$

Mais recentemente, a posição de Frank, e da grande maioria dos comentadores, recebeu profunda revisão crítica, por parte de autores como Burkert (1972: 238-277) e Kirk, Raven e Schofield (1983: 324).

Especialmente significativos, nesse sentido, são os esforços de Huffman, tanto em seu artigo de 1988 quanto, especialmente, em sua monografia inteiramente dedicada a Filolau e aos problemas da autenticidade de seus fragmentos (1993): a primeira inteiramente dedicada ao filósofo de Crotona depois da monografia de Boeckh de $1819 .{ }^{6}$ Essa revisão abre

5 Orig.: The fragments attributed to Philolaus are surely spurious, since they contain elements that cannot be older than Plato. Erich Frank has gathered the evidence against the fragments; and, apart from his own theory as to their origin and his conclusion of certain very weak arguments [...] his analysis makes it superfluous to restate the overwhelming case against them.

${ }^{6}$ Para uma geral concordância dos comentadores com o ceticismo de Frank, cf., entre outros, Burnet (1908: 279-284) e Lévy (1926: 70ss.). Não é certamente o caso de concordar, portanto, com Spinelli (2003; 145 n345), quando "despacha" a questão da autenticidade dos fragmentos desta forma: "apesar do muito que já se escreveu a favor e contra eles, toda a 
novas perspectivas hermenêuticas e, junto com os recentes estudos de (1989; 1997 e agora 2012 e 2013), representa uma pedra angular para a definição do lugar da matemática na construção da tradição pitagórica. ${ }^{7}$

\section{Três VERSões da doUtrina PITAgórica dos números}

A pergunta “Tudo é número?”, que intitula significativamente o célebre artigo de Zhmud na revista Phronesis de 1989 ("All is number?"), inaugura uma contestação do testemunho aristotélico central para a historiografia do pitagorismo, segundo a qual "tudo é número" seria a definição fundamental da filosofia pitagórica. ${ }^{8}$ Tarefa esta não certamente fácil, especialmente quando se considera que tanto a história da filosofia antiga quanto aquela da matemática antiga não pareceram ter muitas dúvidas, até então, em relação a essa mesma atribuição.9

E os motivos para tal confiança aparentemente não faltam. Com efeito, em Aristóteles, a atribuição da doutrina do "tudo é número" aos pitagóricos recorre diversas vezes e acaba por resumir aquela que é a interpretação aristotélica do pitagorismo.

Aristóteles afirma repetidamente que:

"Pensavam serem os elementos dos números os elementos de todas as coisas

argumentação se encontra exposta, de um modo adequado, somente nos trabalhos de três tratadistas": Bywater, Frank e Mondolfo.

${ }^{7}$ A bem da verdade, é o caso de ressaltar que o próprio Frank teria em seguida amenizado, em seus escritos sucessivos, uma posição que, por seu ceticismo extremo e, de certa forma, paralisador, não resistiu às críticas dos outros comentadores. De fato, em 1955, deverá admitir que it can hardly be doubted that Pythagoras was the originator of this entire scientific development: he was a rational thinker rather than an inspired mystic (1955: 82). Não obstante, em sua resenha do livro de Von Fritz sobre a política pitagórica, sua verve cética ainda aparece fortemente presente (Frank 1943).

8 Ainda que algumas sugestões nesse sentido já haviam sido formuladas por Huffman (1988), em seu artigo sobre o papel do número na filosofia de Filolau, as observações não foram declaradamente recebidas no artigo de Zhmud (1989: $292 \mathrm{n} 62$ ), pois este foi desenvolvido paralelamente ao artigo do primeiro.

${ }^{9}$ Cf. para as citações, Heath (1921: 67), Guthrie (1962: 229ss.), Huffman (1988: 5 e 1993: 57). 
e que a totalidade do céu é harmonia e número" (Met. 986a3).10

"Os números, conforme dissemos, correspondem à totalidade do céu" (Met. 986a21). ${ }^{11}$

"Eles dizem que os números são as próprias coisas" (Met. 987b28). ${ }^{12}$

"Aqueles [filósofos] dizem que as coisas são número" (Met. 1083b17). ${ }^{13}$

"Fizeram os números serem as coisas que são" (Met. 1090b23). ${ }^{14}$

Aristóteles, assim, por seis vezes, faz os pitagóricos afirmarem que a realidade como um todo (tá ónta, tón ólon oûranon, tá prágmata) "é número".

Em contrapartida, por outras sete vezes, Aristóteles parece sugerir que os pitagóricos digam algo levemente distinto:

"Não há outro número além do número pelo qual está constituído o mundo" (Met. 990a21).15

"Também para os pitagóricos só existe o número matemático: mas eles afirmam que este não é separado e que, antes, é dele que se sustentam as coisas sensíveis, pois eles constroem o céu inteiro com números" (Met. 1080b16-19). ${ }^{16}$

"É impossível afirmar que [...] os corpos são feitos de números" (Met. 1083b11). ${ }^{17}$

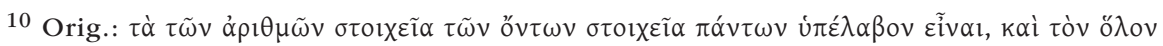

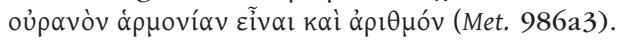

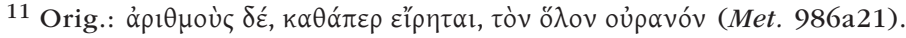

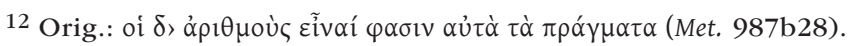

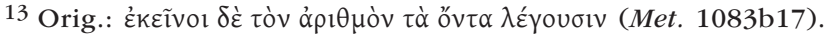

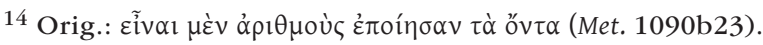

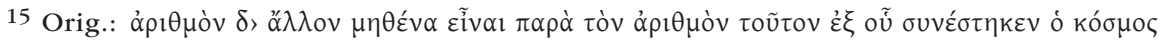
(Met. 990b21).

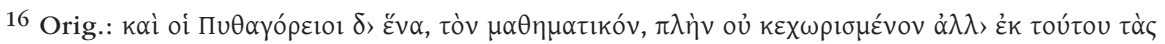

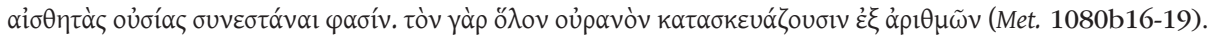

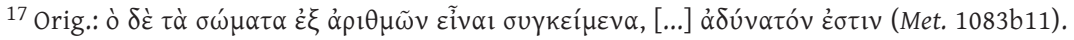


"Fizeram os números serem as coisas que são, mas não de maneira separada, e sim de números são constituídas as coisas que são" (Met. 1090a23-24). 18

"Fazem derivar os corpos físicos dos números" (Met. 1090a32). 19

"Chegam ao mesmo resultado também aqueles que consideram que o céu é feito de números" (De caelo 300a16).20

Nas citações acima, o que Aristóteles faz os pitagóricos afirmarem, mais precisamente, é que a constituição do mundo se daria ex arithmôn, isto é, com os números como sua matéria constitutiva (e, portanto, imanente).

Essa variabilidade da lectio aristotélica marca toda sua abordagem ao pitagorismo (Burkert 1972: 45). Não diferentemente, aqui a apresentação da doutrina do "tudo é número" por Aristóteles é, no limite, contraditória e apresenta basicamente três diferentes significados. ${ }^{21}$ Para além da primeira versão, que se refere à identificação fundamental dos números com os objetos sensíveis, duas outras versões são fornecidas por Aristóteles.

A segunda delas é a da identificação dos princípios dos números com os princípios das coisas que são:

Os assim chamados pitagóricos são contemporâneos e até mesmo anteriores a estes filósofos [Leucipo e Demócrito]. Eles por primeiros aplicaram-se às matemáticas, fazendo-as progredir e, nutridos por elas, acreditaram que os princípios delas eram os princípios de todos os seres (Met. 985b23-26). ${ }^{22}$

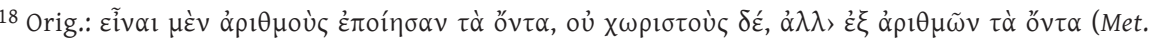
1090a23-24).

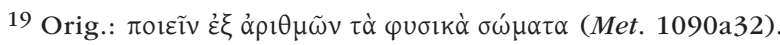

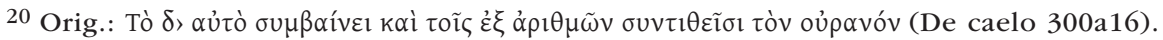
Observa com razão Huffman (1988: 5 n15; 1993: 57 n2) que Aristóteles inclui, nestes, também os atomistas.

${ }^{21}$ Reproduzem essa mesma tripartição Cherniss (1935: 386), Zhmud (1989: 284-286) e Huffman (1993: 60).

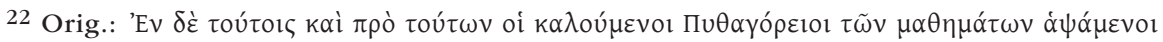

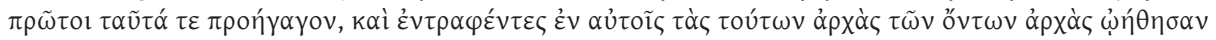

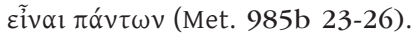


Essa versão pode ser aproximada daquela de Met. 986a3, que no lugar de archai refere-se a stoichéia.

A terceira é a da imitação dos números pelos objetos reais, na célebre passagem em que é desenhado um paralelismo com a concepção platônica da participação:

Os pitagóricos dizem que os seres subsistem por imitação dos números. Platão, ao contrário, diz por participação, mudando apenas o nome. De todo modo tanto uns como o outro descuidaram igualmente de indicar o que significa participação e imitação das ideias (Met. 987b11-14). 23

A primeira versão, pela qual "os números são as coisas", é evidentemente contraditória com as outras duas. Cherniss (1935: 387) anota, com razão, que Aristóteles procura conciliar esta primeira versão com a segunda, aqui citada, pela qual os números seriam princípios de todas das coisas.

O sucesso de sua tentativa depende de ele forçar uma teoria da derivação da realidade do número um que, todavia, além de não existir como tal nas fontes, aparentemente confunde a cosmologia pitagórica com a teoria dos números (Cherniss 1935: 39). Tentativa, esta, que o próprio Aristóteles parece reconhecer como falimentar quando afirma:

Esses filósofos também não explicam de que modo os números são causas das substâncias e do ser. São causas enquanto limites das grandezas, e do mesmo modo como Eurito estabelecia o número de cada coisa? (Por exemplo, determinado número para o homem, outro para o cavalo, reproduzindo com pedrinhas a forma dos viventes, de modo semelhante aos que remetem os números às figuras do triângulo e do quadrado [...] (Met. 1092b8-13). ${ }^{24}$

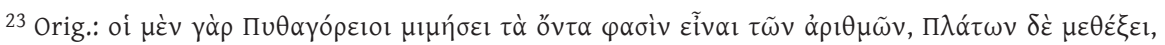

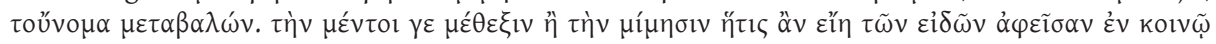

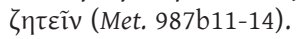

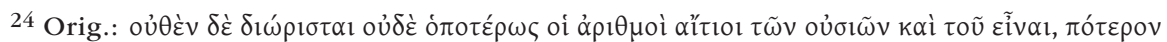

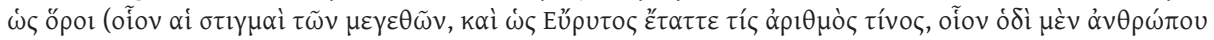


Com a referência a Eurito, Aristóteles introduz uma teoria que foi chamada de "atomismo numérico", pela qual os números seriam as coisas porque os números (pensados como pséphoi, pedrinhas) constituem a matéria pela qual as coisas são feitas. Com razão, de fato, anota Cherniss (1951: 336) que, dessa forma, os números poderão identificar qualquer tipo de objeto fenomênico:

Pensaram os números como grupos de unidades, sendo as unidades pontos materiais entre aquilo que é "sopro" ou um "vazio" material; e identificaram literalmente todos os objetos fenomênicos por meio de uma tal agregação de pontos, fossem eles divisíveis ou menos. Esta era mais uma materialização do número do que uma materialização da natureza, mas esta parecia indubitalvelmente aos pitagóricos a única maneira de explicar o mundo físico nos termos daquelas proposições genuinamente matemáticas que eles haviam provado serem independemente válidas (Cherniss 1951: 336). ${ }^{25}$

Tannery (1887b: 258ss.), Cornford (1923: 7 ss.) e o próprio Cherniss (1935, 387), fascinados pela primitividade do método atomístico-numérico de Eurito, consideraram-no efetivamente antigo. Todos seguem basicamente Frank (1923: 50) e sua hipótese pela qual a teoria teria sido emprestada por Arquitas do mesmo Demócrito.

Não por acaso, a referência da citação de Met. 985b23-26 é a Leucipo e Demócrito, isto é, à tradição atomista, à qual a teoria pitagórica é aproximada. Além disso, foi vislumbrada na polêmica zenoniana contra a pluralidade exatamente uma referência ao atomismo numérico dos pitagóricos. Todavia, Burkert (1972: 285-288) e Kirk, Raven e Schofield

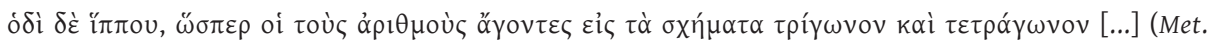
1092b8-13).

25 Orig.: Numbers they beld to be groups of units, the units being material points between which there is 'breath' or a material 'void'; and they quite literally identified all phenomenal objects with such aggregations of points, without, of course, considering whether these material points were themselves divisible or not. This was rather a materialization of number than a mathematization of nature, but it undoubtedly seemed to the Pythagoreans to be the only way of explaining the physical world in terms of those genuinely mathematical propositions which they had proved to be independently valid. 
(1983: 277-278) colocaram em sérias dúvidas essa atribuição. Os argumentos para isso não faltam. ${ }^{26}$

Entretanto, não é difícil imaginar que a materialidade dos números pitagóricos possua um sentido mais arcaico, sem a necessidade de postular necessariamente um atomismo numérico. Sentido este bem resumido pela já clássica definição de Nussbaum:

A noção de arithmos é sempre conectada de forma muito próxima com a operação do contar. Para que algo seja um arithmos deve ser de tal forma que possa ser contado - o que em geral significa que ou possui partes distintas e ordenadas ou que seja uma parte distinta de um interior maior. Fornecer o arithmos de algo que há no mundo corresponde a responder à pergunta "quantos" deste. E quando o grego responde "dois" ou "três", ele não considera que esteja introduzindo uma nova entidade, e sim que esteja separando ou medindo as entidades que já estão em questão (Nussbaum 1979: 90). ${ }^{27}$

O número seria, ainda, "ele próprio uma coisa" (Burkert 1972: 265). 28 No mesmo contexto, Burkert anota com razão que não deve ser esquecido que o $\alpha \rho \imath \theta \mu o ́ \varsigma$ possui certo "som aristocrático", que remete para aquilo que "conta" no sentido de ser importante, de "valer a pena" ser contado. O termo pode ser assim aproximado ao de ỏ $\rho x \eta ́$ pré-socrático.

Assim, a segunda concepção, acima citada, pela qual os princípios dos números seriam os princípios de todas as coisas, corresponderá mais facilmente àquela que Cherniss (1935: 390) define como uma "construção aristotélica da tese pitagórica”. Aristóteles teria sido levado a esta síntese,

\footnotetext{
${ }^{26}$ Ainda que não seja o caso de referir aqui todos eles. Para os argumentos contrários à tese de Frank, cf. Cherniss $(1935 ; 388-389)$. Para os argumentos contrários à tese da polêmica zenoniana, cf. Burkert (1972: 285-289).

27 Orig.: the notion of arithmos is always very closely connected with the operation of counting. To be an arithmos, something must be such as to be counted - which usually means that it must either have discrete and ordered parts or be a discrete part of a larger whole. To give the arithmos of something in the world is to answer the question 'how many'about it. And when the Greek answers 'two' or 'three' he does not think of himself as introducing an extra entity, but as dividing or measuring the entities already in question.

28 Orig.: Is itself a thing (Burkert 1972: 265).
} 
de um lado, pela dificuldade de aceitar a noção pitagórica material de número (aquela das pedrinhas de Eurito, que devia considerar demasiadamente simplória), por outro lado, por considerar mais procedente compreender a existência dos números pitagóricos da mesma maneira como os platônicos tratavam dela, isto é, considerando os arithmoí como archaí. Porém, com isso, Aristóteles faz deslizar toda a problemática da teoria dos números pitagórica para o âmbito acadêmico.

Com efeito, Frank (1923: 255) sugere que a fonte dessa "incompreensão" de Aristóteles seja Espeusipo e, portanto, aquela parte da Academia profundamente ligada às tradições pitagóricas. Espeusipo seria, de fato, citado diretamente por Aristóteles em Metafísica (1085a33), quando menciona aqueles "pelos quais o ponto não é um, mas semelhante ao um”, isto é, ô̂on to én.

O ponto, de fato, joga um papel central no trabalho de Espeusipo, que, além de estudioso de Filolau, declarava abertamente ter baseado neste último seus escritos. Essa afirmação encontra-se no fr. 4 (Lang) de Espeusipo, preservado por Nicomaco como parte do livro do primeiro Sobre os números pitagóricos.

O mesmo fragmento constitui a prova direta da derivação acadêmica da teoria dos princípios dos números. Assim, de fato afirmaria Espeusipo: "quando se considera a geração: o primeiro princípio do qual se gera a grandeza é o um, o segundo a linha, o terceiro a superfície, o quarto o sólido" (44 A13 DK // Fr. 4 Lang). 29

É também contraditória com a primeira tese a terceira, isto é, a ideia da mímesis dos números pelos objetos reais. A bem ver, essa tese é referida por Aristóteles com precisão somente uma vez (Met. 987b11), no interior da passagem em que a concepção pitagórica é identificada com aquela platônica da participação. Isso faz Cherniss (1935: 392) e Zhmud

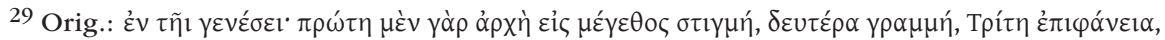

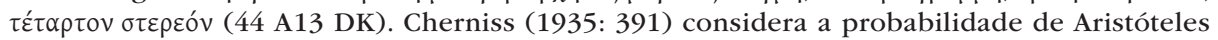
ter derivado também integralmente de Espeusipo a lista dos contrários de Met. 986a22, ainda que simplesmente como a mais bem acabada lista que estava à sua disposição. Sem negar, portanto, a possibilidade de existirem outras listas que podiam ser originalmente pitagóricas. 
(1989: 186) considerarem bastante provável que Aristóteles esteja tentando diminuir de alguma forma a originalidade da ideia de métbexis platônica, apontando ao mesmo tempo para Aristoxeno, cujo antagonismo com Platão é bastante atestado.

De fato, um testemunho deste último reproduz a mesma ideia da imitação: Pitágoras "assemelha todas as coisas aos números" (fr. 23, 4 Werli). 30

Em verdade, o próprio Aristóteles refere-se novamente a algo bastante parecido ao conceito de mímesis em outras passagens em que se refere aos números pitagóricos e utiliza termos ligados ao campo semântico da semelhança:

Dado que justamente nos números, mais que no fogo, na terra e na água, eles achavam que viam muitas semelhanças com as coisas que são e que se geram; por exemplo, consideravam que determinada propriedade dos números era a justiça, outra a alma e o intelecto, outra ainda o momento e tempo oportuno e, em poucas palavras, de modo semelhante para todas as outras coisas (Met. 985b27-32). ${ }^{31}$

É, portanto, nesse sentido das homoiómata que deve ser compreendida a referência à mímesis. 32

Também a citação acima das pedrinhas de Eurito, em outra página de Metafísica (Met. 1092b8-13), pode ser remetida para o interior desse mesmo campo semântico da semelhança e da imitação. Alexandre de Afrodísia, por sua vez, em seu comentário à Metafísica de Aristóteles, explicita o raciocínio que teria levado à definição da semelhança da justiça com o número quatro:

Partindo do pressuposto de que o caráter específico da justiça seja a proporcionalidade e a igualdade, e percebendo que esta propriedade

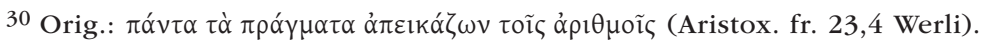

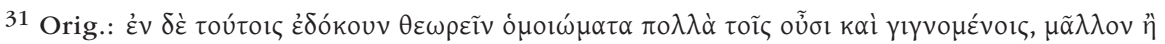

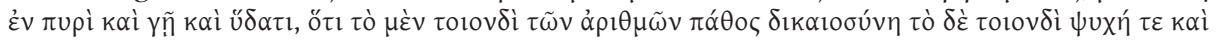

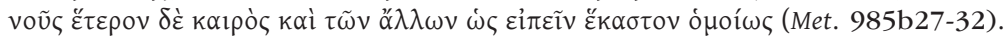

32 Cf. para esta aproximação Centrone (1996: 107-108). 
está presente nos números, por este motivo os pitagóricos diziam que a justiça é o primeiro número quadrado; [...] Este número alguns diziam que fosse o quatro, pois é o primeiro quadrado, e também porque é dividido em partes iguais e é igual ao produto destas (de fato, é duas vezes dois) (In Metaph. 38, 10 Hayduck). 33

Burkert (1972: 44-45) anota que esse conceito de mímesis deve corresponder, senão na terminologia utilizada por Aristóteles, ao menos em seu sentido, a uma teoria pré-socrática, e não já platônica. A ideia fundamental da magia ou da medicina hipocrática é aquela de uma correspondência "de mão dupla" entre duas entidades (o corpo e o cosmo, a arte e a natureza). No caso específico, simplesmente reafirmaria uma correspondência, uma imitação do cosmo com o número e vice-versa. O mesmo Cornford (1922) considerava essa ideia da imitação muito antiga, por causa exatamente de sua característica mística, que o comentador aproxima diretamente, por meio da etimologia (mímos = ator), aos cultos dionisíacos e ao fato de os protagonistas dos cultos desempenharem o papel do próprio deus:

A esta altura "semelhança com deus" equivale a uma identificação temporária. Induzida pelos sentidos orgiásticos, pelo êxtase báquico ou pelas festas sacramentais órficas, é o aperitivo da reunião final. No pitagorismo, a concepção é mitigada, apolinizada. O sentido não é mais êxtase, ou sacramento, mas teoria, contemplação intelectual da ordem universal (Cornford 1922: 143). 34

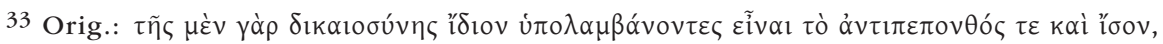

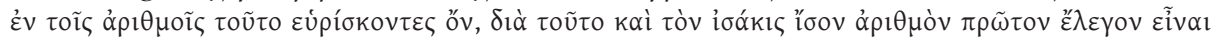

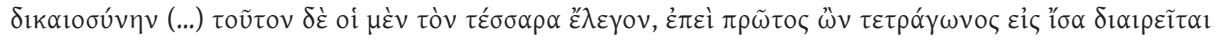

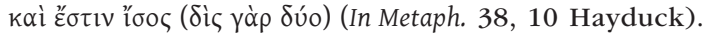

34 Orig.: At that stage 'likeness to God' amounts to temporary identification. Induced by orgiastic means, by Bacchic ecstasy or Orphic sacramental feast, it is a foretaste of the final reunion. In Pythagoreanism the conception is toned down, Apollinized. The means is no longer ecstasy or sacrament, but theoria, intellectual contemplation of the universal order. Concorda com a possibilidade desta origem "mística dos números" também Casertano (2009: 67). 
Contra essas hipóteses, todavia, joga o fato de Aristóteles, a bem ver, não indicar a imitação de prágmata, e sim realidades abstratas como a justiça, o tempo etc. ${ }^{35}$ De toda forma, ainda que se possa conceder que Aristóteles esteja se referindo aqui a uma doutrina do protopitagorismo, de estilo acusmático, é certamente o caso de anotar que, na página sucessiva (Met. 987b29), exclui veementemente que os pitagóricos concordem com Platão com o papel de méthexis atribuído aos números por este último.

A "precisação" de Aristóteles sugeriria, neste caso, que uma intenção polêmica antiacadêmica devesse ser talvez a mais apropriada para explicar este apax da referência à mímesis. 36

É possível concluir que as três versões da doutrina "tudo é número" (aquela da identificação, dos números como princípios e esta última da imitação) aparecem articuladas de maneira imperfeita e, no limite, contraditória, em sua tradição no interior da obra aristotélica.

Todavia, é bastante significativo que Aristóteles não mencione em algum momento que as três diferentes lectiones do "tudo é número" devam pertencer a diferentes grupos ou momentos no interior do pitagorismo. De certa forma, parece ainda considerá-las, senão coerentes entre si, ao menos conciliáveis, e as refere todas, indistintamente, aos "assim chamados pitagóricos".

O reconhecimento disso levou diversos autores a adotarem soluções conciliatórias para o problema. In primis, o próprio Zeller. Ainda que considerasse que o testemunho de Aristóteles devesse ser tomado com todos os cuidados do caso, sua proximidade histórica com as doutrinas pitagóricas deveria garantir, de certa forma, a procedência da especial articulação destas neste contidas.

Assim, para Zeller:

35 Burnet $(1908,119)$, por outro lado, alerta que não se devem levar a sério essas passagens: They are mere sports of the analogical fancy.

36 Este é também um dos motivos que obriga a descartar a hipótese de Burnet (1908: 355) e Taylor (1911:178s), retomada também por Delatte (1922: 108ss.), pela qual o pitagorismo seria o inventor da teoria das formas platônicas. Assim, Burnet: the doctrine of 'forms' (eíde, ideíai) originally took shape in Pythagorean circles, perhaps under Sokratic influence (1908: 355). 
Não há dúvida de que na exposição de Aristóteles devemos procurar antes de tudo e somente sua própria maneira de ver, e não um imediato testemunho da realidade de fato, todavia mesmo neste caso [da teoria numérica] tudo fala a favor de um reconhecimento do fato de que esta sua maneira de ver estivesse fundamentada sobre um direto conhecimento da efetiva conexão das ideias próprias do pitagorismo (Zeller e Mondolfo 1932: 486). 37

Frank (1923: 77 n196) e Rey (1933: 116), exatamente para exorcizar a possibilidade de incompatibilidade delas, imaginam a possibilidade de Aristóteles ter compreendido as três versões como derivadas logicamente uma da outra.

De maneira especial, Rey elabora uma proposta conciliatória entre a versão dos números serem as coisas e aquela dos números imitarem as coisas: os números seriam as coisas quando se considera sua natureza e imitariam as coisas quando se considerassem suas propriedades (1933: 356ss.). 38

Mais elaborada é a argumentação conciliatória de Raven (1948: 4365), pela qual:

Supor, como muitos comentadores parecem supor, que Aristóteles ficou totalmente confuso sobre isso não somente levaria para a porta dele um grande peso, mas também demoliria, com isso, a base central sobre a qual qualquer reconstrução confiável do pitagorismo deve ser erigida (Raven 1948: 63). 39

37 Orig.: non v'há dubbio che nella esposizione di Aristotele noi dobbiam cercare anzi tutto e soltanto il suo proprio modo di vedere, e non un'immediata testimonianza sulla realtà di fatto. Tuttavia anche in questo caso tutto parla in favore di un riconoscimento del fatto che questo suo modo di vedere si fondasse su una diretta conoscenza della effettiva connessione d'idee propria del pitagorismo.

38 Para críticas à proposta de Frank e Rey, cf. tanto Cherniss (1935: 386) como Burkert (1972: 44 n86).

39 Orig.: To suppose, as so many scholars appear to suppose, that Aristotle was hopelessly confused about it, is not only to lay a very serious charge at his door, but also, incidentally, to demolish the main basis upon which any reliable reconstruction of Pythagoreanism must be erected. 
Em aberta polêmica com Cornford (1923: 10) e sua ideia de que Aristóteles estaria aqui apresentando, sem distingui-los, dois momentos do pitagorismo (um primeiro ligado à ideia de uma materialidade dos números, um segundo em que os pitagóricos estariam mais preocupados com a composição numérica da realidade), Raven propõe, ao contrário, uma radical indissociabilidade do uso dual dos números no interior do pitagorismo antigo. ${ }^{40}$

Aristóteles estaria assim simplesmente recebendo deste último uma concepção da natureza como igual aos números, no sentido de constituir uma agregação de unidades espaciais (1948: 62). Contudo, os números não constituiriam somente a matéria da realidade, e sim estariam também à origem das diferenças qualitativas que distinguem uns objetos materiais dos outros. Somente assim seria possível pensar tanto a versão da imitação como aquela dos números dos princípios como articulada com a primeira versão. ${ }^{41}$

É certamente possível ao menos afirmar que a ideia de mímesis atribuída aos pitagóricos por Aristóteles não tem muito a compartilhar com a paralela concepção platônica de mímesis pela qual as realidades fenomênicas imitam, no sentido de serem feitas "à semelhança de", outras realidades suprasensíveis de nível ontológico superior, isto é, as formas. E, se essa observação é correta, o que Aristóteles deve atribuir aos pitagóricos, quando fala da mímesis, não pode ser outra coisa senão uma genérica correspondência entre as coisas e as relações numéricas que as explicam, que as tornam inteligíveis.

Resume bem a questão Casertano:

Inteligibilidade imanente, portanto, e não trascendente às coisas mesmas. É por este motivo que as fórmulas pitagóricas "as coisas são números" e "as coisas assemelham-se aos números" não estão em contraste; ao contrário, são expressões de uma mesma intuição fundamental,

40 Cornford afirma de fato que: Aristotle himself draws attention to the two diverse ways of making numbers 'the causes of substances and being', which, in my view, are characteristic of the two different schools of Pythagoreans (Cornford 1923: 10).

41 Sobre a mesma ideia, cf. também Guthrie (1962: 230s). 
que é aquela da homogeneidade entre realidade e pensamento, entre as leis da realidade e as leis do pensamento: compreender as coisas é essencialmente espelhá-las, reproduzir em nível mental aquela estrutura, plenamente inteligível, que é própria da realidade material (Casertano 2009: 65). ${ }^{42}$

Apesar de estar clara, portanto, aquela que podia ter sido a intuição fundamental dos pitagóricos, isto é, a possibilidade de compreender a natureza pelos números, o fato é que a tentativa de conciliação aristotélica entre as diferentes versões da teoria não pareceu, de toda forma, bem-sucedida.

Se, além do mais, considera-se que a versão principal da doutrina pitagórica, aquela da identidade do número com as realidades, obedece diretamente à intenção polêmica de Aristóteles com o platonismo, levando-o a considerar o árithmos pitagórico como causa material, em oposição à militância platônica em favor da causa formal (Cherniss 1935: 360), torna-se difícil definir indiscutivelmente qual seria o valor historiográfico da doutrina pitagórica do "tudo é número". 43

Difícil, mas não impossível.

\section{UMA PRIMEIRA SOLUÇÃO: UMA REDUÇÃo ARISTOTÉLICA}

A esta questão do valor da afirmação aristotélica "tudo é número" como descrição válida da filosofia pitagórica foram propostas duas soluções.

42 Orig.: Intelligibilità immanente, appunto, e non trascendente le cose stesse. Ecco perchè le formule pitagoriche 'le cose sono numeri' e 'le cose somigliano ai numeri' non sono in contrasto, ma sono espressioni di una medesima intuizione fondamentale, che è quella dell'omogeneità tra realtà e pensiero, tra leggi della realtà e leggi del pensiero: capire le cose è essenzialmente rispecchiarle, riprodurre a livello mentale quella struttura, pienamente intelligibile, che è propria della realtà materiale.

43 Centrone (1996: 105) anota neste sentido que l'interesse [di Aristotele] per il pitagorismo, $i$ cui pregi in definitiva consistono solo nell assenza dei difetti propri della filosofia dei platonici, non è soverchiante, ed è anzi determinado proprio dalle affinitità con le dottrine platoniche. 
A primeira parte da contestação radical da validade do testemunho aristotélico, chegando a simplesmente negar que ao protopitagorismo corresponda uma doutrina do número tout court. Os motivos para essa contestação não faltam e podem ser resumidos, fundamentalmente, no paradoxo de uma doutrina que, ainda que amplamente atestada na principal fonte para o pitagorismo antigo, isto é, Aristóteles, todavia não parece encontrar confirmação nos testemunhos mais antigos.

É desse paradoxo que Zhmud (1989), no artigo citado anteriormente, começa sua argumentação. É certamente o caso de segui-la passo a passo.

O horizonte em que se insere a reflexão de Zhmud é aquele de uma história da tradição que define a categoria pitagorismo a partir de uma identificação doutrinária. Nesse sentido, a preocupação fundamental do autor é aquela de contrastar a impressão que o texto aristotélico parece deixar de que a definição de "alguém que fala de números" seria a melhor definição de um pitagórico. O critério identitário revelaria quanto de circular, quanto de petitio principii, haveria nessa utilização do critério dos números para identificar um pitagórico (Zhmud 1989: 272).

De fato, apesar de diversas tentativas a esse respeito, nenhum historiador - afirma Zhmud - teve sucesso na busca de qualquer doutrina sobre os números nas fontes pré-aristotélicas sobre o pitagorismo (Zhmud 1989: 272).

A partir desses argumentos, Zhmud admite somente duas possibilidades de solução da questão: ou a expressão "tudo é número" pertenceria a um antigo e secreto ensinamento do "divino" Pitágoras, do qual todavia não se teria alguma referência nas fontes mais antigas (e que, portanto, deveria ter sido revelado diretamente a Aristóteles); ou esta expressão, assim como a doutrina a ela colegada, não seria de fato de alguma maneira uma doutrina pitagórica. ${ }^{44}$

${ }^{44}$ Assim comenta Zhmud: If we do not wish to think that the central dogma of Pythagorean philosophy was secret, then it would be quite reasonable to suppose: either this dogma was not central, or it was not a dogma at all. Only very few of those who write about Pythagorean philosophy arrive at such a paradoxical conclusion (Zhmud 1989: 275). Sobre a prática do segredo na comunidade pitagórica mais antiga, cf. Cornelli (2011: 92ss). 
Esta segunda possibilidade corresponde a uma já clássica posição de Burnet, pela qual "o próprio Pitágoras não teria deixado nenhuma doutrina desenvolvida sobre o tema, enquanto os pitagóricos do quinto século não se interessaram em acrescentar nada deste tipo à tradição da escola" (1908: 119). 45

Ainda que não deva maravilhar, depois dos estudos de Cherniss, que o método "historiográfico" aristotélico tenha a liberdade de operar reformulações e traduções em seus mesmos termos das doutrinas de seus predecessores, é todavia o caso de perguntar-se o que levaria Aristóteles a postular exatamente essa doutrina do "tudo é número", que, na forma atual, não devia ser pitagórica.

O que foi dito até aqui pode já sugerir um primeiro esboço de resposta a essa pergunta: de certa forma, Aristóteles é confrontado com grande diversidade de fontes pitagóricas, tanto antigas (Hipaso) quanto a ele mais próximas (Ecfanto, Filolau, Arquitas). Contudo, para as finalidades internas à Metafísica de Aristóteles, conforme se viu acima, essa pletora de pitagóricos precisava ser reconduzida a um denominador comum, a uma escola que, de certa forma, coubesse no percurso histórico-teorético que Aristóteles pretendia desenhar em sua doxografia.

Sem essa redução aos mínimos termos teóricos, de fato, seria impossível inserir os pitagóricos no interior do modelo agônico pelo qual Aristóteles descreve a história dos predecessores (Cherniss 1935: 349). Somente dessa forma, por exemplo, o arché pitagórico encontra seu lugar de antagonista da causa material jônica. Ao mesmo tempo, todavia, exatamente certa imprecisão terminológica das fontes pitagóricas (da qual, como vimos, Aristóteles parece reclamar em Met. 1092b1-13) permite a inserção do número pitagórico como, ao mesmo tempo, precursor da causa formal platônica.

Vale pensar se a reclamação de Aristóteles não seja um blefe, pois se o número já não tivesse esta dupla valência, bem, Aristóteles a teria

45 Orig.: Pythagoras himself left no developed doctrine on the subject, while the Pythagreans of the fifth century did not care to add anything of the sort to the school tradition. Da mesma ideia também Gigon (1945: 142). 
provavelmente inventado, pois ela calça à perfeição no interior de seu modelo doxográfico.

Assim, a postulação de "tudo é número" teria sido a solução de um problema de Aristóteles e, de certa forma, o início de uma longa tradição que, a partir de Zeller (Zeller e Mondolfo 1938: 435), reduziu a categoria pitagorismo aos estreitos limites dessa doutrina metafísica.

\section{UMA SEGUNDA SOLUÇÃO： FILOLAU}

É a partir desse impasse bermenêutico deixado pela solução acima, isto é, da invenção aristotélica de uma categoria bistoriográfica ("os assim chamados pitagóricos") e de um denominador comum doutrinário para esta ("tudo é número"), que toma corpo uma segunda solução ao problema. Essa segunda solução empreende especificamente uma reavalição das fontes pitagóricas do século $\mathrm{V}$ aEC em busca de possíveis referenciais históricos da expressão “assim chamados pitagóricos” de Aristóteles.

A começar de uma observação importante: a grande quantidade de referências ao pitagorismo e à teoria dos números em Aristóteles revela um fato inquestionável: Aristóteles devia mesmo possuir diversos textos pitagóricos, por assim dizer, na mesa dele. ${ }^{46}$

Algumas passagens de Aristóteles sugerem que a certeza com a qual considera inquestionáveis certas afirmações sobre os pitagóricos dependa exatamente do fato de ele ter acesso a uma suficientemente ampla literatura de autoria deles. É o caso da discussão sobre se os pitagóricos considerassem o mundo gerado ou não. Aristóteles afirma ser impossível duvidar disso:

"Se os pitagóricos admitem ou não um processo de geração dos entes eternos, é questão sobre a qual não resta dúvida” (Met. 1091a13). ${ }^{47}$

\footnotetext{
46 Concordam com isso Burkert (1972: 236), Zhmud (1989: 281), Huffman (1993:57) e Centrone (1996:105).

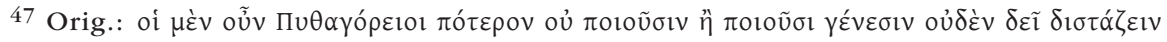
(Met. 1091a13).
} 
Da mesma forma, Aristóteles demonstra ter absoluta certeza de que os pitagóricos não haviam tratado dos corpos sensíveis: "Não disseram absolutamente nada sobre o fogo, nem sobre a terra, nem sobre os outros corpos" (Met. 990a16-17). ${ }^{48}$

Além disso, a tradição informa-nos que Aristóteles dedicou ao menos dois livros aos pitagóricos como tais, sem contar as obras dedicadas especificamente a Pitágoras ou a um o outro pitagórico específico, como teria sido o caso de Arquitas. ${ }^{49}$

A resposta à pergunta sobre quais seriam esses "assim chamados pitagóricos” aos quais Aristóteles quer atribuir a doutrina dos números depende, assim, em boa parte da possibilidade de identificação desses livros. Contudo, os únicos livros dos quais temos notícia, pela tradição, são aqueles de Filolau e Arquitas. Como Aristóteles parece tratar deste último à parte, e não debaixo do guarda-chuva dos assim chamados, o mais provável é que sejam exatamente os livros de Filolau os textos pitagóricos que estavam na mesa de Aristóteles.

Este segundo caminho de solução seria representado, portanto, por Filolau.

É o caso de anotar, ainda, que não deve maravilhar, que não se chegou antes a essa mesma conclusão metodológica, pela qual a solução do problema da atribuição da doutrina "tudo é número" fosse o estudo dos fragmentos de Filolau.

Grande parte da tradição, a começar pelo próprio Cherniss (1935: 386), conforme se acenou acima, não pôde seguir nesse sentido, pois, na esteira de Frank (1923), considerava os textos de Filolau espúrios. Somente a partir da "redescoberta" do valor de parte essencial dos fragmentos de Filolau, já com Burkert (1972, 218ss.) e depois com Huffman (1988; 1993), é que foi possível trilhar esse caminho.

A recente reavaliação do valor histórico dos fragmentos de Filolau permite, portanto, novos passos hermenêuticos anteriormente impossí-

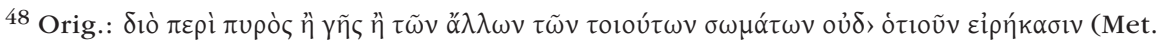
990a16-17).

49 Para ampla discussão dessas obras e todas as referências ao caso, cf. Burkert (1972, $29 \mathrm{n} 5)$. 
veis. Contudo, responder à pergunta sobre quem seriam os pitagóricos na obra de Aristóteles com Filolau e, portanto, com o pitagorismo do V século aEC, continua carregando sérias dificuldades para a identificação aristotélica dos pitagóricos como aqueles pelos quais "tudo é número"; por um simples motivo: mesmo em Filolau não há referência explícita a essa doutrina do "tudo é número".

\section{OBSERVAÇÕES FINAIS}

Por motivos de economia de espaço não poderemos entrar no labirinto da questão filolaica para avaliar em que medida uma solução dessa questão possa se apresentar também como solução para a atribuição ao pitagorismo antigo de alguma teoria numérica. Procurei avaliar esta questão em outra sede (Cornelli 2013), e remetemos o leitor que quiser acompanhar os detalhes desta segunda solução para a discussão lá contida. 


\section{Diofanto DE ALEXANDRia \\ E OS PRIMórdios da Álgebra}

\section{Diophantus and the Beginnings of Algebra}

Carlos Gamas

Universidade de Coimbra

\section{RESUMO}

Este capítulo tem como objectivo avaliar a natureza das investigações matemáticas de Diofanto no contexto das potenciais origens da Álgebra e torná-las compreensíveis enquanto enquadradas no contexto de uma tradição oriental-ocidental mais antiga, por um lado, e, por outro lado, no contexto da sua posterior recepção pelo Islão. É de salientar que a Álgebra atinge a sua autonomia e maturidade no mundo islâmico e que Diofanto e a tradição grega permanecem como precursores da Álgebra. Ainda assim, as investigações matemáticas de Diofanto e o seu aprofundamento no mundo islâmico formatam o modo como Fermat procedeu à sua leitura da tradição e inspiraram o famoso 'último teorema de Fermat'.

Palavras-Chave: Diofanto, Al-Khwarismi, Álgebra, Alexandria: Museu e Biblioteca, Casa da Sabedoria de Bagdad.

\section{AbSTRACT}

This chapter aims to consider the nature of Diophantus' mathematical research in what concerns the potential origins of Algebra and to make it understandable in the context of a former eastern-western tradition, as much as in the context of the latter Islamic reception. It is to underline that Algebra attains its autonomy and maturity in the Islamic world and that Diophantus and the Greek tradition stay as one of the forerunners of Algebra. Anyway Diophantus' mathematical research and its development in the Islamic world shappen the way how Fermat made his lecture of the tradition and inspired his famous last theorem

KEY WORDS: Diophantus, Al-Khwarizmi, Algebra, Alexandria Museum and Library, Bagdad House of Wisdom. 
Da figura de Diofanto pouco mais se sabe em concreto do que a idade da sua morte: 84 anos. A informação é dada por um poema da Antologia Grega, sob a forma de adivinha matemática, que se diz ter constituído o epitáfio do matemático alexandrino. Sabe-se que escreveu uma Aritmética, em treze livros, de que só chegaram seis até nós, no original grego, e já nos nossos dias descobriu-se uma versão árabe de quatro desses seis livros $^{1}$, um tratado Sobre números poligonais, de que resta um fragmento, e Porismos, obra perdida.

Interessa-nos focar Aritmética, de cujo conhecimento dos seis primeiros livros em versão grega deu nota em 1463 o matemático renascentista Johann Müller, mais conhecido pelo nome que adoptou, Regiomontanus. Financiado por um Mecenas, Regiomontanus fundou uma imprensa e um pequeno observatório em Nuremberga. Sobreviveu uma lista dos livros que ele esperava vir a editar, entre os livros da lista constam traduções de Arquimedes, de Apolónio, de Héron, de Ptolomeu e de Diofanto.

Já relativamente recentemente foi descoberta uma tradução árabe dos quatro primeiros livros deste último.

Sobre a época em que o matemático Diofanto viveu não há certezas aliás, testemunhos antigos de diversas proveniências situam-no em épocas diferentes, de acordo com as diversas opiniões, mas o mais provável, e aceite pela maior parte de estudiosos de História da Matemática, é que este matemático do contexto alexandrino tenha atingido o seu período de actividade mais intensa em meados do séc. III p. C. (ca. 250)².

Estamos, assim, a meio milénio dos considerados tempos áureos da Cultura Alexandrina, que tomou fôlego à volta, sobretudo, do Museu e da Biblioteca, fundados no início do séc. III a. C. ${ }^{3}$, e em cujos primórdios se desenvolveu a actividade de Euclides, de Apolónio de Perga, ou do siracusano Arquimedes que, ainda que tivesse desenvolvido a sua actividade principal na sua terra natal, manifestou ligações a Alexandria, - «the

\footnotetext{
1 Katz 1993: 163.

2 Heath, na sua clássica obra sobre as origens da Álgebra (1885), dedica todo um capítulo à discussão de testemunhos sobre a datação de Diofanto, que vê como quase contemporâneo de Papo.
}

3 Marlowe 1971: 67 sqq. 
three mathematical giants of the third century", como lhes chama Eves ${ }^{4}$ - ou de Eratóstenes de Cirene, de Aristarco de Samos, sábios vindos de culturas a oriente, de culturas do espaço do Egipto ou da velha Grécia, ou ainda de Hiparco de Niceia, na Bitínia (séc. II a. C.).

A confluência multicultural de gente familiarizada com a tradição do saber de matemáticos, astrónomos, geógrafos das suas terras de formação de origem, que a confrontava, discutia, ampliava e lhe dava novo avanço no círculo do Museu e da Biblioteca tornou propício esse brilho de criatividade de pensamento, em que se associou o repensar das tradições, a aplicação prática da ciência teórica e o espírito de recolha, compilação, ordenação e aprofundamento científico (note-se que os Elementos de Euclides vêm nessa linha, apoiada numa rica tradição) 5 .

O séc. III da era cristã deixa perceber que a actividade de investigação matemática já tinha vindo a perder fulgor e alento. Ela vai deixando progressivamente espaço para a actividade de comentaristas e compiladores futuros e anuncia o declínio de Alexandria e o passar de testemunho científico para outros contextos culturais. No entanto, é nessa mesma época que se destaca um dos espíritos matemáticos mais brilhantes, cuja actividade de investigação e cujos escritos tanta importância viriam a ter no futuro da investigação matemática e do desenvolvimento da Álgebra: Diofanto.

Em vários estudos dedicados à História da Álgebra Diofanto vem apodado como 'o pai da Álgebra'. Há, porém, que relativizar este juízo, com um olhar a Oriente - um olhar que antecede a cultura grega e outro olhar posterior a ela.

Hodgkin recorre à lúcida caracterização de Joseph e chama a atenção para as perspectivas pelas quais se lê comummente a História da Matemática e aquela por que ela deve ser entendida, nomeadamente ${ }^{6}$ :

\footnotetext{
${ }^{4}$ Eves 1990: 171

5 Há notícia de que Têudio de Magnésia, discípulo de Eudoxo de Cnidos e de Platão, na Academia, tenha escrito uns primeiros Elementos, e Hipócrates de Quios, no séc. V a. C., também uns Elementos, que Euclides conheceria bem: Gamas 2013: 48.

6 Hodgkin 2005: 13.
} 
1-Uma tradicional 'trajectória eurocêntrica', já ultrapassada, mas que ainda se sente, por vezes, em alguns textos, segundo a qual o saber grego foi 'redescoberto' pelo Renascimento ${ }^{7}$;

2-Uma variante melhorada da primeira, a que Hodgkin e Joseph chamam 'modified Eurocentric trajectory': a Grécia assimila em parte conhecimentos do Egipto e da Babilónia, mas após o declínio da ciência grega o mundo islâmico preserva-a até à sua reintrodução em espaço ocidental no Renascimento;

3-A 'trajectória alternativa', proposta por Joseph: dentro das várias ramificações na transmissão, o papel central do mundo islâmico na Idade Média, como um centro cultural marcado pela seu contacto com a Índia, China e Europa, é flagrante. Esse centro de cultura é receptor, inovador e transmissor.

Esta última alternativa representa uma chave de compreensão para a ciência na Antiguidade, no que aqui interessa, para a Matemática e, mais especificamente, para Diofanto e para a recepção e continuidade das suas investigações e actividade..

De facto, do tempo da Mesopotâmia unificada sob o império do imperador Sargão (séc. 24 a. C.), há testemunhos, em placas de argila de escrita cuneiforme, do desenvolvimento de um sistema numérico, e do período da Antiga Babilónia (séc. XIX a. C.), governada por Hamurabi e pela dinastia que este governante fundou datam textos matemáticos sofisticados, conservados em placas de argila.

É mais que provável que no Egipto as instituições de administração do poder tivessem recorrido a cálculos matemáticos para efeitos de controle social e económico, mas os testemunhos são mais escassos, devido à fragilidade do material de escrita utilizado - o papiro ${ }^{8}$. Ainda assim, o

7 Um dos clássicos exemplos desta leitura é o livro de Klein 1968, originalmente publicado em alemão em edição de 1935 .

8 Hodgkin 2005: 15-17. Sobreviveram dois papiros matemáticos de importância e uns quantos pequenos fragmentos. 
Papiro Rhind contém cálculos com uma variável, que facilmente se podem traduzir numa equação simples de primeiro grau?

Os Babilónios desenvolveram o sistema sexagesimal, que os Gregos virão a usar na astronomia e geometria e chegaram à noção de 'incógnita', que aparece na enunciação de problemas a que Hodgkin chama 'de segundo grau', próximos das equações de segundo grau.

A fórmula de resolução destas, como se sabe, é obtida pela investigação islâmica. Babilónica é, também, uma pequena placa com a representação da raiz quadrada de 2 (placa YBC7289) ${ }^{10}$.

O tipo de problemas enunciados, ainda que inspirado no quotidiano (número de tijolos de um muro, peso, medida, proporção entre largura e comprimento do muro para encontrar os reais valores desta largura e comprimento), apontam para a existência de um cálculo autonomizado da sua aplicação, por puro interesse na própria operação de cálculo.

Em contexto de cultura grega à volta de Alexandria, já no séc. I p. C., Nicómaco de Gerasa (cidade situada no actual território da Jordânia) escreve uma Introdução à Aritmética. Insere-se numa nova tendência - a de recuperação do Pitagorismo para a sua própria teoria dos números. Nota Katz"11 que, para além de Euclides, livros VII-IX, esta é "the only extant number theory work from Greek antiquity». Mas, segundo o mesmo autor, a atenção dada à discussão de questões elementares aponta para uma obra para iniciantes.

A Aritmética de Diofanto situa-se num outro plano, de avanço e aprofundamento do trabalho desenvolvido por Babilónios e Egípcios no campo dos problemas e das respectivas soluções sob forma de equações, criando uma linguagem simbólica para quantidades variáveis, na formulação dessas equações. Assim, Diofanto contribui, de forma decisiva, para dar consistência a um saber algébrico que nos legou, a oriente, os seus primeiros testemunhos muitos séculos antes ${ }^{12}$.

\footnotetext{
9 Heath 1981: 440-441.

10 Veja-se Hodgkin 2005: 25, fig. 6.

11 Katz 1993: 157.

12 Observa Klein 1968: 127: "That the science of Diophantus exhibits certain non-Greek traits can hardly be denied".
} 
Eves $^{13}$ define o tratado como "an analytic treatment of algebraic number theory and marks the author as a genius in this field".

Não se esqueça que os Gregos representavam os números por caracteres do seu alfabeto e por junção combinada desses caracteres. Mas a inovação de Diofanto consiste em utilizar símbolos que, na verdade, começam por ser abreviaturas de termos . É o caso, a título de exemplo, de ऽ como abreviatura de arithmos ('número'), M, como abreviatura de monas ('unidade'). Mas Diofanto vai mais longe, escolhendo o caracter $\chi$ para assinalar inversos. Retomando o exemplo de Katz: $\Delta^{\Upsilon \chi}$ representava 1/x2.

Diofanto está na posse do conhecimento das regras de multiplicação de expressões algébricas que envolvam subtracções (menos por menos dá mais, menos por mais dá menos), o que não envolve o conhecimento de números negativos, não existente à época ${ }^{14}$.

A parte que nos chegou da Aritmética de Diofanto mostra que a obra não é propriamente um tratado de Álgebra, mas uma colecção de problemas para cuja solução se recorre à Álgebra; de facto, Diofanto formula e procura solucionar cerca de 130 problemas de diversa natureza. As soluções levam à formulação de equações de primeiro e de segundo grau. Um caso ocorre que pede solução por uma equação de grau 3.

No livro I encontramos equações determinadas com uma variável. Os restantes livros apresentam equações indeterminadas de segundo grau e duas ou três variáveis. Note-se, no entanto, que Diofanto não descobriu propriamente uma fórmula geral de resolução de equações de segundo grau.

A cessação de actividade cultural e científica no âmbito do Museu e da Biblioteca de Alexandria deu-se do séc. IV para o séc. V da era cristã, embora essa fosse a etapa final de uma decadência progressiva.

O cruel assassinato às mãos de fanáticos cristãos da erudita Hipácia, por sinal comentadora dos quatro primeiros livros de Diofanto, que copiou (e deve ser esta versão que foi posteriormente traduzida para árabe), e filha do último bibliotecário de Alexandria, Téon, também matemático-

\footnotetext{
13 Eves 1990: 180.

${ }^{14}$ Katz 1993: 163-164.
} 
-comentador, toma quase um carácter simbólico, de fim uma tradição cultural cultivada ali e herdeira de outras tradições mais antigas ${ }^{15}$.

Em boa verdade, o centro de convergência cultural deslocar-se-á, em breve, para oriente. O fenómeno 'Islão', surgido no séc. VII, com a rápida propagação e conquista religiosa de adeptos e de poder, por parte de Maomé, conhece uma fase de expansionismo enorme já no séc. VII.

Todo o Próximo Oriente, incluindo Egipto, Pérsia, antiga Mesopotâmia e estendendo-se até tocar a Índia, é congregado sob o domínio islamita. Esta primeira fase é caracterizada por um espírito de tolerância e de coexistência comunicativa entre populações e intelectuais das três 'Religiões do Livro'.

Damasco e depois Bagdad, por acção dos califas da dinastia Abássida, convertem-se, deste modo, em centros culturais preponderantes.

No séc. VIII as gerações sucessivas de califas abássidas Abu Al-Mansur, Mohammad Al-Mahdi e Al-Ma'moun dedicam-se a coleccionar manuscritos antigos de ciência. Al-Mahdi cria uma biblioteca para os receber, em Bagdad, e seu filho Al-Ma'mun (séc. VIII-IX) expande essa biblioteca e converte-a, à maneira da Biblioteca de Alexandria, num centro vivo de convergência e diálogo de saberes e de actividade de preservação e transmissão.

De entre os manuscritos reunidos na biblioteca abássida consta uma parte oriunda de Alexandria. Certamente que entre eles estariam os quatro primeiros livros da Aritmética de Diofanto, comentados por Hipácia. Isto é o que nos leva a concluir o facto de os quatro livros em versão árabe, descobertos não faz muito tempo, divergirem em alguns pontos dos dos manuscritos gregos encontrados no Renascimento.

Este centro de saberes e de investigação científica recebeu o nome de Casa da Sabedoria e viria a perdurar por cerca de duzentos anos. Aí foi traduzido, para árabe, o Almageste de Ptolomeu. Para aí convergem, espontaneamente ou por convite dos califas, sábios da Pérsia, matemáticos da Índia, intelectuais cristãos, judeus e outros. Aí se fala árabe (como língua franca), farsi, sírio, aramaico, hebraico, grego, latim (o antigo

15 Veja-se Gamas 2013: 47-53. 
sânscrito era usado apenas para manusear antigos manuscritos indianos de astronomia e de matemática).

A tradição da ciência grega antiga e alexandrina representa um filão, a convergir para um caudal alimentado por outras fontes. O resultado deste processo é uma ciência, no caso da Matemática, um saber matemático enriquecido, apurado e afinado, numa linguagem depurada e mais precisa, que propicia o cálculo e a abstracção, que aspira a soluções e verificações universais. A Matemática árabe adopta e transmite o sistema decimal, importado da Índia, em concomitância com o sexagesimal, utilizado na medição do tempo e na Geometria.

Assim, é nesta primeira fase da Casa da Sabedoria que aí vamos encontrar o famoso matemático de origem persa Muhammad Ibn Musa Al-Khwarismi.

Entre várias obras de astronomia e de matemática, Al-Khwarismi escreveu um tratado de aritmética que se perdeu - Livro sobre Adição $e$ Subtracção segundo o Método dos Indianos. Restam traduções medievais para latim (séc. XII). No texto o autor introduz nove caracteres para indicar os dígitos que, por isso, receberam o nome derivado do seu 'algarismo' - e um círculo para indicar o 'zero'16. Esta é uma utilíssima invenção indiana que vem resolver um problema de registo numérico sentido desde sempre.

Al-Khwarismi é, além disso, autor de um tratado escrito por volta de 825, intitulado, no original Hisab Al-jabr Wa Al Muqqabala, traduzível por 'Cálculo por Restauração e Comparação' e de onde deriva a designação 'Álgebra'. O tratado chegou até nós ${ }^{17}$ e evidencia a importância da investigação de Al-Khwarismi, considerado como o verdadeiro fundador da Álgebra, ainda que se reconheça nele o contributo, não explícito, todavia, de Diofanto.

\footnotetext{
16 Katz 1993: 225.

17 Foi traduzido por F. Rosen em 1831, publicado em Londres e reimpresso em Olms, em 1986: vide Hodgkin 2005: 103.
} 
O matemático islamita abandonou definitivamente uma dimensão grega de "álgebra retórica" - para usar a expressão, entre outros, de Eves ${ }^{18}$ - e encontrou na tradição indiana o suporte de linguagem numérica mais adequado. O suporte encontrado permitiu-lhe chegar a soluções mais gerais de resolução de equações de segundo grau. A preocupação por sistematizar e definir ('raiz', 'quadrado', número') é visível' ${ }^{19}$.

A sua obra teve continuadores e abriu caminhos para o aprofundamento da Álgebra, No século seguinte o árabe Al-Uqlidisi prosseguia, na Casa da Sabedoria, as suas investigações algébricas e transcrevia, simultaneamente, Euclides - tarefa a que deve o seu nome. O seu trabalho com o texto euclidiano abriu-lhe perspectivas sobre a possibilidade ou necessidade de tradução numérica das proposições euclidianas.

Ainda no séc. IX o sábio islamita Thabit Ibn Qurra trabalhou sobre matemáticos gregos, expandindo os problemas por eles formulados. Ibn Qurra traduziu, comentou e escreveu um texto sobre equações de segundo grau. Terá afirmado por antecipação, ao que parece, aquilo a que, pouco mais tarde, entre o séc. IX-X, o sábio egípcio Abu Kamil irá proceder: as proposições euclidianas devem poder transcrever-se em expressões numéricas.

Abu Kamil, considerado o homem da segunda geração da Álgebra, converterá em expressão algébrica a proposição 6 do Livro II de Euclides.

Assim se percebe como partem de um preconceito eurocêntrico afirmações como a de Stedall, de que Bombelli a Vieta seriam os primeiros a ligar a Álgebra à Aritmética de Diofanto e que Vieta teria sido o primeiro a a perceber que a Álgebra se poderia aplicar a problemas de Geometria ${ }^{20}$. Abu Kamil parece ser o primeiro matemático a usar e aceitar, de modo sistemático, números irracionais como solução e como coeficientes de equações.

Soluções com números negativos, porém, só no séc. XII se irão encontrar, graças à Matemática indiana, com a fórmula de Bhaskara.

\footnotetext{
18 Eves 1990: 179.

19 Hodgkin 2005: 110.

20 Stedall 2003: 6.
} 
Numa fase da história em que o mundo islâmico e o cristão se fecham e radicalizam, o monge e erudito bizantino Máximo Planudes (séc. XIII-XIV) parece, segundo Heath ${ }^{21}$, ter trabalhado com manuscritos de Diofanto, escrevendo pequenas notas ao texto (escólios).

O Renascimento redescobre Diofanto, com entusiasmo, desconhecendo substancialmente a riqueza dos caminhos da Matemática a partir da Casa da Sabedoria e o trabalho islâmico de preservação e estudo dos matemáticos gregos, de síntese e de expansão, decorrentes do confronto de métodos e de sistemas, de aprofundamentos daí decorrentes.

É expressivo o entusiasmo provocado pela descoberta de manuscritos gregos em Veneza, por parte do já citado sábio alemão Regiomontanus (latinização do nome da terra do erudito: Königsberg) - entusiasmo expresso pelo sábio numa carta a um amigo, em 1462, ou entusiasmo manifestado em 1570 pelo italiano Bombelli no prefácio da sua Álgebra, ao encontrar manuscritos de Diofanto na Biblioteca do Vaticano.

Terá Bombelli traduzido Diofanto para latim? É bem provável, mas se, por acaso, o fez, não publicou a sua tradução. Há-de ser um catedrático de Filosofia de Heidelberg, de nome Wilhelm Holzberg, quem o fará, um ano depois, em 1571. No entanto, é bem provável que a sua tradução se tenha perdido 22 .

Meio século mais tarde, em 1621, o jesuíta Bachet de Méziriac virá a publicar uma edição bilingue (grego-latim) dos seis livros de Diofanto. Esta tradução e edição parecem não ser muito cuidadas, mas ficaram, no entanto, célebres na História da Matemática. É que o exemplar encontrado contém anotações manuais, à margem, do punho do matemático Fermat, de comentário a Diofanto, anunciando que havia descoberto uma demonstração de um passo da Aritmética, mas que o espaço, na edição, era escasso para escrever ${ }^{23}$.

${ }^{21}$ Heath 1885: 38.

22 Heath 1885: 44-50 dá conta de testemunhos díspares: Nesselmann, em 1842, afirma num livro de sua autoria nunca ter encontrado uma cópia; H. Suter 1873, History of Mathematical Sciences, Zürich, afirma que a tradução é pobre, pois o autor era pouco versado em Matemática.

23 Heath 1885: 51. 
Deste modo, graças ao matemático alexandrino, Fermat encontrou as suas soluções para a formulação do que ficou conhecido como 'o último Teorema de Fermat'. Entre um e outro, a Álgebra ganhou autonomia no mundo islâmico para vir a ser recebida por culturas posteriores.

Conforme notou Hodgkins, em comentário já assinalado, é um erro a leitura eurocêntrica que faz do Renascimento o herdeiro directo da ciência grega.

Um universo se interpõe, que herdou e enriqueceu essa herança grega. Não deixa de ser expressivo este arco entre Diofanto e Fermat. E a leitura de Fermat é possível por esse caminho percorrido entre um e outro e que faz parte da tradição recebida pelo segundo.

\section{EM CONCLUSÃo:}

Depois de tudo o que até aqui foi apresentado, há que reconhecer:

o notável valor e papel de Diofanto, nas encruzilhadas da ciência entre Oriente e Ocidente;

mas, precisamente por isso, e fazendo o exercício de uma leitura não-eurocêntrica, há que deixar a pergunta: Diofanto pai da Álgebra ou, mais precisamente, Diofanto precursor da Álgebra ${ }^{24}$ ?

24 Veja-se Merzbach-Boyer 2010: 161. Os autores chamam a atenção, com toda a pertinência, para o lugar de Diofanto no longo caminho que a Álgebra há-de percorrer: "Diophantus is often called father of algebra, but we shall see that such designation is not to be taken literally. His work is not at all the type of material that forms the basis of modern algebra..." 
(Página deixada propositadamente em branco) 


\title{
DiósCórides RENOVADO PELA MÃo DOS HUMANISTAS: OS COMENTÁrios DE AMATO LUSITANO
}

\author{
Dioscorides Renewed by the Humanists: \\ Amato Lusitano's Commentaries
}

António Manuel Lopes Andrade
Universidade de Aveiro

\section{RESUMO}

O médico João Rodrigues de Castelo Branco, nome de baptismo do cristão-novo mais conhecido como Amato Lusitano, integra de pleno direito o grupo dos humanistas europeus que, nos séculos XV e XVI, dedicou o seu labor ao estudo do tratado De materia medica de Dioscórides, publicando dois livros, em fases distintas da sua vida, devotados ao comentário desta obra matricial: o Index Dioscoridis (Antuérpia, 1536) e as Enarrationes (Veneza, 1553). Apresenta-se uma reflexão sobre o texto e o contexto dos dois livros que Amato Lusitano publicou sobre o tratado grego, com o objectivo de fazer o seu enquadramento no âmbito do humanismo médico europeu e de evidenciar as condições particulares que proporcionaram ao médico português o ensejo de inscrever o seu nome na galeria dos comentadores de Dioscórides.

PALAVRAS-CHAVE: Dioscórides; Amato Lusitano; Materia Medica; Humanismo Médico

\section{ABTRACT}

The physicist João Rodrigues de Castelo Branco, the birth name of the New Christian more commonly known as Amato Lusitano, has rightly been counted among the European humanists who, in the course of the 15th and 16th centuries, have laboriously devoted themselves to the study of Dioscorides' treatise De materia medica. At distinct stages of his life, he published two works which commented on Dioscorides' seminal work: the Index Dioscoridis (Antwerp, 1536) and the Enarrationes (Venice, 1553).

We propose a reflection on the text and context of Amato Lusitano's works pertainig to the Greek treatise, so as to place them in the framework of the European medical humanism and highlight the particular conditions that made it possible for the Portuguese physicist to inscribe his name among those of Dioscorides' commentors.

KEYWORDS: Dioscorides; Amato Lusitano, Materia Medica; Medical Humanism 
Dioscórides escreveu por volta de meados do século I d. C. o tratado

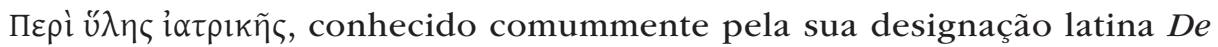
materia medica, uma obra matricial no âmbito da Medicina e da Farmácia desde a Antiguidade Clássica até ao Renascimento, porquanto os cinco livros em que se divide constituem um verdadeiro catálogo descritivo das substâncias com propriedades medicinais de origem animal, mineral e sobretudo vegetal. ${ }^{1}$ Esta obra conheceu ao longo dos séculos uma tradição manuscrita riquíssima e uma difusão a todos os títulos extraordinária (latina e árabe) em razão da enorme utilidade que sempre lhe foi reconhecida, mormente no âmbito da farmacologia.

O aparecimento da imprensa propiciou a publicação em letra de forma da antiga versão alfabética latina com as glosas que o médico Pietro d'Abano havia composto nos primeiros anos do século XIV, no quadro do seu magistério na Universidade de Pádua (Colle di Val d'Elsa, 1478). ${ }^{2}$ No entanto, malgrado esta primeira impressão ainda no curso da tradição latina medieval, o interesse pela obra de Dioscórides apenas viria a recrudescer no final do século XV, após a notável publicação da primeira edição em língua grega do De materia medica, saída dos prelos venezianos de Aldo Manuzio, em 1499. Esta edição singular constituiu, sem dúvida, um autêntico marco de viragem no estudo e na divulgação do tratado grego, porquanto colocou a obra de Dioscórides no centro do interesse e da atenção dos mais reputados humanistas e homens do saber. Ao longo do século XVI, sucedem-se por toda a Europa as edições, traduções e comentários do tratado grego a um ritmo verdadeiramente impressionante, favorecidos pela ampla generalização da imprensa e pela rápida evolução das técnicas e

${ }^{1}$ Este trabalho foi desenvolvido no âmbito do projecto de I\&D "Dioscórides e o Humanismo Português: os Comentários de Amato Lusitano" (http://amatolusitano.web.ua.pt) do Centro de Línguas e Culturas da Universidade de Aveiro, financiado por Fundos FEDER através do Programa Operacional Factores de Competitividade - COMPETE e por Fundos Nacionais através da FCT - Fundação para a Ciência e a Tecnologia, no âmbito do projecto FCOMP-01-0124-FEDER-009102. A edição crítica de referência do tratado de Dioscórides continua a ser a de Wellmann, M. (1906-1914), Pedanii Dioscuridis Anazarbei De materia medica. Berolini, 3 vols.

${ }^{2}$ Para uma relação pormenorizada das versões e comentários do tratado de Dioscórides na Idade Média e no Renascimento, cf. Riddle, J. M. (1980), "Dioscorides", in F. E. Kranz - P. O. Kristeller (eds.), Catalogus translationum et commentariorum. Mediaeval and Renaissance Latin Translations and Commentaries. Washington D. C., vol. IV, 1-143. 
métodos utilizados no processo editorial. Surgem em múltiplos formatos novas edições do texto grego, inúmeras traduções tanto em latim como em várias línguas vernáculas, acompanhadas com frequência de profusos comentários, por vezes publicados de forma independente.

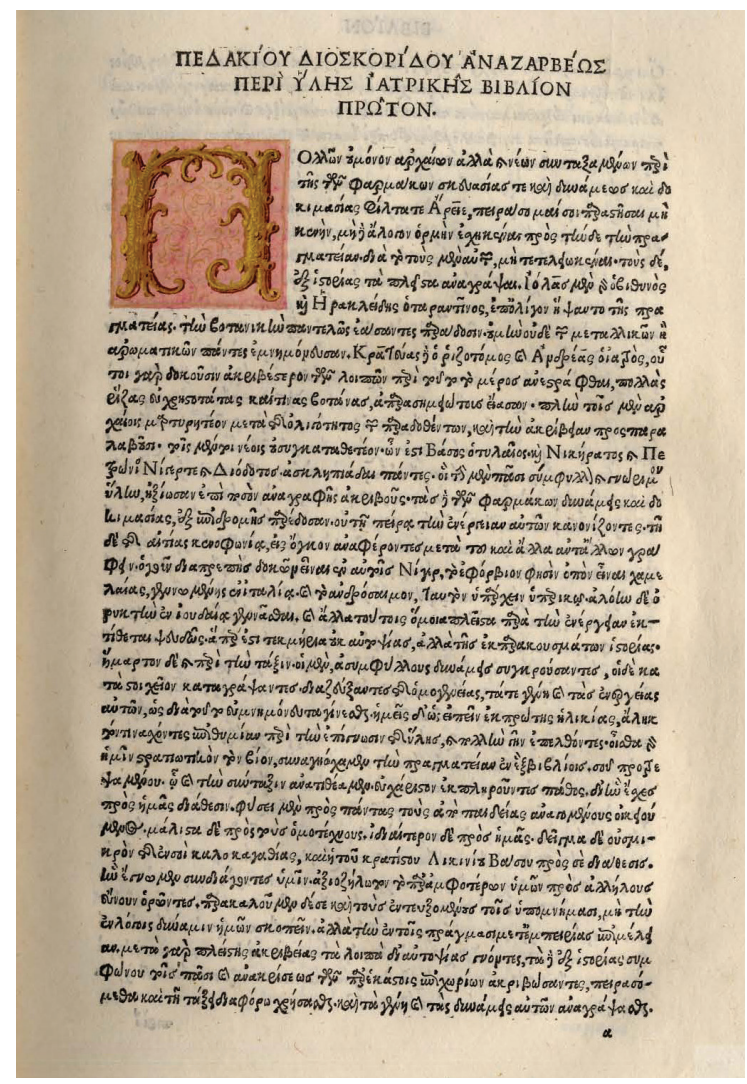

Figura 1 - Abertura da $1^{a}$ edição em grego de Dioscórides (Veneza, 1499) Biblioteca General Histórica de la Universidad de Salamanca (BG/I. 41)

$\mathrm{Na}$ verdade, os humanistas entregaram-se afanosamente ao projecto matricial de recuperação dos antigos textos gregos através da edição e, não raras vezes, da tradução dos mesmos tanto para latim como para as línguas vernáculas, convencidos da superioridade absoluta deste método eminentemente filológico na busca do saber que estava inscrito nessas obras. Os médicos humanistas procuraram, naturalmente, reformular 
a teoria e a prática da arte médica de acordo com as novas leituras e interpretações dos textos originais, as únicas que reputavam como fidedignas. Na viragem do século XV para o XVI, acentuou-se o movimento de recuperação das obras da medicina greco-latina, ganhando forma uma reacção cada vez mais intensa contra a medicina escolástica medieval, em particular contra os autores árabes, acusados tantas vezes pelos médicos humanistas de terem corrompido e deturpado a verdadeira interpretação dos textos gregos.

$\mathrm{Na}$ última década do século XV, este movimento ganha forma em Ferrara, o principal baluarte da polémica contra os Árabes em Itália ${ }^{3}$, com a publicação da obra De Plinii et aliorum in medicina erroribus (Ferrara, 1492) de Nicolò Leoniceno (1428-1524), que vem pôr em causa não só a autoridade do próprio Plínio face a autores gregos como Dioscórides, mas também de Avicena por manifestos e perniciosos erros de compreensão da terminologia botânica e anatómica gregas. ${ }^{4}$ A controvérsia desencadeada pelo humanista italiano, mormente por ter posto em causa a autoridade de Plínio, estende-se depressa aos mais importantes centros científicos europeus, ao mesmo tempo que avançava, em grande medida graças ao seu próprio labor, a redescoberta e a edição dos textos nucleares da medicina grega, nomeadamente da obra de Dioscórides, Galeno ou Hipócrates. Coube precisamente a Leoniceno um papel fundamental tanto na preparação das edições aldinas de Aristóteles (1495-1498) e de Dioscórides (1499) como de Galeno (1525).

3 Sobre o protagonismo da Escola Médica de Ferrara, projectada pela mão experiente do reputado Leoniceno e prosseguida pelos seus brilhantes discípulos Giovanni Manardo e Antonio Musa Brasavola, cf. Nutton, V. (1997), "The Rise of Medical Humanism: Ferrara, 1464-1555", Renaissance Studies: Journal of the Society for Renaissance Studies 11, n. ${ }^{\circ} 1$ : 2-19. Uma caracterização das quatro gerações de naturalistas, iniciada por Leoniceno, no período compreendido entre as décadas de 1490 e de 1620 , foi traçada por Ogilvie, B. W. (2006), The Science of Describing: Natural History in Renaissance Europe. Chicago, 25-86.

${ }^{4}$ Para uma análise pormenorizada sobre a recepção da obra de Avicena no Renascimento, cf. Siraisi, N. (1987), Avicenna in Renaissance Italy: the Canon and Medical Teaching in Italian Universities after 1500. Princeton (em particular o capítulo intitulado "The Canon in the Medieval Universities and the Humanist Attack on Avicenna”, pp. 43-76). 
aut aliquíto foztus quá certe adbuc fecilfe videris cỏuelléda. Glale. 5 to

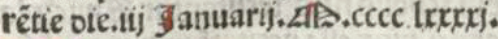

TAicolai leoniceni oc plinii z pluriú aliozus in medicina errozibus tiv ber ad ooctifimu virum Angelum TPolitianus.

\section{Zludeo plurinus angele vir ooctif}

7.25 ' fime ftudium meum in refellenda infatia barbarop iqui oe me -'dicina feripferunt abf te nunquä fatis laudato viro probari. 1 1月ó enim ego id oe te fentio quod fozte pleriq qui $^{\mathrm{i}}$ ea bereft funt boiem elo quentê nỏ poff́c oe alijs oifciplinis iudicá quafi eap peritia carere fit ne ceffariú ei qui bonaruz litterą ac politiozis bumanitatis ftudijs fuerit in

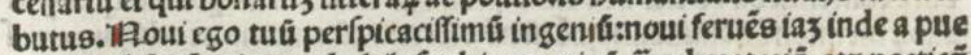
ritia ftudiá nỏ minus ad pbilofopbie ooctrinäı capé́cendā in qubuf oibus tantú pzofecifti. vt tua te patzia inclyta flo

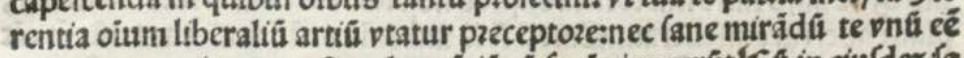

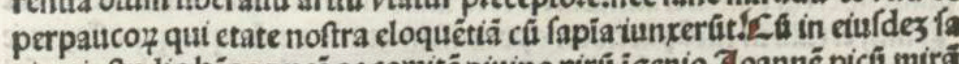

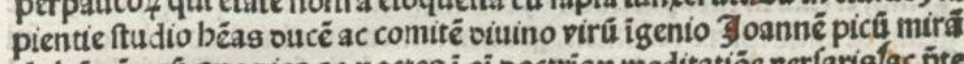

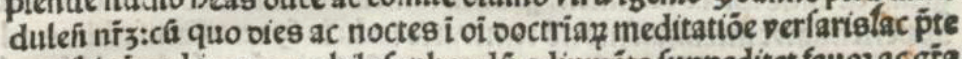
rea tibi oia ad ingenue pbilofopbandí adiuméta fuppeditet fauoz ac gía Laurêtii medicé marimi ac têpeftate ftudioz patronit:qui miffis per vni uerfum terraz ozbem nuncijs in oi of ciplinay genere libzos fumma ope conquirit:nulli fumptui parcit:quo tibi ac reliquif pzeclaris ingenijs bos

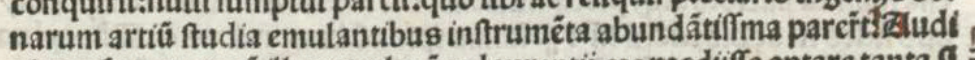
ui te referente vocé illaz pzeclarä ex laurentij oze prodúffe optare tanta fi bi abs te ac pico noftro ad libros emédos ṕftari incitamétg vt tandé oefi $C$ cientibus fumptıb? totä fuppellectılê opignerare cogatur: Cum igie oía zanimi $r$ fortune bona i te cumulatifima fint nibil eft quod angelo po litiano pro me contra barbaros pzon fiçante quépiaz ocinceps timere ve beâ:qui illop̧ patrociniñ fit fufceptur? Quod autể vt iure a me barbaros repzebêdi iudicant ita nó approbaf $q$ pliniũ oe vita ac litteris optime me ritum intra eandes cum barbaris aleă pofuerim:cuius táta fit apud peri tifitinú quemque auctozitas pt aut eâ têtare nó oebuerim aut fi omnino conuellë̉dä ourerâ fortius id a me fieri $\vec{q}$ a adbuc fecifie videar opoztuerit fi me forte bifce:perbig.vt qui mecum amice ois potes temeritatis atq is pudentie tidcite accufas:qui tante exiftimationis virus per caltiniam quo - B. $\mathbf{x}$.

Figura 2 - Abertura do livro de Nicolò Leoniceno (Ferrara, 1492) Bayerischen Staatsbibliothek, München (4 Inc.c.a. 917 d)

Na sequência da acesa controvérsia provocada pela obra De Plinii et aliorum in medicina erroribus (1492), Leoniceno passa da teoria à prática, procurando demonstrar aos seus detractores a validade científica 
do método eminentemente filológico por ele então propugnado. ${ }^{5}$ Nesse sentido, mantém uma colaboração estreita com Aldo Manuzio na edição em grego do De materia medica de Dioscórides, pondo à disposição do célebre tipógrafo veneziano os manuscritos da sua magnífica biblioteca $^{6}$ e estabelecendo muito provavelmente o próprio texto. ${ }^{7}$ Esta primeira edição em língua grega do tratado de Dioscórides constitui-se, por conseguinte, como o resultado concreto do aturado labor filológico propugnado pela medicina humanista, assente na firme convicção da superioridade deste método científico para aceder à verdade inscrita nas obras da medicina grega.

Estavam assim criadas as condições propiciadoras para o surgimento de novas versões latinas do tratado grego. Não tardaram a ser dadas à estampa as três principais versões latinas do tratado de Dioscórides da autoria de Jean Ruel (1516) e Ermolao Barbaro (publicada postumamente também em 1516 , mas realizada muito antes em 1481/2), seguidas pela de Marcello Virgilio (1518). Ao longo do século XVI, suceder-se-iam a um ritmo impressionante as edições destas traduções latinas e dos respectivos comentários, sucessivamente ampliados, seja em edições individuais ou conjuntas, seja em edições bilingues, colocando lado a lado o texto grego e a versão latina.

João Rodrigues de Castelo Branco, nome de baptismo do cristão-novo universalmente conhecido como Amato Lusitano, integra de pleno direito o grupo dos humanistas europeus que nos séculos XV e XVI mais se dedicaram ao estudo do tratado grego de Dioscórides, publicando dois livros, em fases muito distintas do seu desterro, devotados inteiramente ao comentário do tratado original: o Index Dioscoridis (Antuérpia,

\footnotetext{
5 Nas palavras esclarecedoras de V. Nutton, op. cit, pp. 3-4, "It was Leoniceno's trumpet blast in 1490 [sic] On the errors of Pliny and other doctors in medicine that provoked a Europe-wide controversy which, as every Renaissance scholar knows, dethroned Avicenna as prince of physicians and replaced him and Pliny with Dioscorides, Galen, and Hippocrates."

${ }^{6}$ Cf. Carrara, D. M. (1991), La biblioteca di Nicolò Leoniceno. Tra Aristotele e Galeno: cultura e libri di un medico umanista. Firenze.

7 Cf. Touwaide, A. (2008), "Leoniceno, Nicolò", in N. Koertge (ed.), New Dictionary of Scientific Biography. Detroit, vol. 4: 264-267.
} 
1536) ${ }^{8}$ e as Enarrationes (Veneza, 1553).9 Uma parte substancial da obra de Amato Lusitano está dedicada ao comentário do tratado grego de Dioscórides sobre a matéria médica, que foi desde os alvores do século XVI uma das obras da antiguidade mais editada, comentada e traduzida tanto para latim como para as línguas vernáculas. O médico português integra o movimento da medicina humanista iniciado por Nicolò Leoniceno, fazendo parte do conjunto dos primeiros humanistas que dedicaram o seu labor ao tratado matricial grego, sobretudo pela publicação em data recuada da sua primeira obra, o Index Dioscoridis, em Antuérpia. No entanto, teriam ainda de transcorrer dezassete anos para dar à estampa, em Veneza, o livro que lhe conferiu, decididamente, um lugar de destaque na galeria dos comentadores de Dioscórides, cujo título abreviado é In Dioscoridis Anazarbei de medica materia libros quinque...enarrationes. Através desta obra deu cumprimento cabal ao seu antigo desejo de comentar integralmente os cinco livros do tratado de Dioscórides, quando evidenciava uma experiência e um conhecimento ímpares, adquiridos ao longo da vida, desde os tempos em que frequentava o Estudo de Salamanca, dava os primeiros passos no exercício da arte de Galeno em Portugal e em Antuérpia, assistia a sua família no negócio internacional de drogas e especiarias ou exercia o seu magistério na Universidade de Ferrara, uma das escolas de medicina mais reputadas da Europa.

Uma compreensão integral dos comentários de Amato obriga, evidentemente, ao conhecimento do contexto em que estas obras surgiram e do percurso trilhado pelo médico albicastrense, com particular atenção para a acção notável desenvolvida pelos cristãos-novos portugueses em

8 Amato Lusitano (1536), Index Dioscoridis. En, candide lector, historiales Dioscoridis campi exegemataque simplicium atque eorundem collationes cum his quae in officinis habentur, ne dum medicis et Myropoliorum Seplasiariis, sed bonarum literarum studiosissimis perquam necessarium opus, Ioanne Roderico Casteli Albi Lusitano autore. Excudebat Antuerpiae vidua Martini Caesaris.

9 Amato Lusitano (1553), In Dioscoridis Anazarbei de medica materia libros quinque enarrationes eruditissimae doctoris Amati Lusitani medici ac philosophi celeberrimi, quibus non solum officinarum Seplasiariis, sed bonarum etiam literarum studiosis utilitas adfertur, quum passim simplicia Graece, Latine, Italice, Hispanice, Germanice et Gallice proponantur. Venetiis, [apud Gualterum Scotum]. 
diáspora, em que a família do próprio médico albicastrense desempenhou um papel de grande destaque. Na verdade, o facto de Amato Lusitano pertencer a uma importante família de cristãos-novos portugueses, os Pires-Cohen, chefiada pelo seu tio materno, o mercador Henrique Pires, viria a revelar-se fundamental tanto na formação como na acção do médico albicastrense, permitindo-lhe um acesso privilegiado aos meios comerciais, financeiros e culturais dos principais locais por onde deambulou (Antuérpia, Ferrara, Ancona, Florença, Veneza, Roma, Pesaro, Dubrovnik) até se ter refugiado, nos últimos anos da sua existência, nos domínios do Império Otomano, mais propriamente na cidade de Salonica. ${ }^{10} \mathrm{Na}$ primeira metade do século XVI, foram lançadas as raízes sólidas de uma estrutura alargada de base comercial, cultural e religiosa, assente em redes familiares, cujos membros se encontravam dispersos pelas grandes praças europeias. Henrique Pires constitui, precisamente, o núcleo de uma destas poderosas redes familiares cristãs-novas, em cuja órbita gravitam os vários elementos de uma extensa cadeia, ocupada pelos membros da família, de que Amato Lusitano e Diogo Pires fazem parte integrante. ${ }^{11}$

João Rodrigues de Castelo Branco é um dos ilustres membros desta rede familiar, cuja estrutura assenta na liderança incontestável de Henrique Pires. É neste contexto que devem ser perspectivados, por exemplo, a formação superior em Artes e Medicina, no Estudo de Salamanca, tanto de João Rodrigues como de Diogo Pires, ou, mais tarde, os estudos e as actividades que ambos os primos desenvolvem já em Lovaina e Antuérpia, para onde rumam por ordem de Henrique Pires pouco antes do estabelecimento do Tribunal do Santo Ofício em Portugal, em 1536. A actividade exercida pelo médico albicastrense como mercador, ao serviço do tio,

10 Para uma análise pormenorizada da constituição e das actividades da família PiresCohen, veja-se o nosso trabalho: Andrade, A. M. L. (2005), O Cato Minor de Diogo Pires e a Poesia Didáctica do séc. XVI, Aveiro (reprodução policopiada - dissertação de doutoramento), cuja primeira parte (pp. 1-134) traça um esboço biográfico de Diogo Pires e da sua família, de que faz parte Amato Lusitano.

11 Sobre a acção determinante desta figura destacada da Nação Portuguesa, cf. Andrade, A. M. L. (2010), "Pires, Henrique”, in A. Prosperi, V. Lavenia, J. Tedeschi (eds.), Dizionario storico dell'Inquisizione. Pisa, vol. III: 1225. 
à chegada ao porto do Escalda a partir do final de 1534, não pode ser dissociada, evidentemente, da sua actividade profissional e científica como médico e comentador do tratado de Dioscórides. O primeiro livro do médico albicastrense - Index Dioscoridis -, o único que ostenta o seu nome de baptismo, João Rodrigues de Castelo Branco, foi publicado, em 1536, pouco depois da sua chegada atribulada a Antuérpia, quando contava apenas com cerca de 25 anos de idade. Quando Amato aportou a Antuérpia, não detinha um conhecimento muito profundo de botânica e de história natural das drogas, como ele próprio confessa no início do Index Dioscoridis. ${ }^{12}$ Dispunha, porém, de todos os recursos necessários para ampliar os seus conhecimentos. Ao porto do Escalda chegavam os navios portugueses carregados de especiarias, drogas e muitas outras mercadorias vindas dos confins do mundo conhecido. Entre os membros do consórcio luso-italiano que as adquiria por grosso, estavam o seu tio Henrique Pires e o seu primo Estêvão Pires. Amato encontrava-se, pois, numa posição verdadeiramente excepcional, porquanto estava envolvido no negócio enquanto agente do tio e podia, ao mesmo tempo, satisfazer a sua curiosidade científica. Os mercadores tinham forçosamente um saber bastante apurado sobre os produtos em que negociavam. Amato reunia, por conseguinte, excelentes condições para reunir informações e conhecimentos que lhe permitiriam aprofundar a sua investigação sobre a matéria médica. Além disso, mantinha relações privilegiadas com os representantes da Feitoria de Antuérpia ${ }^{13}$ e com os restantes compradores e vendedores, porquanto a sua própria família integrava o Consórcio da Pimenta, sendo-lhe muito fácil recolher informações ou amostras das substâncias que pretendia. Às suas mãos chegavam não só as especiarias mais vulgares, mas também as drogas mais raras, por vezes, completa-

12 Amato Lusitano (1536), Index Dioscoridis, fl. 2v. (Lib. I, Philologia 3).

13 Entre os muitos pacientes que Amato tratou em Antuérpia contam-se, por exemplo, Manuel Cirne, feitor da Casa de Portugal (Cent. I, Curat. 3), com quem estabeleceu relações de amizade (In Dioscoridis, Lib. I, en. 76), ou o próprio Burgomestre da cidade (Cent. I, Curat. 99). Para uma relação pormenorizada das relações de Amato Lusitano em Antuérpia, estabelecida a partir de elementos colhidos nas suas obras, veja-se Lemos, M. (1907), Amato Lusitano: a sua vida e a sua obra. Porto, 65-80; Idem (1927), "Amato Lusitano. Correcções e aditamentos”, Revista da Universidade de Coimbra 10: 5-12. 
mente desconhecidas, bem como os tradicionais produtos portugueses de exportação vindos da metrópole (azeite, vinho, sal, figos e passas, atum, etc.). ${ }^{14} \mathrm{E}$, convém recordá-lo, muitos destes produtos, tantos os de proveniência oriental como ocidental, mereceram sempre o maior interesse no âmbito dos estudos sobre a matéria médica, porquanto constituiam entradas independentes no tratado de Dioscórides.

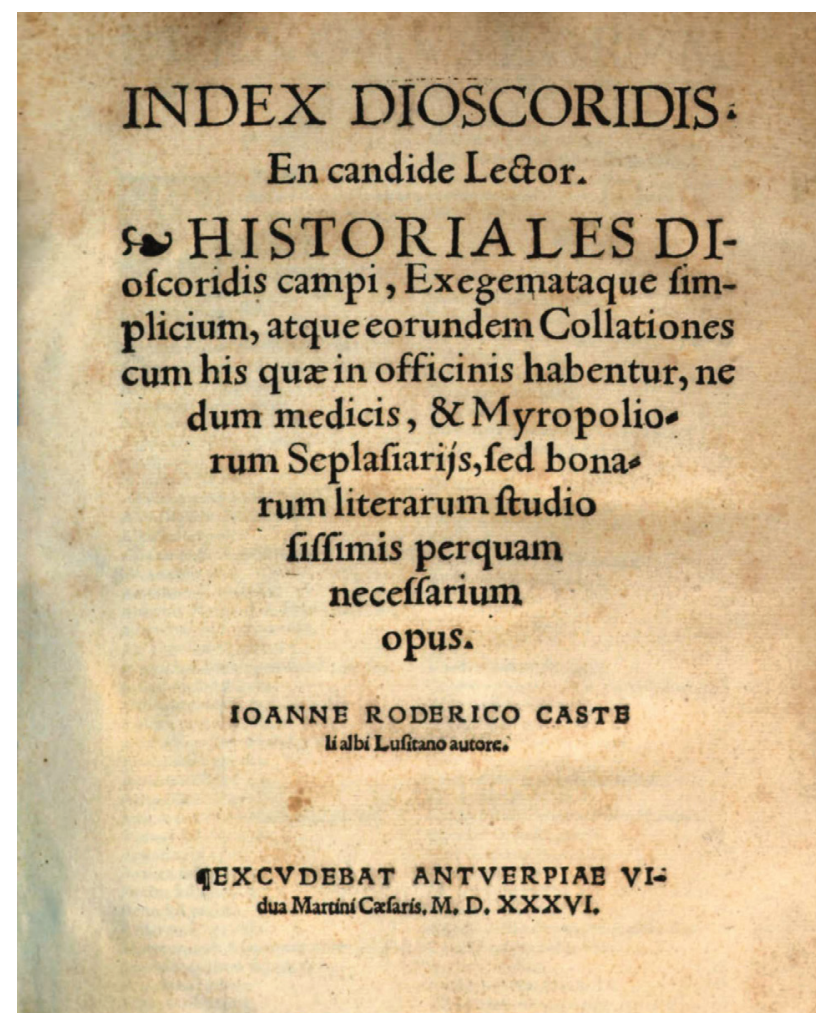

Figura 3 - Frontispício do Index Dioscoridis de Amato Lusitano (Antuérpia, 1536) Bayerischen Staatsbibliothek, München (Res/2 A.gr.b. 516)

${ }^{14}$ Amato Lusitano refere-se várias vezes nas enarrationes à exportação de produtos portugueses (figos e passas do Algarve, palmitos e atum), conforme assinala Jorge, R. (1962), Amato Lusitano. Comentos à sua vida, obra e época. Lisboa, 185-186, 196-197, 201-202. O próprio Amato, pouco tempo depois de chegar a Antuérpia, no Verão de 1535, ainda sob o nome de João Rodrigues, celebra dois contratos de afretamento com mestres da Bretanha, para a importação de figos e outras mercadorias do Algarve. Veja-se a edição dos documentos em Andrade 2010: 47-49, doc. 3 e 4. 
No entanto, malgrado a existência desta conjuntura excepcional, deve notar-se que o médico albicastrense não possuía ainda, à data da publicação do Index Dioscoridis, a maturidade necessária para comentar, conforme pretendia, o tratado de Dioscórides. Acabara pouco antes, em 1532, de obter o bacharelato em Medicina no Estudo de Salamanca, tendo depois exercido clínica em Portugal e em Antuérpia durante cerca de meia dúzia de anos; à chegada a Antuérpia, em finais de 1534, viu-se de imediato envolvido num conturbado processo judicial acusado de permanência ilegal, desrespeitando as disposições legais decretadas por Carlos V, em Agosto de 1532, que proibiam a emigração de cristãos-novos portugueses para os Países Baixos. O primo Estêvão Pires, que estava já estabelecido em Antuérpia como agente de Henrique Pires, é directamente envolvido, porque o médico albicastrense se alojou em sua casa, sendo também ele preso e impedido, com grande prejuízo, de dispor dos seus armazéns e mercadorias; no início de 1535, Amato Lusitano e Estêvão Pires são ilibados das acusações, por terem alegado estar ao serviço de Henrique Pires e por terem apresentado em tribunal uma carta de salvo-conduto, datada de 23 de Abril de 1533, concedida ao mercador Henrique Pires, ao abrigo da qual tanto ele próprio como a sua família e os feitores, servidores e procuradores da sua casa estavam autorizados a estabelecer-se e a negociar livremente em Antuérpia. ${ }^{15}$

No entanto, este primeiro livro do Index Dioscoridis, em que o médico português comenta apenas os dois primeiros livros do tratado grego, representa, desde logo, uma prova evidente do enorme interesse que Amato Lusitano manifestou desde a sua juventude pela matéria médica. Na cidade de Veneza, em 1553, veio a lume o segundo livro de comentários de Amato Lusitano a Dioscórides. Haviam passado cerca de dezassete anos desde a publicação atribulada do primeiro esboço desta obra, o Index Dioscoridis, em Antuérpia, pouco depois da chegada do jovem João Rodrigues, ao serviço do tio, ao porto do Escalda. O estudo

15 Sobre a forma como Amato Lusitano abandonou Portugal rumo a Antuérpia, onde foi acolhido por Estêvão Pires e alvo de um processo, acusado de emigração ilegal, em finais de 1534, cf. Andrade 2010: 9-49. 
e a valiosa experiência entretanto adquiridos ao longo destes anos da sua vida, muito particularmente no exercício das funções de mercador, médico e de professor na Universidade de Ferrara, concederam ao humanista português condições excepcionais para a produção de uma obra da maturidade. Cumpria-se, por fim, o ambicioso projecto de juventude do médico albicastrense, aprofundando e alargando, então, os seus comentários à totalidade dos cinco livros do tratado de Dioscórides. ${ }^{16}$

Em meados de 1540, Amato Lusitano chega a Ferrara, acompanhando a deslocação da família Pires-Cohen de Antuérpia para os domínios de Hércules II. ${ }^{17}$ No ano seguinte, o médico albicastrense inicia funções como professor de medicina teorica no Estudo de Ferrara ${ }^{18}$, onde luziu a figura excepcional de Nicolò Leoniceno, que aos 94 anos, pouco antes de falecer em 1524, ainda trabalhava afincadamente na tradução das obras de Galeno, publicadas no ano subsequente. Giovanni Manardo (1463-1536) e Antonio Musa Brasavola (1500-1555) são os discípulos do velho mestre, que dão continuidade ao extraordinário trabalho por ele desenvolvido e, em conjunto, fazem da Universidade de Ferrara uma referência incontornável no domínio da medicina e muito particularmente na investigação sobre a matéria médica. Amato Lusitano torna-se, de alguma forma, herdeiro desta tradição riquíssima, norteado pelo mesmo espírito humanista do colega e amigo Antonio Musa Brasavola, com quem se cruza no ducado de Este na década de quarenta. Este último centrou a sua actividade no estudo da botânica medicinal, aplicando rigorosamente os métodos propugnados

16 Aproveitamos o ensejo para descrever, resumidamente, os objectivos do projecto de I\&D "Dioscórides e o Humanismo Português: os Comentários de Amato Lusitano", no âmbito do qual este trabalho foi realizado. Pretende apresentar-se a edição e tradução dos dois livros que Amato Lusitano dedicou ao comentário do tratado de Dioscórides, ou seja, o Index Dioscoridis (Antuérpia, 1536) e as In Dioscoridis Anazarbei de medica materia libros quinque...enarrationes (Veneza, 1553). Além disso, está prevista a tradução de mais duas obras directamente correlacionadas com os livros do humanista português: a montante, a do próprio tratado grego de Dioscórides sobre a matéria médica; a jusante, a do livro intitulado Apologia adversus Amatbum Lusitanum (Veneza, 1558) da autoria do humanista Pietro Andrea Mattioli.

17 Cf. Leone Leoni, A. di (2011), La Nazione Ebraica Spagnola e Portoghese di Ferrara (1492-1559): I suoi rapporti col governo ducale e la popolazione locale ed i suoi legami con le Nazioni Portoghesi di Ancona, Pesaro e Venezia. Firenze, 160-161 e 703-704 - doc. 200.

18 Cf. Franceschini, A. (1970), Nuovi documenti relativi ai docenti dello Studio di Ferrara nel sec. XVI. Ferrara, 44 e 236. 
por Leoniceno, através de um cruzamento frutuoso entre a filologia e a botânica prática, centrado sobretudo no estudo local dos remédios à venda nas boticas de Ferrara. Entre 1536 e 1553, publica um conjunto de tratados, cujo objectivo principal é elaborar uma descrição dos remédios usuais em Ferrara e avaliar as suas propriedades farmacológicas, dando início a esta série com a publicação do volume consagrado aos simples, a que deu o título de Examen omnium simplicium medicamentorum quorum in officinis usus est (Roma, 1536).19

O período de Ferrara (1540-1547) revela-se fundamental na formação de Amato Lusitano, que passa a ter à sua disposição um manancial de conhecimentos, de novos contactos e de bibliografia a todos os títulos excepcional, logrando conjugar a actividade lectiva e de investigação com o exercício prático da medicina, cuja memória viva deixou gravada nas famosas Centúrias de Curas Medicinais, autênticos boletins clínicos da prática médica desenvolvida ao longo de toda uma vida. ${ }^{20}$ Este é precisamente o tempo fecundo em que o médico português começa a redigir as suas enarrationes sobre a matéria médica, mais tarde dadas à estampa em 1553. Amato Lusitano recorda esses anos dourados passados em Ferrara, considerando justamente que é o local mais indicado para quem pretende obter formação superior de re herbaria, veluti de bona medicina. ${ }^{21}$ Durante a redacção dos comentários a Dioscórides, tanto em Ferrara como em Ancona, para onde a família Pires-Cohen se deslocou por volta de 1547, Diogo Pires, talentoso poeta novilatino, manteve uma estreita colaboração com o primo Amato Lusitano. A partir do modelo clássico de Marcial, inspirado em particular nos livros dos Xenia e Apophoreta, o amigo e companheiro de desterro do médico albicastrense compõe um livrinho de epigramas, em que transforma literalmente a matéria médica em matéria poética, em resultado de um interessante e curioso cruzamento de saberes tão do agrado dos humanistas. ${ }^{22}$

\footnotetext{
19 Nutton 1997: 15-18.

20 Para uma análise pormenorizada do percurso e actividades da família Pires em Ferrara, cf. Andrade 2011: 5-16.

21 Amato Lusitano 1553: 374 (Lib. IV, en. 3: De lysimachia).

22 Andrade 2009: 345-351.
} 
Na sequência do penoso processo de falência da sociedade comercial que os Pires-Cohen haviam estabelecido formalmente com o duque de Ferrara, em 1541, os membros da família, entre os quais se encontram Amato Lusitano e Diogo Pires, começaram a deslocar-se para o estado papal de Ancona por volta de 1547, onde passaram a estabelecer a sede principal das suas actividades. A falência da sociedade com Hércules II constituiu um golpe bastante profundo em toda a organização familiar, constituindo a razão fundamental que motivou a saída de Amato de Ferrara. Não obstante o fulgor de tempos passados, os Pires não mais recuperariam totalmente das perdas avultadas que haviam sofrido. Em sentido inverso, porém, corria a projecção alcançada por Amato Lusitano e por Diogo Pires: um adquirira merecida fama enquanto médico e professor da Universidade de Ferrara, o outro enquanto poeta de eleição com obra publicada e reconhecida nos círculos humanísticos de Lovaina e Ferrara. Não se estranha, por isso, que tanto Amato Lusitano como Diogo Pires tenham alcançado rapidamente em Ancona o reconhecimento dos seus méritos nas artes em que ambos se distinguiram. A comprová-lo estão as relações privilegiadas que estabeleceram nos anos passados em Ancona, não só com vários membros da família Nobili, a quem o papa Júlio III havia incumbido da governação do estado papal, mas também com o humanista Ambrósio Nicandro de Toledo, professor de línguas clássicas, primeiro em Florença e depois em Ancona. No período em que Amato Lusitano assentou arraiais na cidade de Ancona (1547-1555) começam a vir a lume, em prelos florentinos e venezianos, as principais obras do humanista português: nos primeiros anos da década de cinquenta principia a publicação da longa série das Centúrias de Curas Medicinais (Florença, 1551) e dos Comentários a Dioscórides (Veneza, 1553).23

23 Para uma relação das edições das obras do médico albicastrense, veja-se o catálogo bibliográfico organizado por Dias, J. J. A. (2011), Amato Lusitano e a sua obra: séculos XVI e XVII. Lisboa. 


\section{IN DIOSCORIDIS}

ANAZARBEI DE MEDICA MATERIA LIBROS QVINQVE ENARRATIONES ERVDITISSIMAE DOCTORIS AMATI LVGSTANI MEDICI A C PHILOSOPHI C.EÄERRIMI, quibus non folum Officinarum Seplafia. rïs,fed bonarum etiam literarum itua - diofis utilitas adfertur, quium paffim fimplicia Grace, Latine, Italice,Hifpanice, Germa. nice, \& Gallice proponantur.

Cum-Prinilegio Illufriß. Senatus Venetiad decennium.

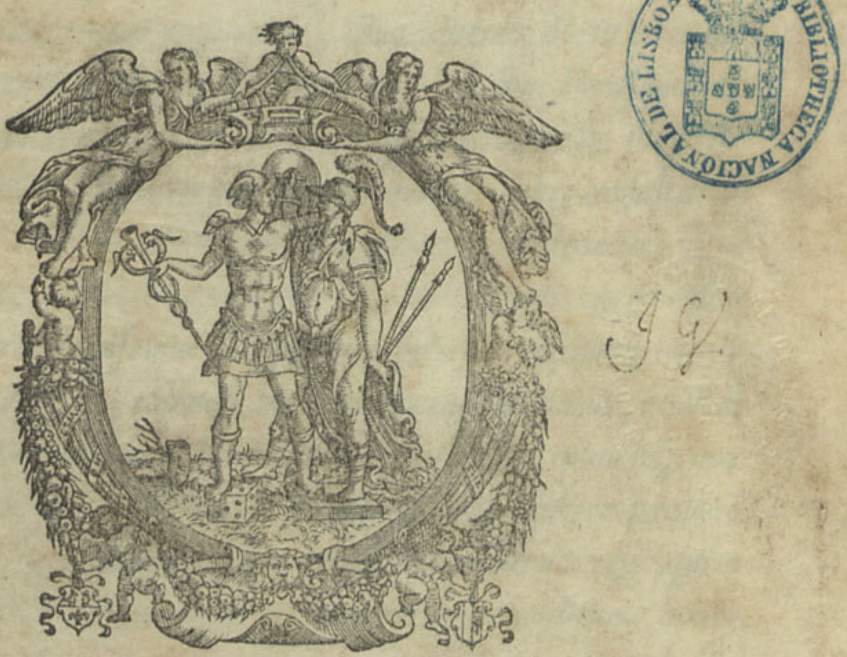

VENETIIS. MD LIII.

Figura 4 - Frontispício das Enarrationes de Amato Lusitano (Veneza, 1553) Biblioteca Nacional de Portugal (RES. 501 P.) 
A originalidade e profundidade dos comentários de Amato à matéria médica muito ficaram a dever não só ao envolvimento da sua própria família no comércio internacional, mas também aos contactos excelentes que sempre manteve, mesmo depois de ter abandonado Antuérpia e Ferrara, com todos aqueles que podiam dar notícia, muitas vezes em primeira mão, das descobertas e das novidades que afluíam à Europa, vindas de um mundo novo, cujas portas se abriam aos portugueses. Veja-se, a título de exemplo, a colaboração profícua mantida entre Amato Lusitano e Francisco Barbosa, um dos médicos portugueses pioneiros no Oriente, que regressa à Europa e convive de perto, em Ferrara e Ancona, com o colega albicastrense no período em que este redigia afanosamente os seus comentários a Dioscórides. Antes de ter chegado à Península Itálica, o cristão-novo Francisco Barbosa exerceu medicina durante 18 anos na Índia, o que ocorreu, grosso modo, durante as décadas de 20 e 30 de Quinhentos. Na enarratio dedicada ao costo (De costo), uma planta cuja identificação suscitava um aceso debate entre os comentadores de Dioscórides e de cuja existência se duvidava, Amato Lusitano declara ter visto em Ancona, pela primeira vez, raízes do verdadeiro costo, que o próprio Francisco Barbosa lhe ofereceu, trazidas por mercadores portugueses do Oriente. Amato partilha de imediato a novidade com os seus colegas e amigos mais chegados, enviando amostras da raiz para Ferrara e Veneza, nomeadamente para Antonio Musa Brasavola. ${ }^{24}$

Entre os casos merecedores de uma atenção particular, sublinha-se também o tratamento especial que é dado à pedra bezoar e ao unicórnio, duas matérias que não figuram no tratado grego original, mas que Amato Lusitano aproveitou para comentar, detidamente, a pretexto das relações estabelecidas com duas entradas originais de Dioscórides: o vergalho de cervo e o corno de cervo. ${ }^{25}$ Malgrado a atitude quase reverencial dos humanistas em relação aos textos gregos, o tratado de Dioscórides dificilmente conseguia abarcar um conjunto cada vez maior de matérias até então mal conhecidas ou completamente desconhecidas, que chegavam à Europa pela mão dos Portugueses através da rota do Cabo. É este cru-

\footnotetext{
24 Amato Lusitano 1553: 19 (Lib. I, en. 15: Costus - Falsus costus).

25 Amato Lusitano 1553: 186-188 (Lib. II, en. 39: De cervi masculi genitale); 195-197 (Lib. II, en. 52: De cornu cervi).
} 
zamento fecundo entre a segurança da antiguidade e o sobressalto da modernidade que encontramos, a cada passo, nos comentários do médico albicastrense. O valor incalculável que a pedra bezoar e o unicórnio adquiriram no século XVI, em boa parte graças às suas miraculosas e apregoadas propriedades medicinais, entre as quais se destaca o valor de antídoto contra o envenenamento por arsénico, tornava quase obrigatória a sua inclusão entre a matéria médica. Por isso, Amato Lusitano sentiu a necessidade premente de integrar nos seus comentários algumas realidades que não figuravam no tratado de Dioscórides, comentando de forma verdadeiramente original as propriedades medicinais tanto do bezoar como do unicórnio e dando início, aliás, a uma prolongada e participada discussão científica nas décadas seguintes sobre a validade do efeito medicinal e terapêutico destas substâncias. ${ }^{26}$

A década de cinquenta do século XVI marca o aparecimento de algumas das obras mais notáveis sobre o tratado de Dioscórides. Pietro Andrea Mattioli, o mais famoso tradutor e comentador de Dioscórides, começou a granjear fama com a publicação da versão italiana de Dioscórides acompanhada de comentários (Veneza, 1544), que foi aumentando e melhorando nas edições seguintes. Um ano depois da publicação das enarrationes de Amato Lusitano, o médico de Siena dá à estampa a edição latina dos seus comentários, ilustrada pela primeira vez com gravuras e bastante ampliada e melhorada em relação às anteriores, fazendo-a acompanhar da versão latina de Jean Ruel por ele próprio revista (Veneza, 1554). Por sua vez, Andrés Laguna publica no ano seguinte a conhecida versão castelhana de Dioscórides também acompanhada de profusos comentários e ilustrada com gravuras (Antuérpia, 1555). ${ }^{27}$

A publicação das Enarrationes de Amato Lusitano, em 1553, cedo despertou a atenção da comunidade científica, nomeadamente de Pietro Andrea

26 Sobre o tratamento dado por Amato Lusitano à pedra bezoar e ao unicórnio, cf. Fernandes - Andrade 2013: 35-40.

27 Para uma análise das relações complexas entre Amato Lusitano e Andrés Laguna, cf. González Manjarrés, M. Á. - Pérez Ibáñez, M. J. (2003), “Andrés Laguna y Amato Lusitano, el desencuentro de dos humanistas médicos": in F. Grau Codina (ed.), La Universitat de València i l'Humanisme: Studia Humanitatis i renovació cultural a Europa i al Nou Món. València, 689-711. 
Mattioli, que nesse mesmo ano, em carta dirigida a Ulisse Aldrovandi, manifestava a firme intenção de se defender das críticas que o Lusitano acabava de lhe dirigir no livro. ${ }^{28}$ No entanto, apenas respondeu às vinte calumniae de Amato, em 1558, com a publicação da Apologia adversus Amathum Lusitanum, uma autêntica diatribe contra o médico português, onde não se coíbe de o injuriar e acusar, por exemplo, de apostasia e de duplicidade religiosa, ultrapassando em muito a mera polémica científica. ${ }^{29}$

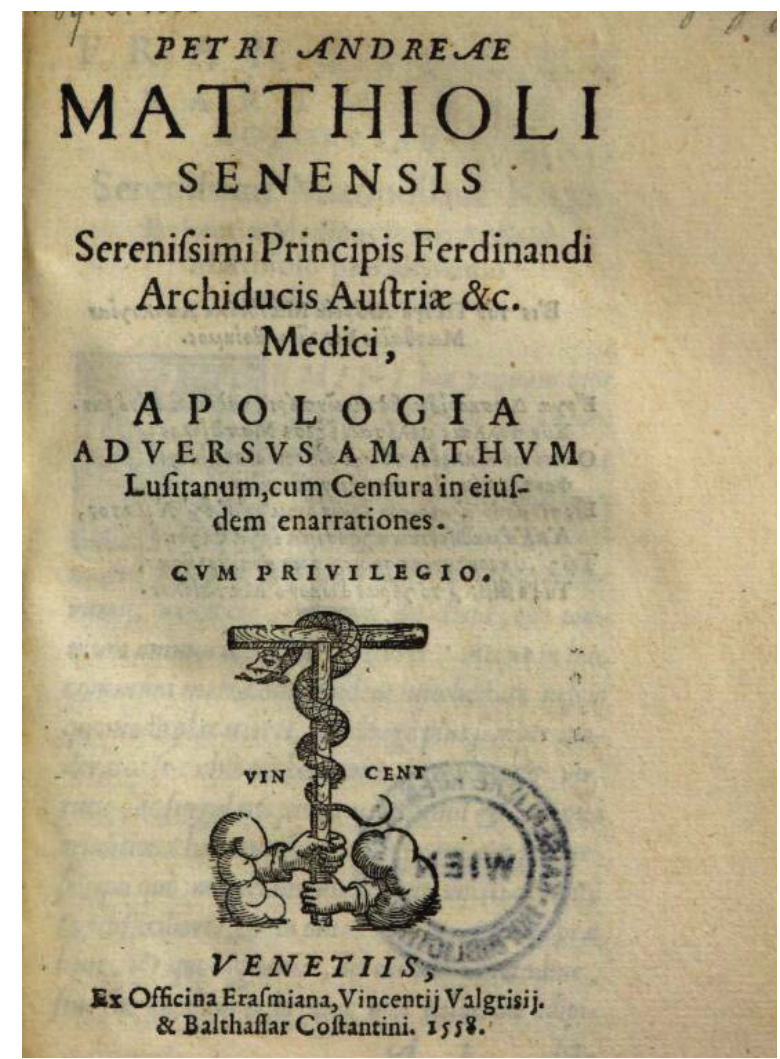

Figura 5 - Frontispício da Apologia de P. A. Mattioli (Veneza, 1558)

Österreichischen Nationalbibliothek, Wien $(* 69.0 .100)$

28 Cf. Friedenwald, H. (1937), "Amatus Lusitanus", Bulletin of the Institute of the History of Medicine 5: 622.

${ }^{29}$ A propósito da polémica entre o médico português e italiano, cf. Pinto, A. G. (2013), "Ciência e Preconceito: O ataque de Pietro Andrea Mattioli a Amato Lusitano", Humanitas 65: 157-182. 
Os autos-de-fé de Ancona, entre Abril e Junho de 1556, durante o pontificado de Paulo IV, constituíram um dos episódios mais trágicos da diáspora sefardita na Península Itálica, no qual foram martirizados cerca de três dezenas de judeus portugueses. Os comissários papais começaram por apreender, inventariar e avaliar os bens de inúmeros membros da comunidade judaico-portuguesa, entre os meses de Agosto e Novembro de 1555, pouco depois da ascensão do cardeal Carafa ao sólio pontifício. Amato Lusitano foi testemunha de parte dos acontecimentos, tendo conseguido escapar à fúria inquisidora de Paulo IV. Terá sido avisado, com alguma antecedência, dos dias difíceis que se avizinhavam para os judeus portugueses de Ancona, pelo que decidiu refugiar-se em Pesaro, escapando assim à prisão. Perdeu, no entanto, a quase totalidade dos seus bens e, nos autos-de-fé, perdeu para sempre familiares, amigos e conterrâneos, com quem tinha convivido desde sempre, em particular durante os anos da sua permanência em Ancona. A maior perda, porém, foi seguramente a do tio, Henrique Pires, uma figura marcante ao longo de toda a sua vida. ${ }^{30}$

O conhecimento das circunstâncias atribuladas que marcaram a vida do cristão-novo Amato Lusitano assume uma importância fundamental na compreensão de muitos aspectos da sua obra, nomeadamente no que toca à reacção violenta que a sua publicação provocou da parte de Pietro Andrea Mattioli. Na verdade, o médico de Siena aguardou pacientemente pelo momento oportuno para desferir o golpe fatal sobre o seu adversário, manchando para sempre o nome e a reputação de Amato com a publicação da Apologia adversus Amathum Lusitanum, primeiro em edição independente e depois acrescentada em anexo às edições latinas dos seus comentários a Dioscórides. Foi muito provavelmente esta a razão pela qual o Senado de Dubrovnik decidiu prescindir dos serviços de Amato

\footnotetext{
30 Para uma análise dos trágicos acontecimentos ocorridos no estado papal de Ancona, centrado no estudo e edição dos inventários dos bens arrolados pelos comissários pontifícios aos médicos Amato Lusitano e Francisco Barbosa e ao boticário Joseph Molcho, cf. Andrade, A. M. L. - Crespo, H. M. (2012), "Os inventários dos bens de Amato Lusitano, Francisco Barbosa e Joseph Molcho, em Ancona, na fuga à Inquisição (1555)”, Ágora. Estudos Clássicos em Debate 14.1: 45-90.
} 
Lusitano, obrigando-o a partir de novo, no final da década de cinquenta, para se estabelecer de vez em Salonica até à data da sua morte, em 1568.

Em jeito de conclusão, deve acentuar-se que os comentários de Amato a Dioscórides são um texto de uma riqueza invulgar, pois não se limitam apenas à identificação, descrição e utilização medicinal das substâncias de origem vegetal, animal e mineral que constituem a matéria médica, já que as enarrationes do humanista português estão pejadas de divagações e reflexões muito variadas. Naturalmente, à imagem dos seus contemporâneos, o médico português é herdeiro da riquíssima tradição medieval e renascentista de edições, traduções e comentários de Dioscórides, de que se serve largamente nos seus comentários. No entanto, a formação e o percurso singular do humanista português, integrado na acção e movimentação da família Pires-Cohen e da própria Nação Portuguesa, em diáspora, propiciaram com alguma frequência as condições para o surgimento da novidade nas suas obras, tal como procurou aqui demonstrar-se através de alguns exemplos relevantes.

Os comentários de Amato Lusitano, cujo primeiro esboço é publicado quase à sua chegada a Antuérpia, inserem-se claramente no movimento humanista de regresso à pureza dos textos matriciais da Antiguidade Clássica, de que o tratado de Dioscórides é um exemplo paradigmático. São textos de carácter muito diversificado que não se cingem apenas ao âmbito estritamente filológico, porquanto constituem, no seu todo, uma manifestação significativa da contribuição decisiva dada pelo Humanismo Português para a revolução cultural e científica que, nos séculos XV e $\mathrm{XVI}$, abalou as estruturas da sociedade europeia e rasgou as fronteiras do mundo conhecido, abrindo as portas à modernidade. 


\section{BIBLIOGRAFIA}

Andrade, A. M. L. (2009), "A mundividência de Diogo Pires à luz da colectânea poética dos Xenia", in F. Oliveira, C. Teixeira, P. B. Dias (coords.), Espaços e Paisagens: Antiguidade Clássica e Heranças Contemporâneas. Vol. 2. Línguas e Literaturas. Idade Média. Renascimento. Recepção. Coimbra, 345-351.

(2010a), "Ciência, Negócio e Religião: Amato Lusitano em Antuérpia", in I. O. Castro, V. Anastácio (coord.), Revisitar os Saberes - Referências Clássicas na Cultura Portuguesa do Renascimento à Época Moderna. Lisboa, 9-49.

(2010b), "Pires, Henrique", in A. Prosperi, V. Lavenia, J. Tedeschi (eds.), Dizionario storico dell'Inquisizione. Pisa, vol. III: 1225.

(2011), "De Antuérpia a Ferrara: o caminho de Amato Lusitano e da sua família", Medicina na Beira Interior. Da Pré-História ao séc. XXI - Cadernos de Cultura 25: 5-16.

Andrade, A. M. L., Crespo, H. M. (2012), "Os inventários dos bens de Amato Lusitano, Francisco Barbosa e Joseph Molcho, em Ancona, na fuga à Inquisição (1555)”, Ágora. Estudos Clássicos em Debate 14.1: 45-90.

Aristoteles, Aristotelis qui ferebant librorum fragmenta. Collegit V. Rose. Teubner. Lipsiae, 1886.

Bertermann, W. (1913). De Iamblichi Vitae Pythagoricae fontibus. Regimonti: Ex officina Hartungiana. Königsberg.

Boas, G. (1948), 'The Role of Protophilosophies in Intellectual History', Journal of Philosophy 45: 673-684.

Boeckh, A. (1819), Philolaos des Pythagoreers Lehren nebst den Bruchstücken seines Werkes. Vossische Buchhandlung. Berlin.

Burkert, W. (1972), Lore and science in ancient Pythagoreanism, transl. A. L. Minar Jr., Cambridge University Press. Cambridge.

Burnet, J. (1908), Early Greek Philosophy. Adam and Charles Black. London.

Carrara, D. M. (1991), La biblioteca di Nicolò Leoniceno. Tra Aristotele e Galeno: cultura e libri di un medico umanista. Firenze.

Casertano, G. (2009), I presocratici. Carocci. Roma.

Centrone, B. (1996), Introduzione ai Pitagorici. Laterza. Bari, Roma.

Cherniss, H. (1935), Aristotle's Criticism of Presocratic Philosophy. Johns Hopkins Press. Baltimore.

(1944), Aristotle's Criticism of Plato and the Academy. Johns Hopkins Press. Baltimore. (1951), 'The Characteristics and Effects of Presocratic Philosophy'. Journal of the History of Ideas 12.3: 319-345. 
Cornelli, G. (2013), In Search of Pythagoreanism. DeGruyter. Berlin.

Cornelli, G.; McKirahan, R.; Macris, C. (Orgs.) (2013), On Pythagoreanism. DeGruyter. Berlin.

Cornford, F. M. (1922), "Mysticism and Science in the Pythagorean Tradition", Classical Quarterly 16: 137-150.

___ (1923), "Mysticism and Science in the Pythagorean Tradition", Classical Quarterly 17: 1-12.

Craik, E. (1995a), "Hippokratic Diaita", in J. Wilkins, D. Harvey and M. Dobson (eds.), Food in Antiquity. Univ. Exeter Press. Exeter, 343-350.

(1995b), "Diet, Diaita and Dietetics", in A. Powell (ed.), The Greek World. New York, London, 387-402.

Delatte, A. (1922), Essai sur la politique pythagoricienne. Liège, Paris.

Ducatillon, J. (1969), "Collection hippocratic, Du régime, Livre III. Les deux publics", Révue des Études Greques 82: 33-42.

Edelstein, L. (1967), "The dietetics of Antiquity", in O. Temkin and C. L. Temkin (eds.), Selected papers of Ludwig Edelstein. The Johns Hopkins Press. Baltimore, 303-316.

Eves, H. (1990, 6ªd.), An Introduction to the History of Mathematics. Pacific Grove.

Fernandes, J. S. M., Andrade, A. M. L. (2013), "A Pedra Bezoar e o Unicórnio nos Comentários de Amato Lusitano a Dioscórides: propriedades, valor, tradição e tradução", Medicina na Beira Interior. Da Pré-História ao séc. XXI - Cadernos de Cultura 27: 35-40.

Fortenbaugh W. \& Schütrumpf E. (2001), Dicearchus of Messana. New Brunswick, New York.

Franceschini, A. (1970), Nuovi documenti relativi ai docenti dello Studio di Ferrara nel sec. $X V I$. Ferrara.

Frank, E. (1923), Plato und die sogenannten Pythagoreer. Ein Kapitel aus der Geschichte des griechischen Geistes. Max Niemeyer. Halle.

Friedenwald, H. (1937), "Amatus Lusitanus", Bulletin of the Institute of the History of Medicine 5: 603-653.

Gamas, C. (2013), "A Matemática em Alexandria: Convergência e Irradiação", Revista Archai 11: 47-53.

Gigon, O. (1945), Der Ursprung der griechischen Philosophie: Von Hesiod bis Parmenides. Benno Schwabe. Basel.

González Manjarrés, M. Á., Pérez Ibáñez, M. J. (2003), "Andrés Laguna y Amato Lusitano, el desencuentro de dos humanistas médicos", in F. Grau Codina (ed.), La Universitat de València i l'Humanisme: Studia Humanitatis i renovació cultural a Europa $i$ al Nou Món. València, 689-711.

Guthrie, W. K. C. (1962), A history of Greek Philosophy, vol. I: the Earlier Presocratics and the Pythagoreans. Oxford University Press. Oxford.

Heath, Th. (1885), Diophantos of Alexandria; a Study in the History of Algebra. Cambridge. (1921, repr. 1981), A History of Greek Mathematics. Vol. II. From Aristarchus to Diophantus, New York.

Hodgkin, L. (2005), A History of Mathematics. From Mesopotamia to Modernity. Oxford.

Huffman, C. A. (1988), 'The Role of Number in Philolaus' Philosophy”, Phronesis 33.1: 1-30. (1993), Philolaus of Croton: Pythagorean and Presocratic. A Commentary on the Fragments and Testimonia with Interpretive Essays. Cambridge University Press. Cambridge. 
(2005), Archytas of Tarentum: Pythagorean, Philosopher and Mathematician King. Cambridge University Press. Cambridge.

Joly, R. (1960), Recherches sur le traité pseudo-hippocratique Du Régime. Les Belles Lettres. Paris.

(1967), Hippocrate, Du Régime. Les Belles Lettres. Paris.

Jorge, R. (1962), Amato Lusitano. Comentos à sua vida, obra e época. Lisboa.

Jouanna, J. (1995), "La naissance de l'art médical occidental", in M. D. Grmek (ed.), Histoire de la pensée médical en Occident. 1- Antiquité et Moyen Âge. Éditions du Seuil. Paris, 25-66.

(2008), "Réflexions sur le régime des peuples dans la Grèce classique (Hérodote, I, 133; Hippocrate, Ancienne médicine, ch. 5; Thucydide, I, 6) et sur le sens des mots de

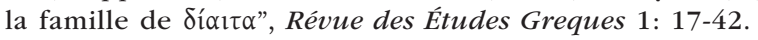

(2012), "Dietetics in Hippocratic medicine: definition, main problems, discussion", in J. Jouanna, Greek medicine from Hippocrates to Galen. Selected Papers. Translated by N. Allies. Edited with a preface by Ph. van der Eijk. Brill. Leiden, Boston, 137-153.

Katz, V. (1993), A History of Mathematics. An Introduction. New York.

Kirk, G. S., Raven, J. E., Schofield, M. (1983), The Presocratic Philosophers. 2nd edition. Cambridge University Press, Cambridge.

Klein, J. (1968), Greek Mathematical Thought and the Origin of Algebra. New York (trad. do al. de 1936).

Lemos, M. (1907), Amato Lusitano: a sua vida e a sua obra. Porto.

(1927), "Amato Lusitano. Correcções e aditamentos", Revista da Universidade de Coimbra 10: 5-38.

Leone Leoni, A. di (2011), La Nazione Ebraica Spagnola e Portoghese di Ferrara (14921559): I suoi rapporti col governo ducale e la popolazione locale ed i suoi legami con le Nazioni Portoghesi di Ancona, Pesaro e Venezia. Tomo I [-II]. A cura di Laura Graziani Secchieri. Firenze.

Lonie, I. M. (1977), "A sructural pattern in Greek dietetics and the early history of Greek medicine", Medical History 21: 235-260.

Marlowe, J. (1971), The Golden Age of Alexandria. London.

Merkelbach, U., Boyer, C. (2010, $3^{\mathrm{a}}$ ed.), A History of Mathematics, foreword by Asimov, I. New Jersey.

Nussbaum, M. (1979), "Eleatic Conventionalism and Philolaus on the Conditions of Thought", Harvard Studies in Classical Philology 83: 63-108

Nutton, V. (1997), "The Rise of Medical Humanism: Ferrara, 1464-1555", Renaissance Studies: Journal of the Society for Renaissance Studies 11.1: 2-19.

Ogilvie, B. W. (2006), The Science of Describing: Natural History in Renaissance Europe. Chicago.

Pinto, A. G. (2013), "Ciência e Preconceito: O ataque de Pietro Andrea Mattioli a Amato Lusitano”, Humanitas 65: 157-182.

Porphyrius. Porphyrii philosophi Platonici Opuscula selecta, ed. [J.] A. Nauck. Teubner, Leipzig, 1886.

Potter, P. (1988), Hippocrates. Vol V. Harvard University Press.

Raven, J. E. (1948), Pythagoreans and Eleatics. An Account of the Interaction between the Two Opposed Schools during the Fifth and the Early Fourth Centuries BC. Cambridge University Press. Cambridge (reprint Ares Publishers, Chicago, 1966). 
Rey, A. (1933), La jeunesse de la science grecque. La Renaissance du Livre. Paris.

Riddle, J. M. (1980), "Dioscorides", in F. E. Kranz, P. O. Kristeller (eds.), Catalogus translationum et commentariorum. Mediaeval and Renaissance Latin Translations and Commentaries. Washington, vol. IV, 1-143.

Siraisi, N. (1987), Avicenna in Renaissance Italy: the Canon and Medical Teaching in Italian Universities after 1500. Princeton.

Smith, W. D. (1980), "The development of classical dietetic theory", in Hippocratica. Actes du colloque hippocratique de Paris (Setembre 1978). CNRS, Paris, 439-448.

(1992), "Regimen, крп̃бıৎ and the History of Dietetics", in J. A. López Férez (ed.), Tratados Hipocráticos. VII e colloque international hippocratique. Madrid, 263-271.

Soares, C. (2012), "Receitas do mais antigo Guia Gastronómico: Iguarias do Mundo de Arquéstrato", in M. Regina Cândido (org.), Práticas Alimentares no Mediterrâneo Antigo. NEA-UERJ, Rio de Janeiro, 33-59

Speusippus of Athens. A Critical Study. Collection of the Related Texts and Commentary by L. Tarán. Philosophia Antiqua, 39. Brill. Leiden, 1981.

Stedall, J. (2003), The Great Invention of Algebra. Thomas Harriot's Teatise on Equations. Oxford.

Tannery, P. (1887a), La geometrie grecque: comment son histoire nous est parvenue et ce que nous en savons. Gauthier-Villars. Paris.

(1887b), Pour l'histoire de la Science Hellène. De Thalès à Empédocle. Alcan. Paris.

Taylor, A. E. (1911), Varia Socratica. Oxford University Press. Oxford.

Thivel, A. (2000), "L'évolution du sens de $\triangle \mathrm{IAITA}$ ", in J. A. López Férez (ed.), La lengua científica griega. Madrid, 25-37.

Touwaide, A. (2008), "Leoniceno, Nicolò", in N. Koertge (ed.), New Dictionary of Scientific Biography. Detroit, vol. 4: 264-267.

Wehrli, F., Die Schule des Aristoteles; Texte und Kommentar (1944-1960), Heft I: Dikaiarchos (1944), Heft II: Aristoxenos (1945), Heft III: Klearchos (1948), Heft VII: Herakleides Pontikos (1953); Heft VIII: Eudemos von Rhodos (1955). Benno Schwabe, Basel, 19441955; 2te ergänzte und verbesserte Aufl. 1967.

Wilkins, J. (2005), "The social and intellectual context of Regimen II", in Ph. J. van Eijk (ed.), Hippocrates in Context. Papers read at the XIth International Hippocrates Colloquium. University of Newcastle upon Tyne 27-31 August 2001. Brill. Leiden, Boston, 121-133.

Zeller, E., Mondolfo, R. (1938), La filosofia dei greci nel suo sviluppo storico. Trad. R. Mondolfo. La Nuova Italia. Firenze.

Zhmud, L. J. (1989), “'All Is Number?' 'Basic Doctrine' of Pythagoreanism Reconsidered", Phronesis 34: 270-292.

(1997), Wissenschaft, Philosophie und Religion im frühen Pythagoreismus. Akademie Verlag. Berlin.

(2012), Pythagoras and the Early Pythagoreans. Oxford. Oxford University Press.

(2013), "Pythagorean Number Theory in Academy", in G. Cornelli, R. McKirahan, C. Macris (Orgs.) (2013), On Pythagoreanism. DeGruyter. Berlin, 308-323 
Aristóteles:

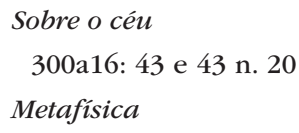

De materia medica: 72
Espeusipo:

44 A13 DK // Fr. 4 Lang: 47 e 47 n. 29

Hipócrates:

Das águas, dos ares e dos ventos

31 n. 20

Da dieta: $15 ; 17 ; 18$ n. $4 ; 27$

2: 17

2.2: 15

33-34: 30

39. $1: 20$

39.2: 20

40-85: 14 n. 2

40-55: 21

46: $23-24$

46-51: 22

47: 24

49: 23 e 23 n. 13

50: 24

51: 24

52.1: 31

56.2: $20 ; 25$

56.4: 34

56.8: 21

58-59: 19

67.1-3: 35

68: 30

68.6: 31

68.7: 30

68.10: 30

68.13: 33

68.14: 34

70-84:18; 25

79: 26

Da dieta na saúde

14 n. 3 
Da dieta nas doenças agudas

14 n. 3

Da Medicina Antiga

3: 15 ?20: 35 n. 23

Do alimento

14 n. 3

32: 35 n. 23

Do uso de líquidos

14 n. 3

Dos padecimentos: $17 ; 18$ n. 4

1: 18

39: 29

39-61: 14 n. 2

39-61: 27

40: 27

41: 27

43: 27-29

44: 29

49: 28

50: 22

50 e $61: 22$ n. 8

52: 28

54-58: 27

56. 1: 27 n. 16

61: 21 n. 6

Nicómaco de Gerasa:

Introdução à Aritmética: 63

Porfírio

Vida de Pitágoras: 19: 39 e 39 n. 2 


\section{INDEX NOMINVM}

akratos: 3 n. 21

Alexandre de Afrodísias: 48

Alexandria: 60-61; 63-65

Álgebra: 61; 64; 67; 69 e 69 n. 24

alimentação: 15; 18-19; 26; 29-30; 33

alimentos: 17-18; 20-21; 22 n. 9; 24; 26 n. 14; $28 ; 30-31 ; 35-36$

Amato Lusitano: 76-77 e 77 n.8 e n. 9; 79 n. 12 e n. $13 ; 80$ n. $14 ; 81$ e 81 n. $15 ; 82$ e 82 n. 16 ; 83 e 83 n. $21 ; 84$ e 84 n. 23 ; $85-86$ e 86 n. 24 e n. $25 ; 87-8$ e 88 n. 28 e n. $29 ; 89$ e 89 n. $30 ; 90$

Antuérpia: 79; 81; 86

Apolónio: 60

Apolónio de Perga: 60

archai: $44 ; 47$

Arcturo: 33

Aristarco de Samos: 61

Aristóteles: 39 e 39 n. 3; 40-45; 47-58; 76 n. 6

Aristoxeno: 48

arithmos: 46-47; 64

Arquéstrato: 23 n. 13

Arquimedes: 60

Arquitas: 45; 55; 57

asthenea: 22

astronomia: 63

autos-de-fé: 89

Avicena: 74 e 74 n. 4

Babilónia: 62

biodiversidade: 35

Bitínia: 61

botânica: 74; 82-83

bomoiómata: 48

califas: 65

China: 62

coito: $31-33$ cosmologia: 39

culinária: 17; 22 e 22 n. 10; 25; 27

cultos dionisíacos: 49

Demócrito: 45

diaita: $15 ; 24-25 ; 30$

Dicearco: 39 e 39 n. 3

dieta: 14-15; 18-19; $26 ; 27$ e 27 n. 17; 28 e 28 n. $18 ; 29-30$ e 31 n. 20; 32-36

dietética: $18 ; 22 ; 28$

Diofanto: 60 e 60 n. 2; 61-63 e 63 n. 12; 64-67; 69 e 69 n. 24

Dioscórides: $72 ; 72$ n. 2; 73-74; 76 e 76 n. 5; 77; 79-82 e 82 n. 16; 83; 86-87 e 87 n. 26 e n. $27 ; 89-90$

diuréticos: 20

dynameis: $18 ; 20 ; 24 ; 28$

Ecfanto: 55

Egipto: 61-62; 65

Eratóstenes de Cirene: 61

Espeusipo: 47

Euclides: 60-61; 63

Eudoxo de Cnidos: 61 n. 5;

Eurito: 44-45; 47

Europa: 62; 72; 77; 86

exercício: $14-15 ; 17-20 ; 23$ n. 12; 26-28; 30-36

Farmácia: 72

farmacologia: 72

festivais religiosos: 21

Filolau: 39-40; 47; 55; 57-58

Galeno: 74; 76 n. 6; 77; 82

geometria: 63; 66-67

Grécia: 39; 61

Gregos: 14 n 2; 22 n. 9; 63-64

hábitos alimentares: $21 ; 29$

Héron: 60

Hipácia: 64 
Hiparco de Niceia: 61

Hipaso: 55

Hipócrates de Quios: 61 n. 5; 74

História da Álgebra: 61

História da Alimentação: 20; 26

História da Matemática: 60; 68-69

História da Medicina: 20

bygieia: 15

Idade Média: 62; 72 n. 2

Império Otomano: 78

Índia: 62

ischura: 25

laxantes: 20

Leoniceno: 74-75

Leucipo: 45

Maomé: 65

Marcial: 83

massagens: 34

matemática: 39; 41; 60; 62; 66-68

Máximo Planudes: 68

medicina: $15 ; 34 ; 72 ; 82-83$

Mediterrâneo: 33

Mesopotâmia: 62; 65

metabolismo: 35

méthexis: $48 ; 50$

metron: 16

mímesis: 48; 50; 52

monas: 64

Nicomaco: 47

Nicómaco de Gerasa: 63

nousos: 15

nutrição: $17 ; 20 ; 25$

papiro: 62

Papo: 60 n. 2

Pérsia: 65

physis/physeis: $18 ; 20$

Pitágoras: 38-39 e 39 n. 3; 48; 54-55 e 55 n. $45 ; 57$

pitagorismo: 39; 41; 49; 52; 54; 59; 63

Platão: 40; 44; 48; 61 n. 5

platonismo: 53

Plêiades: 34

Plínio: $74 ; 76$ n. 5 política: 39

ponoi: 18

Porfírio: 38

protopitagorismo: 54

pséphoi: 45

Ptolomeu: 60; 65

refeição: 33

Renascimento: $62 ; 68 ; 72$ e 72 n. 2

Romanos: 22 n. 9

saúde: 17-19

stoichéia: 44

terapêutica: $17 ; 20 ; 25$

Téon: 64

Têudio de Magnésia: 61 n. 5,

Tribunal do Santo Ofício: 78

trophe: 14 n. 2

vestuário: 34

zero: 66 


\section{ESPAÇOS DO PENSAMENTO CIENTIIFICO DA ANTIGUIDADE}

incide o seu foco sobre as origens

greco-romanas da formação da investigação científica nas áreas da Medicina e da Matemática.

Os estudos tratam, no domínio médico, da dietética hipocrática e suas relações com a história da alimentação, bem como do contributo de Amato Lusitano para o desenvolvimento da botânica médica no Renascimento; no domínio matemático, do papel da teoria dos números na filosofia pitagórica e de Diofanto como precursor da Álgebra, área que se autonomizaria no mundo islâmico. 
OBRA PUBLICADA

COMA COORDENAÇÃO

CIENTÍFICA

$\mathrm{ECH}=$ 